Florida International University

FIU Digital Commons

FIU Electronic Theses and Dissertations

University Graduate School

$3-22-2018$

\title{
The Influence of Perceived Psychological Contract Violations on Expatriate Attitudes: The Moderating Role of Individual, Organizational, and National Factors
}

Kowoon Kim

Florida International University, kkim@fiu.edu

DOI: $10.25148 /$ etd.FIDC006526

Follow this and additional works at: https:// digitalcommons.fiu.edu/etd

Part of the Business Administration, Management, and Operations Commons, Human $\underline{\text { Resources Management Commons, and the International Business Commons }}$

\section{Recommended Citation}

Kim, Kowoon, "The Influence of Perceived Psychological Contract Violations on Expatriate Attitudes: The Moderating Role of Individual, Organizational, and National Factors" (2018). FIU Electronic Theses and Dissertations. 3684.

https://digitalcommons.fiu.edu/etd/3684 


\title{
FLORIDA INTERNATIONAL UNIVERSITY
}

Miami, Florida

\section{THE INFLUENCE OF PERCEIVED PSYCHOLOGICAL CONTRACT VIOLATIONS ON EXPATRIATE ATTITUDES: THE MODERATING ROLE OF INDIVIDUAL, ORGANIZATIONAL, AND NATIONAL FACTORS}

\author{
A dissertation submitted in partial fulfillment of \\ the requirements of the degree of \\ DOCTOR OF PHILOSOPHY \\ in \\ BUSINESS ADMINISTRATION
}

by Kowoon Kim 
To: Dean Joanne Li

College of Business

This dissertation, written by Kowoon Kim, and entitled The Influence of Perceived Psychological Contract Violations on Expatriates Attitudes: The Moderating Role of Individual, Organizational, and National Factors, having been approved in respect to style and intellectual content, is referred to you for judgment.

We have read this dissertation and recommend that it be approved.

Mary Ann Von Glinow, Major Professor

Ochieng F. Walumbwa

Hock-Peng Sin

Karlene C. Cousins

Date of Defense: March 22, 2018

The dissertation of Kowoon Kim is approved.

Dean Joanne Li
College of Business

Andrés G. Gil Vice President for Research and Economic Development and Dean of the University Graduate School

Florida International University, 2018 


\section{ACKNOWLEDGMENTS}

In my long, lonely journey towards a doctoral degree, first and foremost, I would like to thank God for being my greatest source of strength. Without His grace, this achievement would not have been possible.

I am forever indebted to my advisor, Dr. Mary Ann Von Glinow, for her patient guidance and unwavering support throughout my doctoral studies. She never gave up on me and always preserved her confidence in my ability to complete this Ph.D.

I would like to express my sincere appreciation to my dissertation committee, in addition to Dr. Mary Ann Von Glinow, Dr. Ochieng Walumbwa, Dr. Hock-Peng Sin, and Dr. Karlene Cousins for helping my research greatly with their expertise and showing me the way ahead.

Finally, I would like to dedicate this work to my beloved family, especially to my parents, Mr. Ingeol Kim and Mrs. Myeonghee Choi. They have always been my biggest cheerleaders along the way and believed in me even when I doubted myself. The love and care of my sister, Sahlang Kim, and her husband, Dohyun Kim, have made a tremendous contribution in helping me reach this stage in my life. I thank them all. 


\section{ABSTRACT OF THE DISSERTATION \\ THE INFLUENCE OF PERCEIVED PSYCHOLOGICAL CONTRACT VIOLATIONS \\ ON EXPATRIATE ATTITUDES: THE MODERATING ROLE OF INDIVIDUAL, ORGANIZATIONAL, AND NATIONAL FACTORS \\ by}

Kowoon Kim

Florida International University, 2018

Miami, Florida

Professor Mary Ann Von Glinow, Major Professor

As a business becomes dependent on knowledge and intellectual capabilities, human resource management is undoubtedly a key driver of an organization's success. In the same vein, the importance of managing human resources for the multinational enterprise (MNE) cannot be overstated (Dowling, 1999; Hiltrop, 1999; Tung, 1984). Since a large number of MNEs depend on expatriates to run their global operations despite their relatively high costs, it is essential for MNEs to develop a better understanding of expatriate management. In this regard, the psychological contract has received recent attention as an underlying mechanism for managing expatriates. However, existing psychological contract studies have paid little heed to the unique contexts of expatriate employment relationships (Ng \& Feldman, 2009; Lub, Bal, Blomme, \& Schalk, 2016), which are different from domestic employment relationships. Expatriates are often exposed to more complex environments than their domestic counterparts, such as different cultures. Moreover, expatriate contracts usually involve multiple parties and are directed by various interests (Kraimer \& Wayne, 2004; Mendenhall \& Oddou, 1985). 
Therefore, the current understanding of psychological contracts in the expatriation context is not well understood. This could potentially hinder the ability to manage expatriates on international assignments. Using social exchange theory and equity theory, this dissertation seeks to explore expatriates' psychological contracts in the multicontextual nature of expatriation. More particularly, this dissertation aims to examine the effects of psychological contract violations on attitudinal outcomes in the expatriation context and also discover potential moderators of that relationship at the individual, organizational, and national levels. Using an expatriate sample, this dissertation employs two questionnaires within a two-week interval. The findings of this dissertation contribute to a clearer understanding of expatriate management by answering essential questions of what impact perceived psychological contract violations have on expatriate attitudes and how individual, organizational, and national factors influence the effects of perceived psychological contract violations. 


\section{TABLE OF CONTENTS}

CHAPTER

PAGE

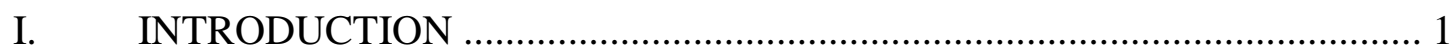

Globalization and the use of expatriates ........................................... 1

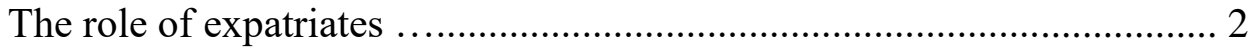

Expatriation trends ........................................................................ 4

The importance of expatriate management ........................................ 10

The psychological contract in expatriate management ......................... 13

Purpose of the study .......................................................................... 17

II. LITERATURE REVIEW AND THEORETICAL FRAMEWORK …............. 19

Psychological contract ...................................................................... 19

Motivation theory .......................................................................... 22

Social exchange theory and equity theory .......................................... 24

The effects of psychological contract violation in the expatiation context 26

The moderating role of individual factors between perceived violation in the psychological contract and expatriates' attitudes ........................... 34

The moderating role of organizational factors between perceived violation in the psychological contract and expatriates' attitudes ............................ 44 The moderating role of national factor between perceived violation in the psychological contract and expatriates' attitudes

III. RESEARCH DESIGN AND METHODOLOGY ........................................ 57

Sample and data collection ................................................................... 57

Measurements ............................................................................... 60

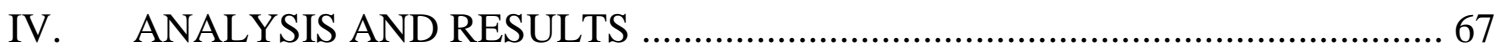

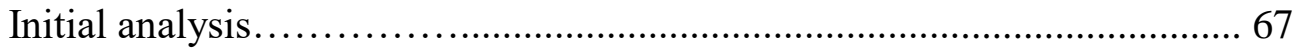

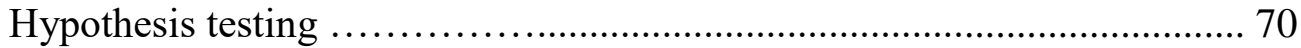

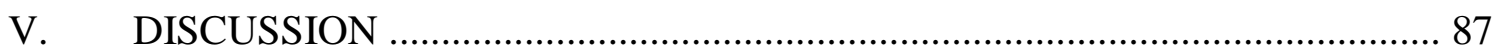

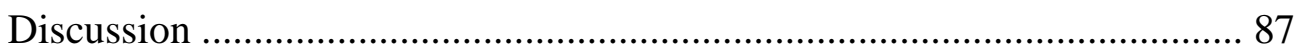

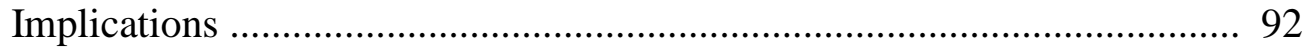

Limitations and directions for future research ....................................... 95

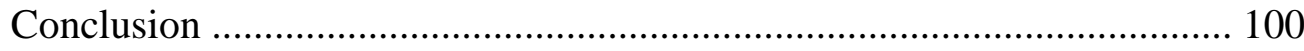

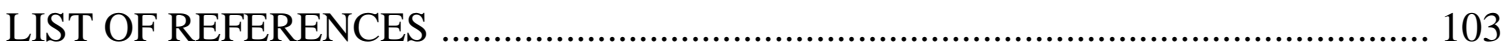

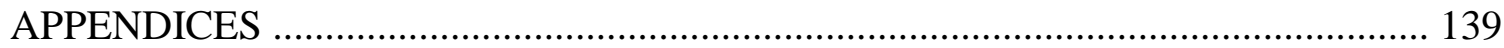

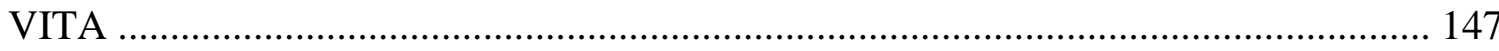




\section{LIST OF TABLES}

TABLE

PAGE

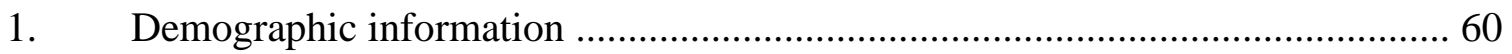

2. Correlation between the reverse score of perceived psychological contract violation and perceived psychological contract fulfillment

3. Means, standard deviations, reliabilities and correlations among all variables .... 68

4.1. Hierarchical regressions predicting the impact of perceived psychological contract violation on job satisfaction .......................................................... 71

4.2. Hierarchical regressions predicting the impact of perceived psychological contract violation on organizational commitment

4.3. Hierarchical regressions predicting the impact of perceived psychological contract violation on turnover intentions

5. A summary of research hypotheses and test results 85 


\section{CHAPTER I: INTRODUCTION}

\section{Globalization and the use of expatriates}

Over the past few decades, globalization has changed the business landscape significantly. As goods, labor, capital, and even knowledge move freely and cheaply across national borders, organizations have greater opportunities than ever before to expand their operations into global markets. Consequently, an increasing number of multinational enterprises (MNEs) have begun to appear in international business. According to a recent report (United Nations Conference on Trade and Development, 2016), there are more than 100,000 MNEs operating worldwide. In addition to large MNEs, small and medium-sized enterprises (SMEs) also have become substantially more active in global markets. As a result, the term "born global" has been coined to describe firms that seek to undertake international business operations from inception (Cavusgil \& Knight, 1996; Knight, 1996; Oviatt \& McDougall, 1994; Rennie, 1993).

With the growth of global operations, the use of expatriates has become common practice among MNEs. Indeed, the research company Finaccord (2014) estimated that there were roughly 50.5 million expatriates working worldwide in 2013 , and this figure is expected to reach 56.8 million by 2017. Furthermore, according to a Pricewaterhouse Cooper's survey (2015), 89 percent of MNEs planned to increase their number of expatriates in the next two years. Taken together, the use of expatriates in MNEs will continue to grow in response to increasing pressure for international involvement (Shen \& Edwards, 2004). 
Even though the costs of using expatriates are generally very high, they provide a variety of benefits for MNEs, including not merely filling overseas positions, but also maintaining greater corporate control over foreign subsidiaries and promoting knowledge transfer within the MNE network (Collings, Scullion, \& Dowling, 2009; Collings, Scullion, \& Morley, 2007; Edstrom \& Galbraith, 1977; Gong, 2003). These benefits can account for the continued and even increased use of expatriates in global operations. Thus, expatriate management is vital to an MNE's survival and success in today's global business environment (Konopaske \& Werner, 2002).

In recent years, increasing attention has been devoted to the psychological contract as a useful explanatory tool for understanding expatriate management. However, despite growing interest in expatriate psychological contracts, there remains a dearth of empirical research on this issue. Therefore, this dissertation aims to contribute to a more precise understanding of expatriate management by providing empirical support for the effects of expatriate psychological contracts, as well as potential moderators of psychological contract effects, including individual, organizational, and national factors.

\section{The role of expatriates}

Expatriates are generally defined as those who are sent from the parent company of the MNE to the foreign subsidiary for international assignments for two to five years, and then repatriate to their home country after completing their work assignment abroad (Caligiuri, 2000). 
As mentioned earlier, the use of expatriates allows the parent company both to fill vacancies overseas and to exercise closer or tighter control over foreign subsidiaries (Edstrom \& Galbraith, 1977). However, more recently, the goals and purposes of expatriation have been considerably diversified (Evans, Pucik, \& Barsoux, 2002). Specifically, expatriates act not only as a mere means of control over subsidiaries, but also as a means of transferring knowledge both ways between the parent company and foreign subsidiaries (Bonache \& Zarraga-Oberty, 2008; Riusala \& Suutari, 2004; Torbiörn, 1994).

Given today's knowledge-based economy, this bridging role of expatriates in knowledge transfer within the MNE network (Bonache \& Brewster, 2001; Delios \& Bjorkman, 2000; Downes \& Thomas, 2000; Harzing, Pudelko, \& Sebastian Reiche, 2016; Selmer, 2004; Tsang, 1999) has increased; expatriates do not simply transfer the parent company's knowledge to subsidiaries, but they also acquire new knowledge from subsidiaries that benefit the parent company and even the entire MNE network (Black \& Gregersen, 1999).

In short, expatriates have increasingly been recognized as organizational vehicles for knowledge dissemination beyond a unidirectional flow of knowledge from the parent company to subsidiaries (Bonache \& Zarraga-Oberty, 2008; Chang, Gong, \& Peng, 2012; Reiche, Harzing, \& Kraimer, 2009). Indeed, several studies have found that knowledge transfer is considered one of the most important expatriate functions at both the parent company and the subsidiary, whereas being an agent of direct control seems to be the least important role of expatriates (Harzing, 2001; Harzing, Pudelko, \& Sebastian Reiche, 2016). 
The compensation package of an expatriate is on average three to five times that of his or her home compensation on a yearly basis (Harzing, 2001; Reynolds, 1997). Nevertheless, MNEs continue to be highly reliant on expatriates by virtue of these essential and tactical roles of expatriates in global operations.

\section{Expatriation trends}

With the importance of expatriates in MNEs, the nature of expatriation has changed exponentially over recent decades. First and foremost, the expatriate population has been undergoing steady changes; the global workforce has been changing consistently. Expatriates, commonly called parent country nationals (PCNs), are in general predominantly from the country where the MNE is headquartered. Nowadays, however, a substantial number of subsidiary positions are filled by host country nationals (HCNs); local employees of foreign subsidiaries. Since HCNs are already familiar with the host country culture, local language, customs, and business practices, neither expensive cross-cultural training nor the process of acculturation, which often entails cost and time, are necessary (Harzing, 2001). Thus, it is not surprising that one of the biggest advantages of employing HCNs in international assignments is lower cost in comparison to PCNs.

Moreover, as MNEs have adopted a truly geocentric approach to global staffing, the use of third-country nationals (TCNs), citizens of neither the home country nor the host country, has become fairly common in expatriate practices over the years. According to the geocentric approach, selecting the most suitable person for international assignments irrespective of his or her nationality allows MNEs to 
address staffing demands more flexibly and efficiently. In fact, recent studies have found support for the growing use of TCNs in MNEs in order to respond to the staffing challenge in a skillful way (Collings, McDonnell, Gunnigle, \& Lavelle, 2010; Harzing, Pudelko, \& Sebastian Reiche, 2016; Tungli \& Peiperl, 2009). In sum, these changes show that expatriates today are more likely to get hired based on their qualifications and abilities, no matter what their countries of origin.

Another example of notable changes in the expatriate profile is the rise of non-western expatriates, particularly those from emerging countries (Goby, Ahmed, Annavarjula, Ibrahim, \& Osman-Gani, 2002). Since many MNEs are located in developed, western countries, the vast majority of expatriates have been typically westerners. However, owing to economic growth, emerging countries have significantly expanded their organizations on a global scale, so many emerging market MNEs have begun to send their employees to overseas subsidiaries. As a result, non-westerners make up an increasing proportion of the expatriate population.

Moreover, expatriates have been selected usually from management-level employees primarily due to the managerial functions they serve in international assignments; as a consequence, they have been a fairly homogeneous group of male senior managers in their 40s or 50s. Also, most of them are married and are accompanied on the international assignment by their families (Taylor, Napier, \& Mayrhofer, 2002; Vance, Paik, \& White, 2006).

However, in recent years, MNEs have been increasingly inclined to recruit expatriates at all levels beyond management-level (Reiche, 2014). This implies not only that there is a growing demand for a wide range of skills beyond management 
jobs in international assignments, but also that employees across all levels now view international assignments as a prerequisite for subsequent career advancement in their organization (Hippler, 2009; Stahl, Miller, \& Tung, 2002; Tung, 1998). Brookfield (Brookfield Global Relocation Services, 2015) found that 43 percent of employees with international experience got promoted faster than those without such experience.

Schein (1996) labeled such individuals' desires to advance their positions within the organizational hierarchy as the external career. Along with the external career, which is objective and somewhat limited to the structured organizational context, the internal career, or the subjective and broader aspects of the career (e.g., internal marketability), could also explicate part of the increasing tendency of participation of expatriates across all levels. Thus, more employees see international assignments as an opportunity not only to achieve corporate career development, but also to enhance their skills, knowledge, and experience usually not available in domestic assignments.

As several scholars have claimed, women and minorities continue to face glass ceiling barriers to some extent that limit their participation and career advancement in international assignments (Adler, 1993; Caligiuri \& Tung, 1999; Forster, 1999; McNulty \& Selmer, 2017; Morrison \& Von Glinow, 1990; Tung, 1982). According to a new report by Brookfield Global Relocation Services (2016), female expatriates comprised one quarter of the total expatriate population in 2016. It is also noteworthy that this proportion of female expatriates has leapt from three percent in the early 1990s (GMAC, 2004). Moreover, the same Brookfield report (2016) revealed that 42 percent of expatriates were between the ages of 20 and 39, 
and 32 percent were single. There are also increasing numbers of those who fall outside the traditional category of expatriate, such as couples with no children or with elderly parents and same-sex partnerships (Gedro, 2010; Kim \& Von Glinow, 2017a, 2017b; McNulty, 2014). Besides the growing number of professionally qualified minority candidates, global awareness of equal employment opportunity and inclusive recruitment is one of the driving forces behind the increasing visibility of minorities in international assignments. Taken together, these changes clearly show that expatriate demographics would no longer remain homogeneous.

In addition to the changing demographics, there is a growing array of different types of expatriates. One such type is the self-initiated expatriate (SIE). As opposed to traditional company-assigned expatriates who are sent on the international assignment by their employers, SIEs initiate their own expatriation (Kim, Halliday, Zhao, Wang, \& Von Glinow, 2016; Suutari \& Brewster, 2000; Tharenou \& Caufield, 2010). Although the SIEs' concrete and prime aims of expatriation still remain less studied, there is no doubt that they have a higher intrinsic motivation and a greater personal interest in the international assignment, as their expatriation is personal and voluntary.

Moreover, SIEs are typically hired directly by the subsidiary of the MNE in the host country under a local contract; thus, they lack inherent connections to the parent company and often receive much less support from the parent company (Andresen \& Biemann, 2013; Carr, Inkson, \& Thorn, 2005; Crowley-Henry, 2007; Jokinen, Brewster, \& Suutari, 2008; Peel \& Inkson, 2004; Peltokorpi, 2008; Selmer \& Lauring, 2010; Suutari \& Brewster, 2000; Tharenou, 2013). Therefore, SIEs do not 
necessarily adhere to the MNE and thus are more likely to possess higher organizational mobility, moving freely from one international assignment to another. Nonetheless, a number of studies have argued that SIEs represent a significant resource for MNEs operating globally (Froese, 2012; Inkson, Arthur, Pringle, \& Barry, 1997; Mayrhofer, Sparrow, \& Zimmermann, 2008).

Alongside the growing diversity in the expatriate population, there is also diversity in types of international assignments. In particular, in addition to the wholly owned subsidiaries, MNEs have taken various forms of international involvement, varying from cross-border mergers and acquisitions to international joint ventures (Mendenhall, 2005; Schuler, Tarique, \& Jackson, 2004). These different cross-border alliances demand different types of international assignments. In this sense, another trend that is changing the nature of traditional expatriation is the rise of short-term assignments.

Specifically, a growing number of MNEs opt to adopt alternative forms of conventional long-term assignments, including short-term assignments, rotational assignments, project-based assignments, commuter assignments, and frequent flyer assignments (Collings, Scullion, \& Morley, 2007; Dowling \& Welch, 2004; Mayerhofer, Hartmann, Michelitsch-Riedl, \& Kollinger, 2004; Meyskens, Von Glinow, Werther, \& Clarke, 2009; Scullion \& Collings, 2006; Starr \& Currie, 2009; Tahvanainen, Welch, \& Worm, 2005; Welch, Welch, \& Worm, 2007; Welch \& Worm, 2006).

In fact, according to a 2016 KPMG report, 83 percent of MNEs currently offer short-term assignments that are less than one year in duration. In addition, the 
findings from a 2015 Mercer survey revealed that more than half of MNEs expected to increase the deployment of short-term assignments over the next two years.

These emerging alternatives are relatively shorter in duration and hence are less likely to be associated with the relocation, whereas traditional assignments typically involve relocating the expatriate and his or her family to the host country for a predetermined, considerable length of time (Starr \& Currie, 2009; Welch, Worm, \& Fenwick, 2003). Owing to these advantages of short-term assignments, MNEs are able to bypass some of the major obstacles for mobility.

In addition to the above-mentioned alternative forms of working internationally, technological advances enable virtual assignments that require neither traditional face-to-face meetings nor relocation (Hertel, Geister, \& Konradt, 2005; Welch, 2003). More particularly, constant improvements in communication technologies, such as email, instant messaging, online chat, and video and phone conferencing, allow units of MNEs to collaborate across national boundaries and different time zones more easily, rapidly, and even less expensively. Indeed, there is abundant evidence that cross-border virtual assignments have become a key element in today's MNEs (Cousins, Robey, \& Zigurs, 2007; Malhotra, Majchrzak, \& Rosen, 2007; Maznevski \& Chudoba, 2000; Maznevski, Davidson, \& Jonsen, 2006).

In this regard, Mayerhofer and colleagues (2004) first used the term flexpatriate to describe expatriates who are employed on more flexible international assignment arrangements. Leaving the benefits of being flexible aside, flexpatriates become more attractive to MNEs primarily in terms of reducing costs. Concretely, the relocation costs, living costs, accommodation costs, and visa-related fees for 
flexpatriate assignments are much less - or even sometimes not applicable - than those of classical expatriation. In turn, this results in a cost reduction in managing international assignments (Collings, Scullion, \& Morley, 2007; Tahvanainen, Welch, \& Worm, 2005).

These trends not only indicate that the profile of expatriate populations is undergoing significant changes, but they also reflect that MNEs are paying particular attention to cost-savings and cost-effectiveness when it comes to employing expatriates. This is because traditional expatriates on the long-term international assignments are more likely to add further cost pressures to the MNE. For example, the cost of living allowance for married expatriates and their accompanying family is many times higher than that for single expatriates. Moreover, according to a 2014 Mercer survey, the majority of expatriates on short-term assignments does not bring their family members and thereby alleviate cost concerns of MNEs.

In brief, a series of changes in the nature of traditional expatriation is mainly driven by the MNE's cost-cutting concerns. In line with this, according to the Brookfield Global Relocation Services (2016), 74 percent of MNEs reported that they were under great pressure to reduce costs of expatriates.

\section{The importance of expatriate management}

\section{From a cost perspective}

Given the long-lasting concerns about the costs of expatriates, one of the most important challenges facing MNEs nowadays is a high expatriate failure rate that comes at a price. Although there has been continuous debate on the assessment of 
expatriate failure, it is generally measured either by premature termination of international assignments or failure to achieve assignment objectives (Black \& Gregersen, 1999; Briscoe \& Schuler, 2004; Forster, 1997; Harzing, 1995; Harzing \& Christensen, 2004; Johnson, Lenartowicz, \& Apud, 2006; Scullion \& Collings, 2006). In fact, previous studies have found that 16 to 40 percent of American expatriates fail to complete their international assignment (Birdseye \& Hill, 1995; Black, 1988; Employee Benefit Plan Review, 2001; Ko \& Yang, 2011; Shaffer, Harrison, \& Gilley, 1999; Tung, 1981), and this is higher than the 12 percent U.S. average domestic turnover rate (SHRM, 2016).

Moreover, subsequent studies have also estimated that the failure rate of American expatriate managers increases to 70 percent in emerging markets (Copeland, 1985; Desatnick \& Bennett, 1978; Harzing, 1995; Holmes \& Piker, 1980; McGinley, 2008; Mendenhall \& Oddou, 1985). Further, a series of studies have revealed that nearly half of expatriates who remain for the full duration of the international assignment do not perform as well as they are supposed to (Black \& Gregerson, 2007; Caligiuri, 1997; Caligiuri, Hyland, \& Joshi, 1998; Copeland, 1985).

Not surprisingly, the costs associated with expatriate failure are substantially higher than those of domestic employees (Peng, 2013), primarily because MNEs are likely to make constant investments on a large scale in selecting, training, and compensating expatriates throughout the assignment period (Harzing, 2001). 


\section{From a human capital perspective}

Along with the direct, financial costs, indirect and non-financial costs incurred by the failed expatriation are also substantial enough to get the attention, such as diminished reputation in key strategic foreign markets and damaged relations with global business constituents (Bennett, Aston, \& Colquhoun, 2000; Dowling \& Welch, 2004; Schuler, Budhwar, \& Florkowski, 2002). Moreover, the assignment failure often causes the failed retention of expatriates and the loss of valuable human capital to competitors (Lazarova \& Caligiuri, 2001).

Today, robots, machines, and artificial intelligence are already in use in thousands of assignments around the world, especially those of manual jobs. Last year, in fact, the German sportswear MNE Adidas announced that the company is going to use machine-equipped factories to produce shoes in lieu of relying on its foreign subsidiaries as a source of supply (The Economist, 2017). In this sense, no one can deny that advances in automation impact the global labor market.

However, such technologies can hardly displace those assignments requiring higher levels of cultural sensitivity or social interaction skills, including intercultural communication and cross-cultural negotiation. In other words, the automation hardly ever replaces the certain international assignments that only humans can offer. As such, an increasing number of MNEs have realized the significance of human capital and have vied for it on a global scale. Similarly, there has been a wealth of evidence to suggest that attracting and retaining talent is one of the critical success factors in

operating globally (Beechler \& Woodward, 2009; Schuler, Jackson, \& Tarique, 2011; Stahl et al., 2012). 
In this vein, expatriates are often seen as well-trained, multilingual, and culturally knowledgeable employees who are in strong demand, particularly by MNEs (McNulty \& Selmer, 2017). Therefore, it is not an overstatement to say that the loss of expatriates due to the failed expatriation may ultimately result in the deterioration in global competitiveness for the MNE, as well as other direct and indirect costs.

In sum, given the important role of expatriates to international business, expatriate management has received a great deal of attention from both scholars and practitioners. In this regard, an emerging stream of expatriate research has examined the psychological contract as an explanatory framework to understand expatriate management (Aldossari \& Robertson, 2016a, 2016b; Bolino, Klotz, \& Turnley, 2016; Breitenmoser \& Berg, 2017; Casado \& Caspersz, 2016; De Ruiter, Lub, Jansma, \& Blomme, 2016; Farndale, Pai, Sparrow, \& Scullion, 2014; Festing \& Schäfer, 2014; Guzzo, Noonan, \& Elron, 1994; Lazarova \& Caligiuri, 2002; McNulty, 2013; Pate \& Scullion, 2009, 2016; Perera, Chew, \& Nielsen, 2016a, 2016b; Yan, Zhu, \& Hall, 2002).

\section{The psychological contract in expatriate management}

Beyond the formal and legal contract of employment, each and every employee has an informal and unofficial contract in mind with his or her organization. This ambiguous, imprecise, and elusive contract in the employment relationship is often called the psychological contract (Robinson \& Rousseau, 1994; Rousseau, 1989, 1995; Schein, 1978). 
Although the psychological contract encompasses the formal requirements or promises of employment that the formal contract also specifies, such as salaries, commissions, bonuses, and benefits, it covers a much wider scope of employment promises than the formal contract does.

Furthermore, the formal contract exists in a physical state and thereby is relatively apparent and objective. As a consequence, there is generally limited room for interpretation regarding the content and the state of the formally documented contract. On the other hand, the psychological contract is fundamentally perceptual and subjective (Rousseau, 1995, 2001). Hence, it is much more open to interpretation. In other words, each individual may have different views of the psychological contract.

To wit, a psychological contract refers to the individual's internalization or interpretation of what his or her organization has promised to offer in return for the employment (Lester, Turnley, Bloodgood, \& Bolino, 2002; Rousseau, 1995).

Just as employees evaluate the formal contract, they also determine whether the psychological contract is fulfilled (Rousseau, 2001). In this sense, the psychological contract violation refers to any sort of discrepancy between perceived and actually received inducements in exchange for the employee's contributions to his or her organization (Rousseau, 1989). Moreover, just as the psychological contract comprises an individual's perception of promises, the psychological contract exists based on the employee's perception.

Not surprisingly, a plethora of studies have found that a perceived psychological contract violation is inversely related to various work-related outcomes 
(e.g., job satisfaction, organizational commitment, trust, and organizational citizenship behaviors) and conducive to counterproductive work behaviors (e.g., turnover intentions and actual turnover) (Guerrero \& Herrbach, 2008; Robinson, 1996; Robinson \& Morrison, 2000; Robinson \& Rousseau, 1994; Turnley \& Feldman, 1999, 2000). When the perceived violation in the psychological contract occurs, for instance, employees may be more inclined to display low trust towards their employers (Pate \& Malone, 2000; Robinson, 1996).

As noted above, the psychological contract is highly subjective and idiosyncratic (Guzzo, Noonan, \& Elron, 1994; McLean Parks, Kidder, \& Gallagher, 1998; Sparrow \& Cooper, 2003). Although s/he may work in the same organization and do the same job, no employee has the same psychological contract with the organization, or evaluates the contract in the same way, nor is s/he equally influenced by it. This implies that the psychological contract is context-dependent (Conway \& Briner, 2002; Pate, Martin, \& McGoldrick, 2003). Similarly, Guest (2004, p. 549) stated:

"The context helps not only to shape the content of the exchange that forms the psychological contract but also the response to it."

In this regard, the contexts of expatriation are considerably different from those in the domestic or local employment relationship. Specifically, expatriation is a multi-faceted and multi-layered phenomenon that involves mainly three-level contexts: the individual- (e.g., the expatriate's abilities, skills, and personality traits), 
the organizational- (e.g., the parent company's policies, the subsidiary's practices, and the parent company-subsidiary relationships), and the country-level (e.g., the host country's environments and the cultural differences between home and host countries) contexts.

For example, while there are two parties to the domestic employment relationship, the employee and the organization, several parties are involved in the expatriate employment relationship. At minimum, the expatriate, the parent company, and the subsidiary are the main parties to the expatriate employment relationship. This triangular employment relationship adds further complexity to the expatriates' psychological contracts.

In particular, even though the parent company hired the expatriates for international assignments and promised to deliver certain inducements (i.e., appropriate compensation and benefits), the parent company is not necessarily the one that is in charge of delivering those promises; rather, the subsidiary is in that position. Consequently, expatriates may have a feeling of psychological contract violation when the inducements, which are promised, albeit implicitly, by the parent company of the MNE, are not delivered in the subsidiary's practices (Dawson, Karahanna, \& Buchholtz, 2013; Lavelle, Rupp, \& Brockner, 2007; Marks, 2001; Morf, Arnold, \& Staffelbach, 2014).

Along with these additional parties at the organizational level, host country cultures provide a further layer of intricacy to already complex expatriates' psychological contracts. More particularly, the international assignment is carried out in the host country and hence is invariably influenced by cultural contexts of the host 
country. In fact, a wide array of studies has postulated that host country cultures have a considerable influence on expatriation (Claus, Lungu, \& Bhattacharjee, 2011). Given the fact that the psychological contract cannot completely be free from surrounding contexts, not only the organizational contexts, but also the host country's cultural contexts must be taken into consideration when it comes to understanding the expatriates' psychological contracts.

In brief, vis-à-vis the domestic counterpart, the expatriate employment relationship is influenced by a myriad of contexts.

\section{Purpose of the study}

Considering the fact that psychological contracts vary widely depending on contexts, the effects of expatriates' psychological contracts may differ significantly from those of the domestic employment relationship (Gail Lewis, 1997). Nevertheless, there has been relatively sparse research and evidence on the effects of perceived psychological contract violation in the context of expatriation. The aim of this dissertation is to investigate the effects of perceived psychological contract violation on expatriates' attitudes.

Furthermore, only a handful of studies have examined the potential moderators in the relationship between perceived psychological contract violation and employment outcomes (Ng \& Feldman, 2009; Lub, Bal, Blomme, \& Schalk, 2016; Robinson, 1996; Robinson \& Morrison, 2000; Robinson \& Rousseau, 1994), and even fewer such studies have been done to date in the expatriation context. Given the multi-contextual nature of expatriate employment relationship, another aim of this 
dissertation is to seek to examine whether individual, organizational, and national factors moderate the relationship between perceived psychological contract violation and expatriate attitudinal outcomes.

In sum, the present dissertation attempts to answer the following research questions: 1) What impact does perceived psychological contract violation have on expatriates' attitudes? and 2) How do individual, organizational, and national factors influence the effects of perceived psychological contract violation on expatriates' attitudes? 


\section{CHAPTER II: LITERATURE REVIEW AND THEORETICAL FRAMEWORK}

This chapter provides the theoretical backdrops of the study, giving an overview of existing psychological contract literature as it relates to expatriate management.

\section{Psychological contract}

The employment generally means a contractual relationship between the employee and the employer. Specifically, the employment relationship is created by the contract, which specifies some sets of reciprocal obligations entailed by the employment relationship. This so-called formal contract is a legally binding and enforceable agreement between both parties therein and thereby is typically in written form. Employment contracts are required in many countries.

In addition to the formal contract, the psychological contract also underpins the employment relationship (Sparrow, 1996). While the term psychological contract has been in use since the 1960s, there is still much debate about the precise definition of the psychological contract (Argyris, 1960; Gibson, 1966; Herriot, 1995; Kotter, 1973; Levinson, Price, Munden, Mandl, \& Solley, 1962; Schein, 1978; Weick, 1979). The most widely agreed upon definition of the psychological contract is the individual's perceptions about what inducements the organization has promised to provide in exchange for his or her contributions to the organization (Morrison \& Robinson, 1997; Rousseau, 1989, 1995). 
Even though these perceptions are held by the individual, they are also largely shaped by the organization. To say that the perception refers to a process by which individuals select, organize, and interpret their sensory information (Robbins, Millett, \& Waters-Marsh, 2004), the organization is a main provider of such information to the individual employee. As such, the psychological contract is rooted in a series of perceived promises that are made by the organization. Taken together, the psychological contract can be seen as a set of perceived promises of future returns, in the employment relationship.

This promissory nature of the psychological contract makes it conceptually distinct from mere employee expectations that represent unilateral beliefs about what the employee will receive from the job (Conway \& Briner, 2005; Guest, 1998; Robinson, 1996; Robinson \& Rousseau, 1994; Rousseau, 1995; Sutton \& Griffin, 2004). Concretely, the psychological contract is generally inferred from implied promises, whereas the expectations are not always supported by concrete promises (Montes \& Zweig, 2009).

Additionally, the psychological contract should not be confused with employees' attitudes. Specifically, the employees' attitudes reflect the individual's relatively stable and enduring patterns of evaluation about his or her organization (Staw \& Ross, 1985). On the other hand, in the psychological contract, the focus is on the individual's psychological state towards the employment relationship. Since the state itself hardly remains static, yet is always in a state of flux depending on the circumstances, the psychological contract is more likely to change according to the contexts. 
Indeed, even though there is likely to be considerable and convincing conceptual overlap between them, the psychological contract and the employees' attitudes have been treated as two separate but interacting constructs in multiple studies. The perceived violation to the psychological contract has been considered rather as a powerful determinant of employees' attitudes in the workplace (Cullinane \& Dundon, 2006; Guest \& Conway, 2002; Seeck \& Parzefall, 2010).

As it is formulated and embedded in the individual's mind, the psychological contract usually exists in unspoken and unwritten format. Because of such implicit features, the psychological contract has not received significant attention in the management literature to date. In recent years, however, a considerable number of studies have demonstrated that the psychological contract is a sound tool for understanding the contemporary employment relationship (Conway \& Briner, 2005; Guest, 2004; Rousseau, 2001; Shore \& Coyle-Shapiro, 2003; Shore \& Tetrick, 1994; Turnley \& Feldman, 1998; Zhao, Wayne, Glibkowski, \& Bravo, 2007).

In today's fast-changing business landscape, the employment relationship continues to experience changes. In particular, as the nature of business becomes increasingly complex and dynamic, so does the employee-employer relationship. Moreover, such growing complexity and instability of employment relationship create complicated interests of both the employee and the employer. For example, the rising unemployment rate can cause increased employee expectations of job security. Furthermore, a high level of market uncertainty may lead to an organization's fondness for the use of short-term contracts. Likewise, changes in the surrounding environments have a profound impact on the nature of the employment relationship. 
Nonetheless, most formal, written employment contracts are impervious to change over the duration of an individual's employment. Such lack of flexibility often results in friction between employee and employer. In this respect, unlike the formal contract, the psychological contract is inherently in a state of constant change and renegotiation (Herriot, 1992; Schein, 1988). As such, it is capable of reflecting changing circumstances in the employment relationship.

Furthermore, as previously stated, the psychological contract can encompass as diverse a set of perceptions as the employee can come up with. In other words, the psychological contract includes every perceivable or conceivable aspect of the employment relationship (Rousseau, 1990), whereas the formal contract governs only a narrow scope of that. Consistent with this, Kotter (1973) stated that the psychological contract may have literally thousands of items in it. Therefore, the extent of the psychological contract on the employment relationship often exceeds that of formal contract (Schein, 1988).

\section{Motivation theory}

The conceptual basis of the psychological contract is largely grounded in the studies of motivation. This is because the psychological contract often acts as a significant motivator in the employment relationship. More particularly, employees are motivated and engaged at work when they receive promised rewards in accordance with the psychological contract. In brief, the psychological contract is the cornerstone of employee motivation. 
In the literature, motivation is generally defined as the psychological processes that direct, energize, and maintain behavior over time (Campbell \& Pritchard, 1976; Grant \& Shin, 2011; Kanfer, 1990; Steers, Mowday, \& Shapiro, 2004). In other words, motivation refers to the set of psychological forces that drive people to be engaged in certain behaviors (Steers \& Porter, 1991).

In line with this definition, a number of motivation theories have attempted to examine the major psychological triggers behind human behaviors. The early motivation studies, which are commonly categorized as content theories or needs theories, assume that all people are motivated or demotivated by the same factor in the same way (e.g., Alderfer, 1969; Herzberg, 2005; Maslow, 1946; McClelland, 1988; McGregor, 1957).

On the other hand, subsequent studies suggest that each person has a unique set of factors that motivates him or her. In other words, different people are differently motivated (e.g., Adams, 1965; Festinger, 1957; Kahler, 1975; Locke \& Latham, 1990; Porter \& Lawler, 1968; Vroom, 1964).

Most contemporary theories of motivation contend that although people may have similar needs, they not only prioritize these needs differently, but also have different ways of satisfying needs. Moreover, the same motivator may be effective at different times.

In short, over recent decades, an increasing number of studies have begun to place emphasis on individual differences in motivation. As a consequence, several distinct theories of motivation have been proposed, claiming that motivation is a highly individual and subjective psychological process. 


\section{Social exchange theory and equity theory}

One such motivation theory is the social exchange theory (Blau, 1964;

Eisenberger, Huntington, Hutchison, \& Sowa, 1986; Emerson, 1976; Gouldner, 1960; Homans, 1958; Thibaut \& Kelley, 1959). The social exchange theory builds on the initial assumption that all humans view their own needs and desires as paramount. Accordingly, social relationships that people make can be seen as a result of the pursuit of self-interest (Chadwick-Jones, 1976). In sum, people are motivated to create and maintain a certain interpersonal relationship in the pursuit of maximizing personal benefits while minimizing personal costs (Thibaut \& Kelley, 1959).

In many cases, personal benefits are best maximized when people behave equitably (Blau, 1964; Donaldson \& O’Toole, 2007). This indicates that social relationships are reciprocal in nature based on bilateral exchanges (Fiske, 1992). Therefore, people behave according to their beliefs that the other in the social relationship will reciprocate their behavior. These beliefs, which are known as "reciprocity" in the parlance of social exchange theory (Gouldner, 1960), help to forge mutually beneficial relationships (Jones \& Vaughan, 1990; McCulloch, 1990). Compensation and benefits are positive reciprocity examples that employers may provide in returns for employees' efforts in the employment relationship.

In summary, the desire for reciprocity forms the basis of social relationships (Chen, Chen, \& Portnoy, 2009; Cropanzano \& Mitchell, 2005; Fiske, 1992; Perugini, Gallucci, Presaghi, \& Ercolani, 2003).

In addition to reciprocity, equity theory brings the concept of equity into social relationships (Adams, 1963, 1965; Buunk \& Schaufeli, 1998; Homans, 1961). 
According to equity theory perspective, people do not simply make rational calculations of potential benefits and costs that are derived from social relationships, but they also seek to achieve a balance between those.

In practice, however, not every social relationship is reciprocal. Further, the balance of exchanges in social relationships is not always equal. As a result, social relationships that maintain reciprocal exchanges are likely to remain strong. On the contrary, social relationships that fail to achieve the equitable balance in exchanges are unlikely to be maintained. The reason is that the balance between benefits and costs of social relationships is broken (Cropanzano \& Mitchell, 2005).

The standards that people use to evaluate benefits and costs of the social relationship vary considerably from person to person. In other words, the social relationship is evaluated using the subjective cost-benefit analysis (Loewenstein, Thompson, \& Bazerman, 1989; Messick \& Sentis, 1979).

Even though both social exchange theory and equity theory have been criticized for their limited applicability to diverse pattern of social relationships, they have been increasingly used to understand modern employment relationships (Hewstone, Stroebe, Codol, \& Stephenson, 1988; Lambe, Wittmann, \& Spekman, 2001). Especially, many recent studies have adopted social exchange theory and equity theory as a theoretical basis for understanding the important role of psychological contract in the employment relationship (Barksdale \& Werner, 2001; Coyle-Shapiro \& Conway, 2005; Lester, Turnley, Bloodgood, \& Bolino, 2002; Taylor \& Tekleab, 2004; Turnley, Bolino, Lester, \& Bloodgood, 2003). 
As a perceived exchange of agreement between the employee and the employer, the psychological contract underlies the employment relationship (McLean Parks, Kidder, \& Gallagher, 1998; Morrison \& Robinson, 1997; Rousseau, 1989).

Moreover, employees evaluate the psychological contract to see if their employers have successfully conveyed promises. More particularly, employees calculate the discrepancy between what they believe they were promised and were actually given. When employees perceive that they have received less than they have been promised, a perceived violation of the psychological contract occurs.

The psychological contract mostly remains implicit, but becomes explicit when it is violated. In fact, extensive empirical studies have demonstrated that the perceived psychological contract violation can profoundly damage the employment relationship, exerting negative effects on employees' attitudes (Coyle-Shapiro \& Kessler, 2000; Lester, Turnley, Bloodgood, \& Bolino, 2002; Robinson, 1996; Rousseau, 1989; Tekleab \& Taylor, 2003; Turnley \& Feldman, 1999). Zhao and colleagues (2007), for example, found that employees' perceptions of psychological contract violation leads to an immense loss of trust.

To conclude, the significance of psychological contract violation as the key antecedent of individual and organizational outcomes deserves more attention in the literature.

\section{The effects of psychological contract violation in the expatriation context}

While the psychological contract serves a variety of functions, one fundamental function of the psychological contract is to increase predictability, 
stability, and security of future exchanges among the parties involved; thus, it reduces uncertainty within the employment relationship (Shore \& Tetrick, 1994). This is because although they are just perceived promises and thereby not legally enforceable, the employees' perceptions regarding the terms of the exchange not only make them more informed, but also foster confidence regarding the employment relationship.

The greater the uncertainty, the greater the level of confidence there must be. This is because uncertainty increases the likelihood of inequitable exchanges in the employment relationship. That is, the norm of reciprocity is likely to be broken in times of uncertainty. In this vein, the expatriation is inherently packed with uncertainties and risks for both the expatriate and the MNE (Kim \& Von Glinow, 2017b).

During the process of expatriation, expatriates face multifold problems in both their professional and personal lives. Concretely, when it comes to carrying out the international assignment in the foreign subsidiary, expatriates often experience miscommunication, misunderstanding, and even conflicts primarily due to the cultures, languages, and work practices that are different from those of the home country (Von Glinow, Shapiro, \& Brett, 2004).

Along with these challenges in the workplace, expatriates also experience major life upheavals in all aspects of daily life, including housing, spouse's career, and children's education (Tanure, Barcellos, \& Fleury, 2009). In this respect, Black and colleagues (1991, p. 292) stated: 
“Moving ... to a foreign country often involves changes in the job the individual performs and the corporate culture in which responsibilities are executed; it can also involve dealing with unfamiliar norms related to the general culture, business practices, living conditions, weather, food, health care, daily customs, and political systems - plus facing a foreign language on a daily basis."

To the MNE as well, using expatriates overseas requires a kind of plunge into uncertainty. When managing employees abroad, the MNE inevitably has much greater uncertainty than at home, largely due to the different contexts (Shapiro, Von Glinow, \& Xiao, 2007). For example, different cultural contexts often hinder effective communication, produce numerous misunderstandings, and eventually increase the level of uncertainty (Johanson \& Vahlne, 1977).

Additionally, the expatriation typically entails massive investments and costs throughout the process. However, despite such substantial investments involved, most MNEs earn only modest or meager returns on international assignments (Collings, Scullion, \& Morley, 2007; Harzing \& Christensen, 2004; Meyskens, Von Glinow, Werther, \& Clarke, 2009). This fact significantly amplifies the uncertainty associated with the expatriation.

Besides, employees selected for international assignments are generally either high performers or high potentials. In this sense, the loss of such talent as a result of expatriate failures can cause severe damage to the competitiveness of the MNE. 
Taken together, it is clear that the expatriation is a process that involves great uncertainty for both the expatriate and the MNE. Given the considerable amount of uncertainty that surrounds them, expatriates are more inclined to depend upon the psychological contract (McNulty, 2013). This is because it provides predictability and thereby boosts confidence regarding the future returns.

Concurrently, however, the uncertainty emanating from the expatriation often makes it difficult for the MNE to meet all promises perceived by the expatriate (McLean, Parks, \& Kidder, 1994). This fact may in part account for the frequent occurrence of perceived violation in the psychological contract during expatriation (Coyle-Shapiro \& Kessler, 2002).

The effects of psychological contract violation on expatriates' attitudes

From a social exchange perspective, the perceived violation in the psychological contract occurs when the norm of reciprocity is broken in the employment relationship (Gouldner, 1960). Therefore, the breaking of the norm of reciprocity can cause adverse consequences, such as negative employees' attitudes.

Among various employees' attitudes, job satisfaction, organizational commitment, and turnover intentions are of major interest to the expatriation management (Rynes, Colbert, \& Brown, 2002; Saari \& Judge, 2004).

Above all, one of the most widely studied attitudinal outcomes in the expatriate literature is job satisfaction (Hess \& Jepsen, 2009). Job satisfaction can be defined as a pleasurable condition that comes from the employee's positive evaluation of his or her job (Locke, 1976, 1984; Luthans, 1989; Nelson \& Quick, 
2006). Similarly, how the expatriate evaluates various facets of the international assignment determines his or her level of job satisfaction.

In this regard, the job satisfaction of expatriates is closely related to the perceived psychological contract violation, in that both are built around the compound evaluation of expatriates (Gakovic \& Tetrick, 2003; Suazo, 2009; Zhao, Wayne, Glibkowski, \& Bravo, 2007).

Indeed, prior research has revealed that employees appear to hold higher job satisfaction when their psychological contract is fulfilled (Atkinson, 2007; Gakovic \& Tetrick, 2003; Haggard, 2012; Kickul, Lester, \& Finkl, 2002; Suazo, 2009; Sutton \& Griffin, 2004; Tekleab, Takeuchi, \& Taylor, 2005; Tekleab \& Taylor, 2003; Zhao, Wayne, Glibkowski, \& Bravo, 2007).

Conversely, the perceptions of psychological contract violation would reduce job satisfaction of expatriates (Tekleab \& Taylor, 2003). According to equity theory, if expatriates perceive their exchanges with the MNE as inequitable, the psychological contract violation occurs (Taylor \& Tekleab, 2004). In the face of such a situation, expatriates are likely to adopt negative attitudes in order to restore equity. In other words, expatriates attempt to regain the perceived give-and-take balance by lowering their job satisfaction to a level commensurate with the efforts they put forth. Organizational commitment is another commonly used attitudinal outcome in expatriate research. Organizational commitment describes an employee's attachment to the organization that s/he works for (Allen \& Meyer, 1996; Becker, 2005; Buchanan, 1974; Kanter, 1968; Mathieu \& Zajac, 1990; Mowday, Porter, \& Steers, 1982). 
In this vein, there is a general belief that employees who are satisfied with their jobs are more prone to feel connected to their organizations. This means that employees with high job satisfaction have a strong desire to be part of their organizations. In fact, a positive relationship between job satisfaction and organizational commitment has been consistently found in studies (Mathieu \& Zajac, 1990; Meyer, Paunonen, Gellatly, Goffin, \& Jackson, 1989).

Moreover, according to previous findings, the effects of perceived psychological contract violation on organizational commitment is similar to those on job satisfaction, in that it decreases the employee's commitment to the organization (Coyle-Shapiro \& Kessler, 2000; Haggard, 2012; Kessler \& Undy, 1996; Lester, Turnley, Bloodgood, \& Bolino, 2002; Restubog, Bordia, \& Tang, 2006; Shore \& Barksdale, 1998).

As such, it can be expected that the perceived violation of the psychological contract has detrimental effects on organizational commitment of expatriates. Given the perceived psychological contract violation as an imbalance of social exchanges, expatriates decrease the psychological investment by reducing their commitment to the MNE, which promotes more balanced exchanges (Coyle-Shapiro \& Kessler, 2000).

Additionally, the negative effects of perceived psychological contract violation on both job satisfaction and organizational commitment become more apparent in the context of expatriation. This is because uncertainty is prevalent in the expatriation context; in turn, the role of the psychological contract is emphasized. 
In conclusion, the perceived psychological contract violation leads to low levels of expatriate's job satisfaction and organizational commitment. Based on the discussion above, the following hypothesis is suggested:

Hypothesis 1a: Perceived psychological contract violation negatively relates to (i) job satisfaction and (ii) organizational commitment.

The most frequently adopted measure of expatriate failure has been the premature return of the expatriate from the international assignment to his or her home country (Black \& Gregersen, 1990). Other terms are also used interchangeably, including expatriate turnover (Naumann, 1992).

Turnover occurs when the employment relationship ends. In the literature, voluntary and involuntary turnover are usually distinguished. More particularly, voluntary turnover is the employee-initiated termination of the employment relationship, such as resignation (Naumann, 1992; Reiche, 2009). On the one hand, involuntary turnover is the type of turnover that is initiated by the employer for various reasons, including marginal or poor performance, excessive absenteeism, or violation of a workplace policy (Naumann, 1992). It is usually in the form of dismissals or layoffs. Taken together, turnover, in its broadest sense, refers to the termination of the employment relationship, regardless of whether it is voluntary or involuntary (Mobley, Griffeth, Hand, \& Meglino, 1979; Shaw, Delery, Jenkins, \& Gupta, 1998). 
In this sense, turnover intentions reflect the desire or willingness of an employee to terminate his or her employment relationship (Elangovan, 2001; Tett \& Meyer, 1993). It would not only induce thoughts of quitting, but also sometimes precede actual turnover behavior in the near future (Byrne, 2005; Fishbein \& Ajzen, 1975; Hendrix, Robbins, Miller, \& Summers, 1998; Mobley, 1977; Steensma, Van Breukelen, \& Sturm, 2004). As a result, turnover intentions are deemed a significant predictor of actual turnover (Lambert, Hogan, \& Baron, 2001; Mobley, 1977; Steel \& Ovalle, 1984). In a similar vein, multiple studies have argued that turnover is not spontaneous, but rather a gradual psychological process of diminished engagement. In support of this argument, there is substantial evidence that turnover intentions are negatively related to organizational commitment (Allen \& Meyer, 1996; Tett \& Meyer, 1993). This association has also been found to be valid in the context of expatriation (Florkowski \& Fogel, 1999; Shaffer \& Harrison, 1998). Furthermore, employees are more likely to quit if they are not content with their jobs (Akerlof, Rose, Yellen, Ball, \& Hall, 1988; Avanzi, Fraccaroli, Sarchielli, Ullrich, \& van Dick, 2014; Freeman, 1980; Hulin, 1966; Lévy-Garboua, Montmarquette, \& Simonnet, 2007; March \& Simon, 1958; Podsakoff, LePine, \& LePine, 2007).

More importantly, a number of studies have shown that turnover is often caused by the perceived violation in the psychological contract (Ng \& Sorensen, 2008; Peiperl \& Baruch, 2003; Rhoades \& Eisenberger, 2002; Robinson \& Rousseau, 1994; Suazo, 2009; Turnley, Bolino, Lester, \& Bloodgood, 2003; Turnley \& Feldman, 1999; Zhao, Wayne, Glibkowski, \& Bravo, 2007). For example, De Hauw and De Vos (2010) found that employees are likely to maintain the employment 
relationship as long as the equitable balance in exchanges is guaranteed. In other words, the perceived psychological contract violation as the inequality of exchanges leads to an increase in turnover intentions.

Similarly, perceived violation of the psychological contract may also result in expatriates' intentions to quit. More specifically, when expatriates perceive an inequitable employment relationship, they are reluctant to remain with that relationship. It then leads to increased levels of turnover intention of expatriates. In fact, several studies have posited that the perceptions of inequity in the employment relationship result in withdrawal reactions on the basis of social exchange theory and equity theory (Geurts, Schaufeli, \& Rutte, 1999; Greenberg, 1990; Hom, Griffeth, \& Sellaro, 1984; Porter \& Steers, 1973). In conclusion, expatriates’ perceptions of psychological contract violation lead to a high propensity for the termination of expatriate employment relationship. Based on the discussion above, the following hypothesis is suggested:

Hypothesis 1b: Perceived psychological contract violation positively relates to turnover intentions.

\section{The moderating role of individual factors between perceived violation in the psychological contract and expatriates' attitudes}

The present dissertation discusses the individual factors that influence the relationship between perceived psychological contract violation and expatriates' 
attitudes from two aspects: cultural intelligence and previous international work experience.

\section{Cultural intelligence}

In light of the personal nature of the psychological contract, previous research has revealed that the psychological contract tends to be largely influenced by the individual situations of employees. Indeed, numerous recent studies have examined the possible moderation effects of individual variables on the relationship between perceived psychological contract violation and employees' attitudes, including personality (Tallman \& Bruning, 2008), individual characteristics (e.g., age, gender, emotional intelligence, and literacy level) (Ng \& Feldman, 2009; Schalk, 2004;

Tallman \& Bruning, 2008; Turnley, Bolino, Lester, \& Bloodgood, 2003), and jobrelated attributes (e.g., employment status, organizational trust, and career orientation) (Ainsworth \& Purss, 2009; Coyle-Shapiro \& Kessler, 2002; Hekman, Bigley, Steensma \& Hereford, 2009; Kickul \& Lester, 2001; Liao-Troth, 2001; Restubog, Bordia, \& Bordia, 2009; Skromme Granrose \& Baccili, 2006; Turnley, Bolino, Lester, \& Bloodgood, 2003).

Specifically, Schalk (2004) found that older employees are less likely than their younger counterparts to be affected by perceived psychological contract violation. $\mathrm{Ng}$ and Feldman (2009) found similar results where older employees exhibit higher levels of acceptance towards perceived violation in the psychological contract and thereby are less inclined to adapt their attitudes accordingly. 
The lifespan psychology elaborates that older employees tend to pay more attention to positive experiences and develop more realistic expectations about employment relationships than younger employees do (Carstensen, Isaacowitz, \& Charles, 1991).

Moreover, older and long-tenured employees generally have greater access to bargaining power and voice channels at work, and in turn, they are able to cope better with the psychological contract with their organization.

Additionally, another stream of research has investigated the influence of personality on perceived violation in the psychological contract (Jafri, 2014; Raja, Johns, \& Ntalianis, 2004; Zhao \& Chen, 2008). More particularly, Jafri (2014) found that both agreeable and conscious employees are less likely to perceive violation in their psychological contracts.

These findings can also be applied to the various types of employment relationships, such as the expatriate employment relationship. In fact, Lub and colleagues (2016) argued that different demographic characteristics cause expatriates to respond differently to the psychological contract.

With this in mind, this dissertation advances the argument that the usefulness of perceived psychological contract violation in predicting expatriates' attitudes is contingent upon the expatriate's level of cultural intelligence.

Working abroad mostly means working in another culture. In other words, expatriates encounter new and unfamiliar cultural values, norms, and practices during international assignments, albeit to different extents. 
In this regard, the cultural intelligence has been increasingly recognized as an important individual competency that facilitates cultural understanding. According to the definition provided by Early and Ang (2003), cultural intelligence is a set of cross-cultural capabilities to function effectively in multicultural settings.

More specifically, these cultural capabilities of individual are valid universally regardless of the circumstances in which they are applied. Also, cultural intelligence is not limited to a certain cultural ability, such as foreign language skills, but encompasses a wide array of abilities that would be critical to culturally diverse situations. To wit, cultural intelligence is neither country-specific nor specific to a particular cultural ability.

As hypothesized above, the failure of the MNE to fulfill its reciprocal obligations implied in the psychological contract may jeopardize the expatriates' attitudes, in line with the norm of reciprocity.

Yet, the negative effects of perceived psychological contract violation on expatriates' attitudes become weaker as expatriates possess higher levels of cultural intelligence. The reason is that culturally intelligent expatriates are likely to have a better understanding of cultures and thereby have a more realistic approach to exchanges occurring in different cultural settings. As such, the psychological contracts of culturally intelligent expatriates are less easily violated.

More particularly, those who are richly endowed with cultural intelligence would be well aware of the fact that the MNE may not be able to reciprocate adequately in a timely manner when operating in different countries. They also understand that the norm of reciprocity is easily breakable in the expatriate 
employment relationship primarily because of a high degree of uncertainty, which results mainly from different cultures (Stahl, 2001).

In fact, the expatriation is often characterized as uncertain, complex, and ambiguous. A series of these features makes it difficult for the MNE to specify and satisfy the psychological contracts of expatriates. This, in turn, increases the occurrence of perceived psychological contract violation in the expatriate employment relationship.

Under this circumstance, culturally intelligent expatriates tend to have a balanced and comprehensive view on the psychological contract; thus, they are less vulnerable to the perceived violation in the psychological contract.

In a similar vein, Kim, Kirkman, and Chen (2008) insisted that it is easier to understand unfamiliar cultures for the expatriate with higher cultural intelligence. One plausible explanation is that culturally intelligent expatriates are more likely to be able to gain pertinent information about the host country, recognize subtle cultural differences, and interact actively with people from other cultures (Brislin, Worthley, \& Macnab, 2006).

Taken together, the cultural intelligence may positively influence how expatriates construe their psychological contract in culturally diverse contexts of expatriation. For example, when the perceived psychological contract violation occurs, culturally intelligent expatriates understand that the violation is a part of expatriation; as a result, they are better equipped to bounce back to a previous status.

Although expatriates are expected to reciprocate perceptions of the psychological contract violation by lowering of job satisfaction, those with higher 
cultural intelligence are more likely to be resilient and hence their job satisfaction is presumably less changeable. To wit, the perceived psychological contract violation becomes less important in determining the job satisfaction of culturally intelligent expatriates.

In addition, when expatriates perceive that the psychological contract is violated, they are generally inclined to adapt their attitudes by reducing commitment to the MNE. However, it is not wholly applicable to culturally competent expatriates. That is, even though they may also feel detached and less committed to the MNE at some point, expatriates with higher cultural intelligence are less likely than those with lower cultural intelligence to be influenced by the perceived violation in the psychological contract.

Indeed, multiple studies have found that highly resilient employees display greater job satisfaction and organizational commitment than those of others in case of adversity (Luthans, Avolio, Avey, \& Norman, 2007; Luthans, Avolio, Walumbwa, \& Li, 2005; Shin, Taylor, \& Seo, 2012; Tugade, \& Fredrickson, 2004; Youssef \& Luthans, 2007).

The perceived psychological contract violation can result in further unintended consequences, such as high turnover intentions. However, culturally intelligent expatriates are assumed to contemplate whether to quit their assignments. Consistent with this assumption, prior research has reported the negative association between cultural intelligence and turnover intentions (Froese, Kim, \& Eng, 2016). As such, even when the MNE reneges on the psychological contract, those with higher levels of cultural intelligence are hesitant to terminate the expatriate employment 
relationship. In lieu of turnover intentions, they would seek to identify the underlying reasons for perceived psychological contract violation and adapt their psychological contract accordingly. Based on the discussion above, the following hypotheses are suggested:

Hypothesis 2a: Expatriate's cultural intelligence moderates the relationship between perceived psychological contract violation and (i) job satisfaction and (ii) organizational commitment, such that the negative relationship diminishes when the expatriate possesses higher levels of cultural intelligence than when s/he possesses lower levels of cultural intelligence.

Hypothesis 2b: Expatriate's cultural intelligence moderates the relationship between perceived psychological contract violation and turnover intentions, such that the positive relationship decreases when the expatriate possesses higher levels of cultural intelligence than when s/he possesses lower levels of cultural intelligence.

Previous international work experience

There is abundant evidence that previous international experience facilitates an expatriate's adjustment to a new culture (Black, 1988; Black \& Gregersen, 1991; Church, 1982; Cui \& Awa, 1992; Dunbar, 1992; Nicholson \& Imaizumi, 1993; Parker \& McEvoy, 1993; Selmer, 2002). 
According to a social learning perspective, it is likely that expatriates with greater previous international experience have been exposed to different cultures and thereby have had more opportunities to enhance cultural competence (Bochner, Hutnik, \& Furnham, 1986; Bochner, Mcleod, \& Lin, 1977; Brein \& David, 1971; Brislin, 1981; Toh \& DeNisi, 2007). As such, previous international experience has been believed to be a key predictor of expatriate success.

However, other studies have purported to demonstrate that previous international experience is not necessarily an effective predictor of expatriate success on international assignments (Bhaskar-Shrinivas, Harrison, Shaffer, \& Luk, 2005; Black, 1988; Black \& Gregersen, 1991; Black \& Stephens, 1989; Hechanova, Beehr, \& Christiansen, 2003). For example, in their meta-analysis, Bhaskar-Shrinivas and colleagues (2005) revealed that previous international experience is a weak predictor for successful expatriate adjustment.

In respect of these inconsistent findings, a number of recent studies have pointed out that it is a matter of how relevant the previous international experience is to the current expatriation (Kim \& Slocum, 2008; McNulty \& Selmer, 2017).

Accordingly, it is reasonable to assume that the work-related experience that expatriates gained while abroad is more likely to reinforce their capacity to carry out international assignments successfully.

For example, expatriates who completed previous international assignments are more prone to build accurate expectations about expatriation than those who travelled overseas or those who studied abroad. These accurate expectations about expatriation, in turn, promote better cross-cultural adaptation at least at work 
(Caligiuri \& Phillips 2003; Searle \& Ward 1990; Weissman \& Furnham, 1987). In a similar vein, Templer, Tay, and Chandrasekar (2006) found that realistic job previews positively influence work adjustment.

In this regard, accurate work expectations are related to positive perceptions of psychological contract. In fact, a number of studies have insisted that accurate work expectations are a central means of facilitating positive psychological contracts (Guzzo \& Noonan, 1994; Hiltrop, 1996; Morrison \& Robinson, 1997; Niehoff, Moorman, Blakely, \& Fuller, 2001; Paul, Niehoff, \& Turnley, 2000; Rousseau, 1995; Sims, 1994).

Taken together, the previous international work experience is expected to contribute to establishing a positive psychological contract. Indeed, several scholars have highlighted the fact that the psychological contract is largely based on the employee's past work experience (Morrison \& Robinson, 1997; Robinson \& Morrison, 2000; Rousseau, 1990; Schein, 1988).

Along with this, as hypothesized, when expatriates have more previous international work experience, they are likely to have more accurate and realistic expectations of their expatriation and thus be less bothered by the psychological contract violation. This is because they garner a greater understanding for the reality of expatriation through previous experiences, allowing them to develop an effective and attainable psychological contract and thereby to better deal with a perceived violation of the psychological contract. 
Similarly, Black, Mendenhall, and Oddou (1991) demonstrated that previous international experience increases the changes of establishing accurate expectations, and the accuracy of expatriates' expectations is essential to expatriate success.

In conclusion, previous international work experience inhibits the impact of perceived psychological contract violation on expatriates' attitudes, namely, job satisfaction, organizational commitment, and turnover intentions. Based on the discussion above, the following hypotheses are suggested:

Hypothesis 3a: Expatriate's previous international work experience moderates the relationship between perceived psychological contract violation and (i) job satisfaction and (ii) organizational commitment, such that the negative relationship diminishes when the expatriate possesses longer previous international work experience than when s/he possesses shorter previous international work experience.

Hypothesis 3b: Expatriate's previous international work experience moderates the relationship between perceived psychological contract violation and turnover intentions, such that the positive relationship decreases when the expatriate possesses longer previous international work experience than when s/he possesses shorter international work experience. 


\section{The moderating role of organizational factors between perceived violation in the psychological contract and expatriates' attitudes}

The present dissertation discusses the organizational factors that influence the relationship between perceived psychological contract violation and expatriates' attitudes from two aspects: the extent of cross-cultural training and the length of the international assignment.

\section{The extent of cross-cultural training}

In addition to the individual factors, the psychological contract is subject to organizational influences. In other words, the psychological contract varies dramatically, depending on the organizational circumstances (Coyle-Shapiro \& Parzefall, 2008; Richard, McMillan-Capehart, Bhuian, \& Taylor, 2009; Robinson, Kraatz, \& Rousseau, 1994; Silverthorne, 2004).

In fact, a plethora of studies have contended that organizational influences play a prominent role particularly in shaping the psychological contract, including organizational structures, management policies and procedures, and employment regulations (Conway \& Briner, 2005; Coyle-Shapiro \& Kessler, 2000; Coyle-Shapiro \& Parzefall, 2008; Guest, 1998; Guzzo \& Noonan, 1994; Herriot, Manning, \& Kidd, 1997; Rousseau, 1995; 2001; Rousseau \& Greller, 1994; Sparrow \& Cooper, 1998).

For example, Rousseau (1995) posited that the content of the psychological contract is heavily driven by organizational factors, such as human resource management practices. In particular, he elaborated that human resource management practices send a clear message as to what the organization expects from their 
employees and, in return, what employees can expect from the organization. As such, employees perceive such messages from human resource management practices as promises and understand the employment relationship accordingly (Rousseau, 1995; Sparrow, 1996). In a similar vein, Westwood, Sparrow, and Leung (2001) insisted that formal communication helps employees understand terms of their employment.

Further, some studies have argued that the training and development programs as one form of the human resource management practices help employees make their experiences in the new work environment more predictable and hence determine the state of their psychological contract (Shore \& Tetrick, 1994; Waiganjo, 2012).

Taken together, the training and development programs not only give employees an accurate picture of their role and job requirements, but also increase confidence regarding the future exchanges. Consequently, it contributes to the building of more realistic and deliverable psychological contract.

Considering that international assignments are carried out in overseas operations, dealing with different cultures is an integral part of expatriation. Indeed, a significant body of research has postulated that culture has a profound effect on the overall expatriation success (Black, Mendenhall, \& Oddou, 1991; Strubler, Park, \& Agarwal, 2011).

With the increased recognition of importance of culture in expatriation, much attention has been directed towards the cultural education in recent years. As a consequence, a number of MNEs endeavor to develop cross-cultural training programs for expatriates. Concretely, according to a Brookfield survey (Brookfield 
Global Relocation Services, 2015), the vast majority of MNEs (83\%) offered cultural training for at least some of their international assignments.

Although its primary focus is often on the development of foreign language competency and communication skills, cross-cultural training aims at providing a wider range of conceptual and practical tools that expatriates can apply when working abroad.

The reason for offering such cultural training programs lies in the fact that cross-cultural training cultivates expatriates' global mindset, enhances cultural competence, and eventually fosters expatriate success.

Unexpected, unusual, or unintended situations that disturb the employment relationship frequently occur during expatriation largely due to different cultures. This implies that even though the MNE wants to deliver the promises perceived, it is hard to do it due to external reasons during expatriation.

In this vein, cross-cultural training helps expatriates better cope with unexpected and negative events that cause perceived violation of the psychological contract in a new culture (Earley, 1987; Harris \& Moran, 1987). In particular, crosscultural training reduces conflicts in the expatriate employment relationship by educating expatriates about possible conditions that might actually limit future exchanges.

Accordingly, it can be argued that extensive cross-cultural training programs contribute to cultivating a positive psychological contract and thereby placate the expatriates' negative reactions to the perceived psychological contract violation. 
Specifically, expatriates become capable of benefiting from realistic previews of the expatriation through comprehensive cross-cultural training, which in turn increase the accuracy of expatriate perceptions regarding the employment relationship in different cultures. In other words, cultural understanding converts itself into the ability of expatriates to better adapt to the new employment relationship in expatriation context. Further, expatriates who are properly trained are better prepared for perceived violation in the psychological contract.

To wit, extensive and comprehensive cross-cultural training is expected to reduce the effects of perceived psychological contract violation on expatriates' attitudes (i.e., reduced job satisfaction, lowered organizational commitment, and increased turnover intentions) by forming accurate perceptions about the expatriation.

In support of the expectation, previous findings revealed that training has a positive influence on job satisfaction and organizational commitment of employees, while it is negatively associated with turnover intentions (Burke, 1995; Costen \& Salazar, 2011; José Chambel \& Sobral, 2011; Kesen, 2016; Lam, Lo, \& Chan, 2002; Mathieu, Tannenbaum, \& Salas, 1992; Roehl \& Swerdlow, 1999). Based on the discussion above, the following hypotheses are suggested:

Hypothesis 4a: The extent of cross-cultural training moderates the relationship between perceived psychological contract violation and (i) job satisfaction and (ii) organizational commitment, such that the negative relationship diminishes when cross-cultural training was provided to the 
expatriate to a larger extent than when it was provided to him or her to a lesser extent.

Hypothesis 4b: The extent of cross-cultural training moderates the relationship between perceived psychological contract violation and turnover intentions, such that the positive relationship decreases when cross-cultural training was provided to the expatriate to a larger extent than when it was provided to him or her to a lesser extent.

The length of the international assignment

Another organizational factor that has not received a great deal of attention in the literature on the expatriates' psychological contract is the length of the international assignment.

According to several studies, the psychological contract is largely dependent upon the length of the employment (Rousseau \& McLean, 1993; Smithson \& Lewis, 2000). That is, employees who are hired on a short-term basis have a different psychological contract with the organization from that of long-term employees (Rousseau, 1989, 1990, 1995; Rousseau \& Wade-Benzoni, 1995).

More specifically, temporary or short-term employees tend to develop a psychological contract that contains highly specific exchanges of narrow scope, primarily due to a relatively low level of reciprocal commitment arising from the employment relationship (Guest, 2004; McLean Parks, Kidder, \& Gallagher, 1998;

Rousseau, 1995; Rousseau \& Tijoriwala, 1998). In other words, short-term employees 
are likely to have few prospects of an employment relationship. Consistent with this, one of the participants in the study of Druker and Stanworth (2004, p. 70) stated:

"You don’t expect too much from employers if you are a temp."

Moreover, employees in short-term employment relationship are prone to hold a transactional psychological contract, which primarily involves the exchanges of monetary resources (De Cuyper \& De Witte, 2006, 2007; Guest, 2004; Guest, Isaksson, De Witte, 2010; Jong, Schalk, \& De Cuyper, 2009; Millward \& Brewerton, 1999). Taken together, short-term employees develop a transactional psychological contract that pertain to short-term and quid pro quo promises.

On the one hand, employees who hold a long-term employment relationship are likely to have a considerable relational element in their psychological contract, which centers on non-monetary and socio-emotional exchanges (Aselage \& Eisenberger, 2003; Coyle Shapiro \& Kessler, 2002; Rousseau, 1995; Rousseau \& McLean Parks, 1993).

In this regard, the relational psychological contract is more subjective than the transactional one when interpreting terms of the psychological contract. In other words, both the employee and employer may have a completely different understanding regarding contractual terms, particularly when the psychological contract is relational (De Cuyper \& De Witte, 2006; Rousseau, 1990, 1995). Consequently, the perceived psychological contract violation is more frequent and 
intense in the relational psychological contract that is typically associated with the long-term employment relationship (Reimann \& Guzy, 2017).

Similarly, there is considerable evidence that the state of short-term employees' psychological contracts is more positive than that of long-term employees (Guest \& Conway, 1998; Guest, Mackenzie Davey, \& Patch, 2003). This implies that the psychological contract of short-term employees is less susceptible to be violated (De Jong, Schalk, \& De Cuyper, 2009; Guest \& Clinton, 2005; Guest, Mackenzie Davey, \& Patch, 2003; Rousseau, 1995).

Besides, those who are employed on short-term contracts are expected to have a less adverse reaction to perceived violation in the psychological contract (Robinson \& Rousseau, 1994). This is because the negative impacts of perceived psychological contract violation can be offset by the short-term involvement. In fact, Robinson, Kraatz, and Rousseau (1994) found that when employees have a transactional psychological contract, their attitudinal reactions to perceived psychological contract violation are less severe.

In the same sense, the length of the international assignment would moderate the negative effects of perceived psychological contract violation on expatriates' attitudes. In particular, in the face of perceived violation in the psychological contract, expatriates working on the short-term international assignment would respond with a lower decrease of job satisfaction and organizational commitment and thereby have lower turnover intentions than long-term assignees. 
As previously stated, one reason is that short-term expatriates, in general, have limited involvement in the expatriate employment relationship, which leads to a high level of tolerance for the perceived psychological contract violation.

Another possible reason is that expatriates on the short-term international assignment may see their current assignment as a stepping-stone to better jobs; thus, they are reluctant to invest their personal resources in the form of time and effort to the expatriate employment relationship (Chmiel, Fraccaroli, \& Sverke, 2017). Considering such relatively low investment into the exchange, short-term assignees would be more cavalier about reneging on the perceived promises.

To the contrary, long-term expatriates are thought to invest more efforts in the employment relationship; thus, they would have more intense reactions to the perceived violation of the psychological contract (Guest, Isaksson, \& De Witte, 2010). Specifically, when their efforts are not reciprocated, long-term expatriates would reduce either job satisfaction or commitment to the MNE to a level that is perceived as commensurate with their efforts in order to restore the reciprocal relationship. In this way, the imbalanced social relationship derived from psychological contract violation is rectified. Based on the discussion above, the following hypotheses are suggested:

Hypothesis 5a: The length of the international assignment moderates the relationship between perceived psychological contract violation and (i) job satisfaction and (ii) organizational commitment, such that the negative 
relationship diminishes when the length of the international assignment is shorter than when it is longer.

Hypothesis 5b: The length of the international assignment moderates the relationship between perceived psychological contract violation and turnover intentions, such that the positive relationship decreases when the length of the international assignment is shorter than when it is longer.

\section{The moderating role of national factor between perceived violation in the psychological contract and expatriates' attitudes}

The present dissertation discusses the national factor that influences the relationship between perceived psychological contract violation and expatriates' attitudes from an aspect of cultural distance.

\section{Cultural distance between home and host countries}

The psychological contract is inherently dynamic and context-bound; thus, it constantly changes depending on the circumstances. In particular, prior research has emphasized the significant influence of social context on the psychological contract, such as the country's political, economic, and social situation, the demographic composition, the stages of industrial development, societal norms, and employment and labor law (Bendix, 2010; Linde, 2015).

Notwithstanding the dynamic nature of the psychological contract, previous studies on psychological contracts of expatriates have adopted the construct of those 
which are largely applicable to the domestic employment relationship. This, in turn, results in the neglect of a culture that exerts a considerable influence in the expatriation context.

In essence, expatriation involves business operations across national boundaries. In this sense, cultural distance has long been recognized as an indispensable part of the expatriation.

Cultural distance is commonly defined as the extent of cultural differences between two countries (Kogut \& Singh, 1988; Shenkar, 2001; Sousa \& Bradley, 2006). This implies that the greater differences in cultural values and norms create a greater cultural distance between the two countries.

In this vein, unexpected occurrences arising from cultural differences are fairly common when operating in a culturally distant country (Dowling \& Welch 2004; Maude, 2011). More specifically, a variety of unforeseen circumstances that may interfere with delivering on the perceived promises often occur during expatriation, particularly when there is a greater cultural distance. That is, when operating in culturally distant countries, there are additional difficulties for MNEs to identify and fulfill the psychological contracts of expatriates.

In summary, a greater cultural distance results in a high degree of perceived uncertainty of expatriates (Shenkar, 2001). In line with this, Evans and Mavondo (2002) found empirical evidence that expatriates who perceive greater cultural differences in the host country are more likely to experience higher levels of uncertainty during their expatriation period. 
Therefore, considering that the psychological contract serves a key role in reducing uncertainty and increasing predictability about future exchanges in the employment relationship, expatriates are expected to depend more on the psychological contract in culturally distant destinations.

In support of this expectation, a great deal of research has shown that greater uncertainty leads to a greater reliance on the existing employment relationship (Cook \& Emerson, 1978, 1984; Kollock, 1994; Lawler \& Yoon, 1996; Sorenson \& Waguespack, 2006). In other words, under conditions of great uncertainty, employees appear to continue the exchange relationship with the same organization in order to alleviate the perils of uncertainty. This is because in many instances the existing employment relationship seems to better ensure the reciprocal norm of social exchange than possible alternatives elsewhere.

Similarly, given the uncertainty associated with expatriation, expatriates strive to maintain current expatriate employment relationship and place high value on their existing psychological contract.

Therefore, the prevalent uncertainty inherent to expatriation makes the psychological contract more influential (McNulty, 2013; Shore \& Tetrick, 1994). In this sense, the increasing significance of the psychological contract would elicit more severe reactions to the perceived violation in the psychological contract.

Moreover, expatriates tend to rely extensively on perceived organizational support, because the line between their professional and personal lives is often blurred during expatriation. In turn, MNEs are extensively involved and exercise profound influence over expatriates' lives both on and off the job. 
Specifically, many aspects of personal lives, which are not usually present in domestic settings, such as housing, spouse vocational assistance, and child education assistance, can be part of the psychological contracts of expatriates, especially when considerable cultural differences exist between home and host countries (Gail Lewis, 1997; Guzzo, Nelson, \& Noonan, 1992; Guzzo, Noonan, \& Elron, 1994; Perkins \& Daste, 2007; Suutari, Tornikoski, \& Mäkelä, 2012; Tornikoski, 2011).

This broader range of promises increases the likelihood of expatriates perceiving violation in their psychological contract during expatriation. It also increases the intensity of response to the perceived psychological contract violation (Guzzo, Noonan, \& Elron, 1994; Rousseau, 1995).

Indeed, perceived violation of the psychological contract usually occurs during unpredictable situations. Besides, previous studies have found that uncertainty originating from organizational changes heightens employees' reactions to the perceived psychological contract violation (Lo \& Aryee, 2003; Van Der Vaart, Linde, \& Cockeran, 2013; Zhao, Wayne, Glibkowski, \& Bravo, 2007).

Taken together, it is anticipated that expatriates who are sent to the culturally distant country react more intensely to the perceived psychological contract violation, whereas expatriates who are assigned to the culturally close country are less vulnerable to the effects of perceived psychological contract violation.

In other words, a smaller cultural distance between home and host countries mitigates the damaging effects of perceived psychological contract violation on expatriates' attitudes (i.e., decreased job satisfaction, reduced organizational commitment, and increased turnover intentions). In support of this, previous studies 
have postulated the association between unfamiliar cultures of the host country and negative expatriates' attitudes (Selmer, 2004; Torbiörn, 1988). Based on the discussion above, the following hypotheses are suggested:

Hypothesis 6a: Cultural distance between home and host countries moderates the relationship between perceived psychological contract violation and (i) job satisfaction and (ii) organizational commitment, such that the negative relationship diminishes when the cultural distance between home and host countries is smaller than when it is larger.

Hypothesis 6b: Cultural distance between home and host countries moderates the relationship between perceived psychological contract violation and turnover intentions, such that the positive relationship decreases when the cultural distance between home and host countries is smaller than when it is larger. 
Figure 1 shows the proposed conceptual model.

Figure 1.

Conceptual model of research

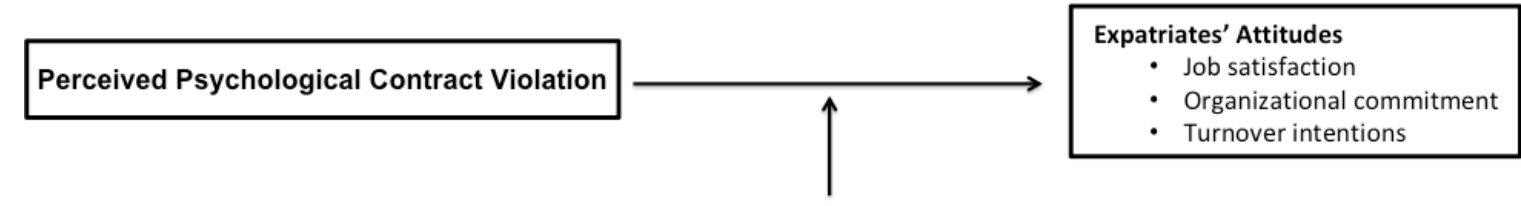

Individual Factors

- Cultural intelligence

- Previous international work experience

Organizational Factors

- The extent of cross-cultural training

- The length of the international assignment

National Factors

- Cultural distance between home and host countries

\section{CHAPTER III: RESEARCH DESIGN AND METHODOLOGY}

This chapter provides sufficient detail about the methodology used to test the hypotheses presented in Chapter II.

\section{Sample and data collection}

The sample used in this dissertation was a convenience sample, where participants were recruited through personal contacts of a researcher. Although it is considered to be less rigorous and representative, personal contacts generally elicit higher response rates (Allred \& Davis, 2011).

The sample was drawn from expatriates who are currently working in foreign subsidiaries of Korean conglomerate companies that are located in the United States, 
China, Japan, and Taiwan. Conglomerate companies operate across a number of different businesses and industries on a global scale (Janelli \& Yim, 1993).

Participants completed the questionnaire on two separate occasions that were two weeks apart. Even though previous studies have mainly adopted the crosssectional analysis (Bal, De Lange, Jansen, \& Van Der Velde, 2008; Ng \& Feldman, 2009), a cross-sectional study is often limited in its ability to draw causal inferences. Therefore, in order to establish a causal link, this dissertation used the research design in which perceived psychological contract violations and potential moderators were measured at one point in time and expatriate attitudes, as dependent variables, were measured two weeks later. An interval of two weeks was considered long enough for participants to have forgotten their previous responses, yet short enough to assume that the perceived violation in the psychological contract has not changed. The questionnaires can be found in Appendices 1 and 2.

To assure validity of questionnaires, the translation-back-translation procedures were used as recommended by Brislin (1976). Specifically, the questionnaires in the original English were first translated into Korean and then translated back into English.

The questionnaires were distributed both online and on paper. Also, selfadministered questionnaires were used. This is because the questionnaire contained some sensitive questions (Rossi, Wright, \& Anderson, 1983), such as personal feelings about his or her supervisor and whether s/he perceived there were psychological contract violations. 
The first questionnaire was sent to 250 expatriates. Of the 250 questionnaires sent out, 181 were responded to at Time 1 . The response rate at Time 1 was 72.4 percent. The second questionnaire, at Time 2, was distributed two weeks later to the 181 participants of the first questionnaire. Of the 181 participants, 168 completed surveys at Time 2, yielding a 92.81 percent response rate. This dissertation used multiple reminders to increase response rates (Heberlein \& Baumgartner, 1978).

Only those participants who completed two questionnaires $(\mathrm{N}=168)$ were included in the final analysis. The demographic characteristics of the participants are summarized in Table 1. As shown in Table 1, most of the participants (45\%) fell between 31 and 40 years of age, with 27 percent aged between 20 and 30 and the rest (27\%) aged between 41 and 50. Male participants were overrepresented in the sample (65\% versus $35 \%$ female). The vast majority of participants (86\%) had a Bachelor's degree, with 14 percent $(\mathrm{N}=24)$ holding a Master's degree. Around 37 percent of the participants have worked for their current MNE for less than one year. Nearly one third $(30.95 \%)$ of all participants indicated reasonably fluent host country language ability. In general, expatriates are highly educated and fluent in foreign languages (Carraher, Sullivan, \& Carraher, 2005; Cook, 2013). 
Table 1.

Demographic information $(N=168)$

\begin{tabular}{|l|l|l|}
\hline Variable & Number & Percent \\
\hline Age & & \\
\hline $20-30$ & 46 & 27.38 \\
\hline $31-40$ & 76 & 45.24 \\
\hline $41-50$ & 46 & 27.38 \\
\hline Gender & & \\
\hline Male & 110 & 65.48 \\
\hline Female & 58 & 34.52 \\
\hline Education & & \\
\hline Barchelors & 144 & 85.71 \\
\hline Masters & 24 & 14.29 \\
\hline Organizational tenure & & \\
\hline Less than 1 year & 62 & 36.90 \\
\hline $1-3$ years & 57 & 33.93 \\
\hline 4-7 years & 41 & 24.40 \\
\hline $8-15$ years & 8 & 4.76 \\
\hline Host country language & & \\
\hline Not at all & 14 & 8.33 \\
\hline Some understanding & 43 & 25.60 \\
\hline Fair & 50 & 29.76 \\
\hline Reasonably fluent & 52 & 30.95 \\
\hline Fluent & 9 & 5.36 \\
\hline
\end{tabular}

\section{Measurements}

Perceived psychological contract violation

Perceived psychological contract violation was assessed with a multi-item measure developed by Turnley and Feldman (1999).

First, participants were asked to indicate how important 16 specific aspects of the psychological contract are to them personally. These 16 aspects were drawn from prior research (Robinson \& Morrison, 1995; Rousseau, 1990), including salary, pay raises, bonuses, training, advancement opportunities, career development, overall 
benefits, retirement benefits, health care benefits, decision-making input, job responsibility, job challenge, feedback on job performance, supervisory support, organizational support, and job security. Responses were provided using a 10-point scale, ranging from 1 (Not important) to 10 (Extremely important).

Then, participants were asked to indicate how fairly well their organization had satisfied their perceived expectations. Responses were made on a five-point scale with the following options: -2 (received much less than promised); -1 (received less than promised); 0 (received as promised); 1 (received more than promised); and 2 (received much more than promised). Likewise, it is important to capture the full range of variation possible in the psychological contract - from under-fulfillment to over-fulfillment (Robinson, 1996; Turnley \& Feldman, 2000).

The perceived violation in the psychological contract was then calculated by multiplying the magnitude of perceived violation on each aspect by the importance of the same aspect and summing across all 16 aspects of the psychological contract.

Lastly, the degree of perceived psychological contract violation was reverse scored. Thus, a high score on this measure indicates a greater extent of perceived psychological contract violation.

To assess the validity of this measure, participants were also asked to indicate the overall level of perceived fulfillment in the psychological contract using a singleitem measure (Robinson, Kraatz, \& Rousseau, 1994; Robinson \& Rousseau, 1994). Responses were taken on a five-point Likert scale ranging from 1 (very poorly fulfilled) to 5 (very well fulfilled). As can be seen in Table 2, there was a significant positive correlation between two measures $(\mathrm{r}=0.81, \mathrm{p}<0.001)$. 
Table 2.

Correlation between the reverse score of perceived psychological contract violation and perceived psychological contract fulfillment

\begin{tabular}{lcc}
\hline & $\mathbf{1}$ & $\mathbf{2}$ \\
\hline $\begin{array}{l}\text { 1. Reverse score of } \mathrm{PCV}^{\mathrm{a}} \\
\text { 2. } \mathrm{PCF}^{\mathrm{b}}\end{array}$ & - & $0.81^{* * *}$ \\
\hline
\end{tabular}

Notes: $\dagger \mathrm{p}<0.1, * \mathrm{p}<.05, * * \mathrm{p}<.01, * * * \mathrm{p}<.001$

$\mathrm{H}_{\mathrm{a}}$ is positive correlation.

a: PCB=Perceived Psychological Contract Violation,

b: PCF: Perceived Psychological Contract Fulfillment

\section{Cultural intelligence}

Cultural intelligence was measured by the short form of cultural intelligence scale (SFCQS) developed by Thomas et al. (2015).

The SFCQS consists of 10 items, covering the three dimensions of cultural intelligence: cultural knowledge ( 2 items), cultural skills (5 items), and cultural metacognition (3 items).

Participants were asked to indicate the extent of their agreement or disagreement with statements using a five-point Likert scale ranging from 1 (not at all) to 5 (extremely well).

Previous international work experience

Previous international work experience was measured by a single item, asking "What is the total number of years of experience you had working in a foreign country prior to the current assignment?" Responses were provided on a five-point 
scale with the following choices: 1 (no experience); 2 (less than 1 year); 3 (1-2 years); 4 ( $3-5$ years); and 5 (more than 5 years).

\section{The extent of cross-cultural training}

The extent of cross-cultural training was measured by a single item, asking "Please indicate the extent to which cultural training is provided." Responses were provided on a five-point Likert scale ranging from 1 (to a very little extent) to 5 (to a very great extent).

As noted above, not all MNEs provide cross-cultural training to expatriates. Of the 168 participants, only 85 expatriates receive some kind of cross-cultural training. Only those who received cross-cultural training were used for the analysis.

\section{The length of the international assignment}

The length of the international assignment was measured by a single item, asking "Please specify duration of your current international assignment in years." Responses were provided on a four-point scale with the following options: 1 (less than 1 year); 2 ( $1-2$ years); 3 ( $3-5$ years); and 4 (more than 5 years).

\section{Cultural distance between home and host countries}

Despite growing criticism (Shenkar, 2001), cultural distance is typically measured with Kogut and Singh's (1988) index, which is derived from Hofstede's (1984) work on national culture. This index requires several home and host country 
pairs. However, the sample of this dissertation showed only limited variation in this respect.

In lieu of Kogut and Singh's measure of cultural distance, therefore, this dissertation adopted the individual's perception of the cultural differences between home and host countries to measure cultural distance. In fact, recent research has branched out, beyond the Kogut and Singh's measure, to a more individual based view of cultural distance (Dow \& Karunaratna, 2006; Parente, Baack, \& Almeida, 2007). One possible explanation for this phenomenon is that perceived cultural distance is inherently more idiosyncratic and influenced by the surrounding contexts (Kirkman, Lowe, \& Gibson, 2006; Leung, Bhagat, Buchan, Erez, \& Gibson, 2005). Accordingly, cultural distance was measured by a single item, asking "Please indicate how similar or different the culture of the current host country is from your home country culture.” Responses were provided on a five-point Likert scale ranging from 1 (very different) to 5 (very similar). This item was reverse scored. Thus, a high score indicates a greater cultural distance.

\section{Job satisfaction}

Job satisfaction was measured by six items taken from Brayfield and Rothe's job satisfaction index (1951) (Agho, Mueller, \& Price, 1993; Aryee, Luk, Leung, \& Lo, 1999). Participants were asked to indicate the extent of their agreement or disagreement with statements using a five-point Likert scale ranging from 1 (strongly disagree) to 5 (strongly agree). 
According to the objective of this dissertation, the word 'job' was replaced with 'international assignment'. Besides, one reverse-coded item was reframed to the positive. For example, 'I am often bored with my job' was reworded to be 'I am seldom bored with my international assignment'.

\section{Organizational commitment}

Organizational commitment was accessed with an eight-item affective commitment scale (ACS) extracted from Allen and Meyer's Organizational Commitment Scale (1996).

Participants were asked to indicate the extent of their agreement or disagreement with statements using a five-point Likert scale ranging from 1 (strongly disagree) to 5 (strongly agree).

Four reverse-coded items were reframed to the positive. For example, 'I think that I could easily become as attached to another organization as I am to this one' was reworded to be 'I do not think that I could easily become as attached to another organization as I am to this one'.

\section{Turnover intentions}

Turnover intentions were measured by four items taken from Caligiuri's (1997) measure. Participants were asked to indicate the extent of their agreement or disagreement with statements using a five-point Likert scale ranging from 1 (definitely no) to 5 (definitely yes). 
One reverse-coded item was reframed to the positive. For example, 'Would you have accepted this expatriate assignment if you knew what you were getting yourself into?' was reworded to be 'Would you have rejected this expatriate assignment if you knew what you were getting yourself into?'

\section{Controls}

Based on previous studies investigating similar relationships, several variables were controlled for in the analysis to rule out alternative explanations (Kickul \& Lester, 2001; Robinson, 1996; Rousseau, 1995; Turnley, Bolino, Lester, \& Bloodgood, 2003).

Specifically, for all analyses, age, gender, the level of education, and the organizational tenure (measured as the expatriate's tenure with the MNE in years) were controlled for.

Further, the expatriate's host country language ability was controlled for, because it is commonly considered relevant to the positive attitudes of expatriates (Abe \& Wiseman, 1983; Church, 1982; Cui \& Van Den Berg, 1991; Kim \& Slocum, 2008).

I also controlled for the personality traits measured by a 10 -item short version of the big five inventory, because the subjective nature of the psychological contract implies that the personality may have an effect on the expatriate's perception of psychological contract violation (Nikolaou \& Tomprou, 2007). 


\section{CHAPTER IV: ANALYSIS AND RESULTS}

This chapter elucidates the process of data analysis and unveils the primary research findings of the research as derived from the questionnaires.

\section{Initial analysis}

The analysis began with calculation of the means, standard deviations, reliabilities, and correlations among all variables, reported in Table 3. In particular, internal consistency reliabilities for multi-item scales (i.e., job satisfaction, organizational commitment, turnover intentions, and cultural intelligence) were estimated using Cronbach's alpha. All values were above 0.7 , indicating high internal consistency.

The results show that there was a significant negative correlation between perceived violation of the psychological contract and job satisfaction $(r=-0.8, p$ $<.001)$ and organizational commitment $(\mathrm{r}=-0.64, \mathrm{p}<.001)$, indicating that as a perceived violation of the psychological contract increases, both job satisfaction and organizational commitment of expatriates decrease.

Turnover intentions, on the one hand, were positively correlated with perceived psychological contract violation, which means the more psychological contract violation expatriates perceive, the more they are willing to terminate the employment relationship. 
Table 3.

Means, standard deviations, reliabilities and correlations among all variables $(N=168)$

\begin{tabular}{|c|c|c|c|c|c|c|c|c|c|c|c|}
\hline & $\mathbf{M}$ & SD & $\mathbf{1}$ & 2 & 3 & 4 & 5 & 6 & 7 & 8 & 9 \\
\hline 1. $\mathrm{PCV}^{\mathrm{a}}$ & -6.34 & 35 & - & $-0.80 * * *$ & $-0.64 * * *$ & $0.67 * * *$ & $-0.17 *$ & -0.10 & -0.11 & 0.02 & 0.10 \\
\hline 2. Job satisfaction & 3.56 & 0.41 & & $(0.85)$ & $0.61 * * *$ & $-0.60 * * *$ & 0.12 & 0.12 & 0.13 & -0.05 & -0.12 \\
\hline 3. Organizational commitment & 3.86 & 0.24 & & & $(0.79)$ & $-0.70 * * *$ & -0.03 & 0.11 & 0.12 & -0.08 & -0.06 \\
\hline 4. Turnover intentions & 3.01 & 0.45 & & & & $(0.76)$ & -0.004 & -0.09 & -0.03 & 0.04 & 0.12 \\
\hline 5. Cultural intelligence & 3.03 & 0.74 & & & & & $(0.95)$ & $0.61 * * *$ & $0.52 * * *$ & $-0.63 * * *$ & $-0.64 * * *$ \\
\hline 6. Previous IW experience ${ }^{b}$ & 2.99 & 1.03 & & & & & & - & $0.94 * * *$ & $-0.88 * * *$ & $-0.65 * * *$ \\
\hline 7. Extent of Cross-cultural training ${ }^{c}$ & 3 & 1 & & & & & & & - & $-0.88 * * *$ & $-0.50 * * *$ \\
\hline 8. Length of the $\mathrm{IA}^{\mathrm{d}}$ & 2.54 & 1.04 & & & & & & & & - & $0.68 * * *$ \\
\hline 9. Cultural distance & 2.71 & 0.97 & & & & & & & & & - \\
\hline 10. $\mathrm{Age}^{\mathrm{e}}$ & 3 & 0.74 & & & & & & & & & \\
\hline 11. Gender ${ }^{\mathrm{f}}$ & 1.35 & 0.48 & & & & & & & & & \\
\hline 12. Education & 2.14 & 0.35 & & & & & & & & & \\
\hline 13. Organizational tenure & 1.97 & 0.90 & & & & & & & & & \\
\hline 14. Host country language & 2.99 & 1.06 & & & & & & & & & \\
\hline 15. Big5_Agreeableness & 6.13 & 0.99 & & & & & & & & & \\
\hline 16. Big5_Openness & 6.13 & 0.93 & & & & & & & & & \\
\hline 17. Big5_Extraversion & 6.48 & 0.87 & & & & & & & & & \\
\hline 18. Big5_Conscientiousness & 6.21 & 0.90 & & & & & & & & & \\
\hline 19. Big5_Emotional stability & 5.79 & 0.85 & & & & & & & & & \\
\hline
\end{tabular}

Notes: $† \mathrm{p}<0.1, * \mathrm{p}<.05, * * \mathrm{p}<.01, * * * \mathrm{p}<.001$

Reliabilities are listed in parentheses on the diagonal.

${ }^{\mathrm{a}} \mathrm{PCV}=$ Perceived Psychological Contract Violation, ${ }^{\mathrm{b}}$ Previous IW experience=Previous International Work Experience,

${ }^{\mathrm{c}}$ Extent of Cross-cultural training: $\mathrm{N}=85,{ }^{\mathrm{d}}$ Length of the IA=The Length of the International Assignment, ${ }^{\mathrm{e}}:$ Range $1-5,5$ highest, ${ }^{\mathrm{f}}: 1=$ male, $2=$ female 
Table 3. (continued)

\begin{tabular}{|c|c|c|c|c|c|c|c|c|c|}
\hline 10 & 11 & 12 & 13 & 14 & 15 & 16 & 17 & 18 & 19 \\
\hline 0.10 & -0.10 & -0.001 & 0.04 & -0.10 & -0.06 & -0.01 & 0.01 & -0.02 & 0.03 \\
\hline$-0.15 \dagger$ & 0.07 & -0.01 & -0.004 & $0.17 *$ & 0.07 & 0.10 & -0.02 & 0.03 & 0.03 \\
\hline-0.12 & 0.02 & -0.06 & $-0.13 \dagger$ & $0.18 *$ & $0.18 *$ & $0.16^{*}$ & 0.04 & 0.09 & 0.12 \\
\hline 0.04 & -0.003 & -0.004 & 0.01 & -0.01 & 0.01 & 0.08 & 0.08 & 0.01 & 0.02 \\
\hline-0.09 & 0.08 & -0.07 & 0.04 & -0.07 & -0.13 & -0.11 & -0.12 & $-0.20 * *$ & $-0.19 *$ \\
\hline-0.07 & 0.03 & -0.03 & -0.01 & -0.04 & -0.10 & -0.07 & -0.07 & -0.13 & -0.10 \\
\hline-0.16 & -0.13 & 0.07 & -0.04 & $-0.24^{*}$ & -0.16 & -0.17 & -0.13 & -0.17 & $-0.20 \dagger$ \\
\hline $0.13 \dagger$ & 0.01 & 0.05 & -0.02 & 0.06 & 0.06 & 0.05 & 0.04 & $0.14 \dagger$ & 0.08 \\
\hline $0.18 *$ & 0.01 & -0.003 & -0.01 & -0.01 & 0.03 & 0.03 & 0.01 & 0.08 & 0.04 \\
\hline \multirow[t]{10}{*}{-} & 0 & -0.02 & $0.14 \dagger$ & 0.01 & -0.02 & -0.03 & -0.03 & -0.02 & -0.05 \\
\hline & - & -0.05 & 0.09 & 0.05 & $-0.21 * *$ & -0.07 & -0.11 & $-0.15 \dagger$ & -0.03 \\
\hline & & - & $0.32 * * *$ & 0.08 & 0.07 & 0.06 & -0.01 & 0.09 & 0.10 \\
\hline & & & - & 0.02 & $-0.15 \dagger$ & -0.10 & -0.01 & -0.07 & -0.12 \\
\hline & & & & - & $0.61 * * *$ & $0.60 * * *$ & $0.50 * * *$ & $0.56 * * *$ & $0.61 * * *$ \\
\hline & & & & & $(0.71)$ & $0.62 * * *$ & $0.55^{* * *}$ & $0.64 * * *$ & $0.64 * * *$ \\
\hline & & & & & & $(0.73)$ & $0.47 * * *$ & $0.65 * * *$ & $0.59 * * *$ \\
\hline & & & & & & & $(0.50)$ & $0.51 * * *$ & $0.41 * * *$ \\
\hline & & & & & & & & $(0.55)$ & $0.54 * * *$ \\
\hline & & & & & & & & & $(0.61)$ \\
\hline
\end{tabular}




\section{Hypothesis testing}

To examine hypotheses, the stepwise multiple regression analysis was performed. Specifically, in all equations, control variables (i.e. age, gender, education, organizational tenure, host country language ability, and personality traits) were entered in the first step (Model 1). Although there existed a few of the marginal effects for a few controls - particularly, host country language and openness to experience - on job satisfaction, no significant effects of these control variables were found on two other dependent variables, indicating the non-existence of any external effects that could result from these variables.

Subsequently, the main independent variable (i.e., perceived psychological contract violation) was added to the regression in the second step (Model 2). The regression results for each dependent variable, namely job satisfaction, organizational commitment, and turnover intentions, are presented in Table 4.1, 4.2, and 4.3, respectively. 
Table 4.1.

Hierarchical regressions predicting the impact of perceived psychological contract violation on job satisfaction

\begin{tabular}{|c|c|c|c|c|c|c|c|c|}
\hline \multirow[t]{2}{*}{ Dependent Variables } & \multicolumn{8}{|c|}{ Job Satisfaction } \\
\hline & Model 1 & Model 2 & Model 3 & Model 4 & Model 5 & Model 6 & Model 7 & Model 8 \\
\hline \multicolumn{9}{|l|}{ Controls } \\
\hline Age & $-0.16^{*}$ & -0.08 & -0.05 & -0.07 & -0.01 & -0.06 & -0.07 & -0.04 \\
\hline Gender & 0.04 & -0.05 & -0.04 & -0.04 & 0.00 & -0.04 & -0.03 & -0.02 \\
\hline Education & -0.03 & -0.04 & -0.04 & -0.03 & 0.01 & -0.02 & -0.02 & -0.01 \\
\hline Organizational tenure & 0.01 & 0.05 & 0.06 & 0.05 & 0.05 & 0.04 & 0.05 & 0.07 \\
\hline Host country language & $0.27 *$ & $0.13 \dagger$ & $0.13^{*}$ & $0.13 \dagger$ & 0.15 & $0.13 \dagger$ & $0.13 \dagger$ & 0.15 \\
\hline Big5_Agreeability & 0.06 & -0.06 & -0.07 & -0.06 & -0.05 & -0.07 & -0.07 & -0.10 \\
\hline Big5_Openness to experience & 0.09 & $0.12 \dagger$ & $0.11 \dagger$ & $0.11 \dagger$ & 0.14 & $0.11 \dagger$ & $0.13 \dagger$ & $0.18 \dagger$ \\
\hline Big5_Extroversion & -0.14 & -0.07 & -0.07 & -0.07 & 0.06 & -0.07 & -0.07 & 0.05 \\
\hline Big5_Conscientiousness & -0.07 & -0.08 & -0.07 & -0.08 & -0.16 & -0.07 & -0.09 & -0.18 \\
\hline Big5_Emotional stability & -0.13 & 0.03 & 0.02 & 0.04 & -0.05 & 0.05 & 0.05 & -0.02 \\
\hline \multicolumn{9}{|l|}{ Predictor } \\
\hline $\mathrm{PCV}^{\mathrm{a}}$ & & $-0.79 * * *$ & $-0.83 * * *$ & $-0.80 * * *$ & $-0.69 * * *$ & $-0.81 * * *$ & $-0.80 * * *$ & $-0.73 * * *$ \\
\hline \multicolumn{9}{|l|}{ Moderators } \\
\hline Cultural intelligence & & & -0.02 & & & & & -0.08 \\
\hline $\mathrm{PCV} \times \mathrm{CQ}^{\mathrm{b}}$ & & & $0.16^{* * *}$ & & & & & 0.12 \\
\hline Previous IW Experience ${ }^{c}$ & & & & 0.03 & & & & 0.22 \\
\hline PCV $\times$ Previous IW Experience & & & & $0.08 \dagger$ & & & & -0.08 \\
\hline Extent of $\mathrm{CCT}^{\mathrm{d}}$ & & & & & 0.05 & & & 0.04 \\
\hline $\mathrm{PCV} \times$ Extent of CCT & & & & & 0.09 & & & -0.16 \\
\hline Length of the $\mathrm{IA}^{\mathrm{e}}$ & & & & & & -0.01 & & 0.27 \\
\hline PCV $\times$ Length of the IA & & & & & & $-0.13 * *$ & & -0.19 \\
\hline
\end{tabular}




\begin{tabular}{lllllllll} 
Cultural Distance & & & & & & -0.01 & -0.05 \\
$\mathrm{PCV} \times$ Cultural Distance & & & & & & $-0.14 * *$ & -0.13 \\
$\mathrm{R}^{2}$ & 0.08 & $0.67 * * *$ & $0.70^{* * *}$ & $0.68 * * *$ & $0.62 * * *$ & $0.69 * * *$ & $0.69 * * *$ & $0.67 * * *$ \\
$\mathrm{~N}$ & 168 & 168 & 168 & 168 & 85 & 168 & 168 & 85 \\
\hline
\end{tabular}

Notes: $\uparrow \mathrm{p}<0.1, * \mathrm{p}<.05, * * \mathrm{p}<.01, * * * \mathrm{p}<.001$

${ }^{\mathrm{a}} \mathrm{PCV}=$ Perceived Psychological Contract Violation, ${ }^{\mathrm{b}} \mathrm{CQ}=\mathrm{Cultural}$ Intelligence, ${ }^{\mathrm{c}}$ Previous IW Experience=Previous International Work Experience, ${ }^{\mathrm{d}}$ Extent of CCT=Extent of Cross-Cultural Training, ${ }^{\mathrm{e}}$ Length of the IA=Length of the International Assignment 
Table 4.2.

Hierarchical regressions predicting the impact of perceived psychological contract violation on organizational commitment

\begin{tabular}{|c|c|c|c|c|c|c|c|c|}
\hline \multirow[t]{2}{*}{ Dependent Variables } & \multicolumn{8}{|c|}{ Organizational Commitment } \\
\hline & Model 1 & Model 2 & Model 3 & Model 4 & Model 5 & Model 6 & Model 7 & Model 8 \\
\hline \multicolumn{9}{|l|}{ Controls } \\
\hline Age & -0.12 & -0.05 & -0.01 & -0.04 & -0.04 & -0.03 & -0.05 & -0.05 \\
\hline Gender & 0.03 & -0.04 & -0.03 & -0.04 & -0.10 & -0.04 & -0.03 & -0.07 \\
\hline Education & -0.05 & -0.06 & -0.06 & -0.05 & -0.08 & -0.04 & -0.04 & -0.09 \\
\hline Organizational tenure & -0.08 & -0.06 & -0.03 & -0.05 & -0.01 & -0.07 & -0.05 & -0.04 \\
\hline Host country language & 0.17 & 0.06 & 0.08 & 0.07 & 0.07 & 0.06 & 0.06 & 0.12 \\
\hline Big5_Agreeability & 0.16 & 0.06 & 0.05 & 0.07 & 0.03 & 0.05 & 0.06 & -0.10 \\
\hline Big5_Openness to experience & 0.10 & 0.12 & 0.11 & 0.11 & 0.10 & 0.11 & 0.13 & 0.10 \\
\hline Big5_Extroversion & -0.11 & -0.06 & -0.05 & -0.04 & 0.10 & -0.05 & -0.05 & 0.09 \\
\hline Big5_Conscientiousness & -0.07 & -0.08 & -0.08 & -0.07 & -0.08 & -0.06 & -0.10 & -0.04 \\
\hline Big5_Emotional stability & -0.07 & 0.05 & 0.02 & 0.07 & 0.05 & 0.07 & 0.08 & 0.07 \\
\hline \multicolumn{9}{|l|}{ Predictor } \\
\hline $\mathrm{PCV}^{\mathrm{a}}$ & & $-0.63 * * *$ & $-0.72 * * *$ & $-0.64 * * *$ & $-0.70 * * *$ & $-0.65 * * *$ & $-0.64 * * *$ & $-0.82 * * *$ \\
\hline \multicolumn{9}{|l|}{ Moderators } \\
\hline Cultural intelligence & & & $-0.12 *$ & & & & & -0.13 \\
\hline $\mathrm{PCV} \times \mathrm{CQ}^{\mathrm{b}}$ & & & $0.35 * * *$ & & & & & $0.37 * * *$ \\
\hline Previous IW Experience ${ }^{c}$ & & & & 0.04 & & & & -0.21 \\
\hline PCV $\times$ Previous IW Experience & & & & $0.16^{*}$ & & & & 0.15 \\
\hline Extent of $\mathrm{CCT}^{\mathrm{d}}$ & & & & & 0.02 & & & 0.24 \\
\hline $\mathrm{PCV} \times$ Extent of CCT & & & & & $0.22 *$ & & & -0.15 \\
\hline Length of the $\mathrm{IA}^{\mathrm{e}}$ & & & & & & -0.06 & & -0.04 \\
\hline PCV $\times$ Length of the IA & & & & & & -0.12 & 0.04 & 0.02 \\
\hline
\end{tabular}




\begin{tabular}{lllllllll} 
Cultural Distance & & & & & & $-0.15^{*}$ & 0.10 & -0.09 \\
$\mathrm{PCV} \times$ Cultural Distance & & & & & & & & \\
$\mathrm{R}^{2}$ & 0.08 & $0.46^{* * *}$ & $0.60^{* * *}$ & $0.48^{* * *}$ & $0.45^{* * *}$ & $0.47 * * *$ & $0.48^{* * *}$ & $0.57 * * *$ \\
$\mathrm{~N}$ & 168 & 168 & 168 & 168 & 85 & 168 & 168 & 85 \\
\hline
\end{tabular}

Notes: $\uparrow \mathrm{p}<0.1, * \mathrm{p}<.05, * * \mathrm{p}<.01, * * * \mathrm{p}<.001$

${ }^{\mathrm{a}} \mathrm{PCV}=$ Perceived Psychological Contract Violation, ${ }^{\mathrm{b}} \mathrm{CQ}=\mathrm{Cultural}$ Intelligence, ${ }^{\mathrm{c}}$ Previous IW Experience=Previous International Work Experience, ${ }^{\mathrm{d}}$ Extent of CCT=Extent of Cross-Cultural Training, ${ }^{\mathrm{e}}$ Length of the IA=Length of the International Assignment 
Table 4.3.

Hierarchical regressions predicting the impact of perceived psychological contract violation on turnover intentions

\begin{tabular}{|c|c|c|c|c|c|c|c|c|}
\hline \multirow[t]{2}{*}{ Dependent Variables } & \multicolumn{8}{|c|}{ Turnover Intentions } \\
\hline & Model 1 & Model 2 & Model 3 & Model 4 & Model 5 & Model 6 & Model 7 & Model 8 \\
\hline \multicolumn{9}{|l|}{ Controls } \\
\hline Age & 0.05 & -0.03 & -0.07 & -0.04 & 0.05 & -0.05 & -0.04 & 0.10 \\
\hline Gender & 0.01 & 0.08 & 0.07 & 0.07 & 0.09 & 0.08 & 0.06 & 0.04 \\
\hline Education & 0.00 & 0.01 & 0.01 & -0.004 & 0.00 & -0.01 & -0.01 & -0.05 \\
\hline Organizational tenure & 0.01 & -0.02 & -0.04 & -0.02 & -0.02 & -12.34 & -0.02 & 0.03 \\
\hline Host country language & -0.11 & 0.02 & -0.002 & 0.002 & 0.03 & 0.01 & 0.02 & -0.02 \\
\hline Big5_Agreeability & -0.06 & 0.05 & 0.06 & 0.04 & 0.02 & 0.06 & 0.06 & 0.23 \\
\hline Big5_Openness to experience & 0.16 & 0.13 & 0.15 & 0.15 & 0.18 & 0.15 & 0.13 & 0.17 \\
\hline Big5_Extroversion & 0.11 & 0.05 & 0.05 & 0.04 & 0.15 & 0.04 & 0.04 & 0.17 \\
\hline Big5_Conscientiousness & -0.06 & -0.05 & -0.06 & -0.06 & -0.08 & -0.06 & -0.04 & -0.16 \\
\hline Big5_Emotional stability & 0.02 & -0.11 & -0.09 & -0.14 & -0.15 & -0.14 & -0.15 & -0.24 \\
\hline \multicolumn{9}{|l|}{ Predictor } \\
\hline $\mathrm{PCV}^{\mathrm{a}}$ & & $0.69 * * *$ & $0.77 * * *$ & $0.71 * * *$ & $0.71 * * *$ & $0.71 * * *$ & $0.70 * * *$ & $0.77 * * *$ \\
\hline \multicolumn{9}{|l|}{ Moderators } \\
\hline Cultural intelligence & & & 0.09 & & & & & 0.23 \\
\hline $\mathrm{PCV} \times \mathrm{CQ}^{\mathrm{b}}$ & & & $-0.32 * * *$ & & & & & $-0.22 *$ \\
\hline Previous IW Experience ${ }^{c}$ & & & & -0.01 & & & & 0.09 \\
\hline PCV $\times$ Previous IW Experience & & & & $-0.21 * * *$ & & & & -0.41 \\
\hline Extent of $\mathrm{CCT}^{\mathrm{d}}$ & & & & & 0.14 & & & 0.33 \\
\hline $\mathrm{PCV} \times$ Extent of CCT & & & & & $-0.24 *$ & & & $0.59 \dagger$ \\
\hline Length of the $\mathrm{IA}^{\mathrm{e}}$ & & & & & & 0.01 & & 0.27 \\
\hline PCV $\times$ Length of the IA & & & & & & $0.18 * *$ & & 0.15 \\
\hline
\end{tabular}




\begin{tabular}{lllllllll} 
Cultural Distance & & & & & & & 0.04 & 0.13 \\
$\mathrm{PCV} \times$ Cultural Distance & & & & & & $0.20^{* *}$ & $0.26 \dagger$ \\
$\mathrm{R}^{2}$ & 0.02 & $0.47 * * *$ & $0.59 * * *$ & $0.51 * * *$ & $0.45^{* * *}$ & $0.50^{* * *}$ & $0.51^{* * *}$ & $0.58^{* * *}$ \\
$\mathrm{~N}$ & 168 & 168 & 168 & 168 & 85 & 168 & 168 & 85 \\
\hline
\end{tabular}

Notes: $\uparrow \mathrm{p}<0.1, * \mathrm{p}<.05, * * \mathrm{p}<.01, * * * \mathrm{p}<.001$

${ }^{\mathrm{a}} \mathrm{PCV}=$ Perceived Psychological Contract Violation, ${ }^{\mathrm{b}} \mathrm{CQ}=\mathrm{Cultural}$ Intelligence, ${ }^{\mathrm{c}}$ Previous IW Experience=Previous International Work Experience, ${ }^{\mathrm{d}}$ Extent of CCT=Extent of Cross-Cultural Training, ${ }^{\mathrm{e}}$ Length of the IA=Length of the International Assignment 
The regression results were highly significant and the R-squared value increased significantly from Model 1 to Model 2 in all regression analyses, indicating significant main effects of the perceived psychological contract violation over all expatriates' attitudes tested.

Specifically, Hypothesis 1a predicted that expatriates' perceived psychological contract violation would be negatively related to (i) job satisfaction and (ii) organizational commitment. As predicted, the perceived psychological contract violation significantly resulted in lowered job satisfaction (see Model 2 in Table 4.1, $\beta=-0.79, \mathrm{p}<.001$ ) and organizational commitment (see Model 2 in Table $4.2, \beta=-$ $0.63, \mathrm{p}<.001)$ in the expatriation context, even after accounting for controls.

Additionally, Hypothesis 1b suggested that expatriates' perceived psychological contract violation is expected to be positively associated with turnover intentions. In support of this hypothesis, the perceived psychological contract violation was found to be significantly related to turnover intentions of expatriates (see Model 2 in Table 4.3, $\beta=0.69, \mathrm{p}<.001$ ). These results are consistent with those found in the general employee population by other studies (Guzzo, Noonan, \& Elron, 1994; Turnley \& Feldman, 1998, 1999).

Next, to reveal the expected moderating effects, the interaction terms (i.e., cultural intelligence, previous international work experience, the extent of crosscultural training, length of the international assignment, and cultural distance) were entered into the regression equation in the third step. It is important to note that each interaction term was added to the model as a separate predictor variable. Thus, even 
though these were labeled as Model 3, 4, 5, 6, and 7 for the sake of convenience, it does not mean the sequential entry of interaction terms.

Hypothesis $2 \mathrm{a}$ was that cultural intelligence moderates the relations between perceived psychological contract and (i) job satisfaction and (ii) organizational commitment, such that the negative relationship diminishes when the expatriate possesses higher levels of cultural intelligence than when s/he possesses lower levels of cultural intelligence. Moreover, Hypothesis $2 \mathrm{~b}$ addressed that the expatriate's cultural intelligence moderates the relationship between perceived psychological contract violation and turnover intentions, such that the positive relationship decreases when the expatriate possesses higher levels of cultural intelligence than when s/he possesses lower levels of cultural intelligence.

Indeed, vis-à-vis those with lower cultural intelligence, culturally intelligent expatriates experienced a lesser decline both in job satisfaction (see Model 3 in Table $4.1, \beta=0.16, \mathrm{p}<.001$ ) and in organizational commitment (see Model 3 in Table 4.2, $\beta=0.35, \mathrm{p}<.001)$ following the perceived psychological contract violation.

Since the correlation between perceived psychological contract violation and job satisfaction and organizational commitment is negative, the positive beta indicates that the interaction between perceived psychological contract violation and cultural intelligence not simply reduced, but also canceled out the negative impacts of perceived psychological contract violation on job satisfaction and organizational commitment. 
In other words, cultural intelligence, as a moderator, not only changed the magnitude of the relationship between perceived psychological contract violation and each dependent variable, but also altered the direction of that relationship.

In addition, highly culturally competent expatriates were less likely than those with lower levels of cultural intelligence to intend to quit the international assignment when faced with perceived psychological contract violation (see Model 3 in Table 4.3, $\beta=-0.32, \mathrm{p}<.001)$. Again, because the correlation between perceived psychological contract violation and turnover intentions is positive, the negative beta indicates that the interaction between perceived psychological contract violation and cultural intelligence not simply reduced, but also neutralized the main positive effects of perceived psychological contract violation on turnover intentions.

Hypothesis 3a was that the expatriate's previous international work experience moderates the relationship between perceived psychological contract violation and (i) job satisfaction and (ii) organizational commitment, such that the negative relationship diminishes when the expatriate possesses longer previous international work experiences than when s/he possesses shorter previous international work experiences. Furthermore, Hypothesis $3 \mathrm{~b}$ suggested that the expatriate's previous international work experience moderates the relationship between perceived psychological contract violation and turnover intentions, such that the positive relationship decreases when the expatriate possesses longer previous international work experiences than when s/he possesses shorter international work experiences. 
The empirical results show that expatriates who have longer previous international work experience reported a lesser decline in job satisfaction (see Model 4 in Table 4.1, $\beta=0.08, \mathrm{p}<0.1$ ) and organizational commitment (see Model 4 in Table $4.2, \beta=0.16, \mathrm{p}<.05)$ in the event of perceived psychological contract violation compared to those with shorter previous international work experience. Therefore, previous international work experience not only reduced significantly, but also offset the adverse impacts of perceived psychological contract violation on job satisfaction and organizational commitment of expatriates.

Further, expatriates with longer previous international work experience were less likely to reflect the propensity for turnover than those who have little overseas work experience when the perceived psychological contract violation does occur (see Model 4 in Table 4.3, $\beta=-0.21, \mathrm{p}<.001)$. Specifically, the interaction between perceived psychological contract violation and previous international work experience substituted the main positive effects of perceived psychological contract violation on turnover intentions.

Hypothesis 4a suggested that the extent of cross-cultural training moderates the relationship between perceived psychological contract violation and (i) job satisfaction and (ii) organizational commitment, such that the negative relationship diminishes when cross-cultural training was provided to the expatriate to a larger extent than when it was provided to him or her to a lesser extent. In addition, Hypothesis $4 \mathrm{~b}$ was that the extent of cross-cultural training moderates the relationship between psychological contract violation and turnover intentions, such that the 
positive relationship decreases when cross-cultural training was provided to the expatriate to a larger extent than when it was provided to him or her to a lesser extent.

As seen in Model 5 in Table 4.1, the extent of cross-cultural training had no significant moderating effect on the relationship between perceived psychological contract violation and job satisfaction. More particularly, perceived psychological contract violation is negatively related to job satisfaction; yet, this relationship does not change depending on the extent to which cultural training was provided.

These results may be a consequence of small sample sizes. Slightly more than half of the participants $(\mathrm{N}=85)$ received cross-cultural training. In fact, despite its importance, not every expatriate is trained possibly because of the cost of the programs (Black, Mendenhall, \& Oddu, 1991; Britt, 2002; Deshpande \& Viswesvaran, 1992; Forster, 2000; Ho, 2012; Joshua-Gojer, 2012; Selmer, 2001; Tung, 1988; Zakaria, 2000).

Another plausible interpretation of the findings is that cross-cultural training that the participants received might place a strong emphasis on a narrow scope of cultural competence, such as foreign language or communication techniques; as such, it might not have addressed the deeper implications of the cross-cultural training in the psychological contract. Accordingly, it can be concluded that cross-cultural training providing a superficial understanding of culture does not moderate the impacts of perceived psychological contract violation on expatriates' job satisfaction.

The results of regression analysis further show that the interaction between the extent of cross-cultural training and perceived psychological contract violation produced a model which suggests that the extent of cross-cultural training moderates 
the impacts of perceived psychological contract violation both on organizational commitment (see Model 5 in Table 4.2, $\beta=0.22, \mathrm{p}<.05$ ) and turnover intentions (see Model 5 in Table 4.3, $\beta=-0.24, \mathrm{p}<.05)$. In particular, the extent of cross-cultural training, as a moderator, not only reduced the strength of the impacts of perceived psychological contract violation on each dependent variable, but also changed the direction of that association. In summary, the empirical evidence partially supports Hypothesis 4a and strongly supports Hypothesis $4 \mathrm{~b}$.

Hypothesis 5a was that the length of the international assignment moderates the relationship between perceived psychological contract violation and (i) job satisfaction and (ii) organizational commitment, such that the negative relationship diminishes when the length of the international assignment is shorter than when it is longer. Moreover, Hypothesis $5 \mathrm{~b}$ addressed that the length of the international assignment moderates the relationship between perceived psychological contract violation and turnover intentions, such that the positive relationship decreases when the length of the international assignment is shorter than when it is longer.

Unexpectedly, the length of the international assignment did not moderate the relation between perceived psychological contract violation and organizational commitment (see Model 6 in Table 4.2). This result may be explained by several factors.

One possible explanation is that since expatriates who are assigned to traditional long-term assignments are in general older than those who are assigned to temporary assignments (Maurer, 2013). In this sense, older employees are thought to be more loyal and committed to their organizations (Allen \& Meyer, 1993; Angle \& 
Perry, 1983; Hrebiniak \& Alutto, 1972; Sheldon, 1971). Taken together, the organizational commitment of expatriates who undertake long-term international assignments is less intensely harmed in the presence of perceived psychological contract violation.

On the one hand, the length of the international assignment moderated the correlation between perceived psychological contract violation and job satisfaction (see Model 6 in Table 4.1, $\beta=-0.13, \mathrm{p}<.01$ ) and turnover intentions (see Model 6 in Table 4.3, $\beta=0.18, \mathrm{p}<0.1)$. However, the moderating effect was in the opposite direction from what was expected from $\mathrm{H} 5 \mathrm{a}(\mathrm{i})$ and $\mathrm{H} 5 \mathrm{~b}$.

Specifically, the negative association between perceived psychological contract violation and job satisfaction diminished when the length of the international assignment increased. In addition, the positive association between perceived psychological contract violation and turnover intentions decreased, as the length of the international assignment increased. In summary, Hypothesis 5a is partially supported and Hypothesis 5b is marginally supported by the data, but in the opposite direction.

Hypothesis 6a was that cultural distance moderates the relationship between perceived psychological contract violation and (i) job satisfaction and (ii) organizational commitment, such that the negative relationship diminishes when the cultural distance between home and host countries is smaller than when it is larger. Additionally, Hypothesis 6b suggested that cultural distance moderates the relationship between perceived psychological contract violation and turnover 
intentions, such that the positive relationship decreases when the cultural distance between home and host countries is smaller than when it is larger.

Unexpectedly, the regression postulates the presence of opposite direction of the moderating role of cultural distance on the relationship between perceived psychological contract violation and job satisfaction (see Model 7 in Table 4.1, $\beta=-$ $0.14, \mathrm{p}<.01$ ), organizational commitment (see Model 7 in Table 4.2, $\beta=-0.15, \mathrm{p}$ $<.05$ ), and turnover intentions (see Model 7 in Table 4.3, $\beta=0.2, \mathrm{p}<.01$ ). More particularly, the negative relationship between perceived psychological contract violation and job satisfaction and organizational commitment diminished when cultural distance increased. Besides, the positive relationship between perceived psychological contract violation and turnover intentions decreased, as cultural distance increased.

The opposite moderating roles of both the length of the international assignment and the cultural distance can be attributed to other contextual features or theoretical boundary conditions of the study that are not previously recognized. Therefore, further research is needed.

Lastly, all candidate variables were included in the final model (Model 8). Table 5 summarizes the research hypotheses and hypotheses testing results. 
Table 5.

A summary of research hypotheses and test results

\begin{tabular}{|c|c|c|c|}
\hline No. & The hypotheses & Test resultis & $\beta$ and $p$-Value \\
\hline H1a & $\begin{array}{l}\text { Perceived psychological contract violation negatively relates to (i) job satisfaction } \\
\text { and (ii) organizational commitment. }\end{array}$ & Strongly supported & $\begin{array}{l}\text { (i) } \beta=-0.79, \mathrm{p}<.001 \\
\text { (ii) } \beta=-0.63, \mathrm{p}<.001\end{array}$ \\
\hline $\mathrm{H} 1 \mathrm{~b}$ & Perceived psychological contract violation positively relates to turnover intentions. & Strongly supported & $\beta=0.69, \mathrm{p}<.001$ \\
\hline $\mathrm{H} 2 \mathrm{a}$ & $\begin{array}{l}\text { Expatriate's cultural intelligence moderates the relationship between perceived } \\
\text { psychological contract violation and (i) job satisfaction and (ii) organizational } \\
\text { commitment, such that the negative relationship diminishes when the expatriate } \\
\text { possesses higher levels of cultural intelligence than when s/he possesses lower } \\
\text { levels of cultural intelligence. }\end{array}$ & Strongly supported & $\begin{array}{l}\text { (i) } \beta=0.16, \mathrm{p}<.001 \\
\text { (ii) } \beta=0.35, \mathrm{p}<.001\end{array}$ \\
\hline $\mathrm{H} 2 \mathrm{~b}$ & $\begin{array}{l}\text { Expatriate's cultural intelligence moderates the relationship between perceived } \\
\text { psychological contract violation and turnover intentions, such that the positive } \\
\text { relationship decreases when the expatriate possesses higher levels of cultural } \\
\text { intelligence than when s/he possesses lower levels of cultural intelligence. }\end{array}$ & Strongly supported & $\beta=-0.32, \mathrm{p}<.001$ \\
\hline $\mathrm{H} 3 \mathrm{a}$ & $\begin{array}{l}\text { Expatriate's previous international work experience moderates the relationship } \\
\text { between perceived psychological contract violation and (i) job satisfaction and (ii) } \\
\text { organizational commitment, such that the negative relationship diminishes when } \\
\text { the expatriate possesses longer previous international work experience than when } \\
\text { s/he possesses shorter previous international work experience. }\end{array}$ & $\begin{array}{l}\text { (i) Marginally supported } \\
\text { (ii) Strongly supported }\end{array}$ & $\begin{array}{l}\text { (i) } \beta=0.08, \mathrm{p}<0.1 \\
\text { (ii) } \beta=0.16, \mathrm{p}<.05\end{array}$ \\
\hline $\mathrm{H} 3 \mathrm{~b}$ & $\begin{array}{l}\text { Expatriate's previous international work experience moderates the relationship } \\
\text { between perceived psychological contract violation and turnover intentions, such } \\
\text { that the positive relationship decreases when the expatriate possesses longer } \\
\text { previous international work experience than when s/he possesses shorter } \\
\text { international work experience. }\end{array}$ & Strongly supported & $\beta=-0.21, \mathrm{p}<.001$ \\
\hline $\mathrm{H} 4 \mathrm{a}$ & $\begin{array}{l}\text { The extent of cross-cultural training moderates the relationship between perceived } \\
\text { psychological contract violation and (i) job satisfaction and (ii) organizational } \\
\text { commitment, such that the negative relationship diminishes when cross-cultural } \\
\text { training was provided to the expatriate to a larger extent than when it was provided } \\
\text { to him or her to a lesser extent. }\end{array}$ & Partially supported & $\begin{array}{l}\text { (i) no moderating effect } \\
\text { (ii) } \beta=0.22, \mathrm{p}<.05\end{array}$ \\
\hline
\end{tabular}




\begin{tabular}{|c|l|l|l|}
\hline $\mathrm{H} 4 \mathrm{~b}$ & $\begin{array}{l}\text { The extent of cross-cultural training moderates the relationship between perceived } \\
\text { psychological contract violation and turnover intentions, such that the positive } \\
\text { relationship decreases when cross-cultural training was provided to the expatriate } \\
\text { to a larger extent than when it was provided to him or her to a lesser extent. }\end{array}$ & Strongly supported \\
\hline $\mathrm{H} 5 \mathrm{a}$ & $\begin{array}{l}\text { The length of the international assignment moderates the relationship between } \\
\text { perceived psychological contract violation and (i) job satisfaction and (ii) } \\
\text { organizational commitment, such that the negative relationship diminishes when } \\
\text { the length of the international assignment is shorter than when it is longer. }\end{array}$ & $\begin{array}{l}\text { The test result for (i) } \\
\text { is significant but in } \\
\text { the opposite } \\
\text { direction. }\end{array}$ & $\begin{array}{l}\text { (i) } \beta=-0.13, \mathrm{p}<.01 \\
\text { (ii) no moderating effect }\end{array}$ \\
\hline $\mathrm{H} 5 \mathrm{~b}$ & $\begin{array}{l}\text { The length of the international assignment moderates the relationship between } \\
\text { perceived psychological contract violation and turnover intentions, such that the } \\
\text { positive relationship decreases when the length of the international assignment is } \\
\text { shorter than when it is longer. }\end{array}$ & $\begin{array}{l}\text { The test result is } \\
\text { significant but in the } \\
\text { opposite direction. }\end{array}$ & $\beta=0.18, \mathrm{p}<0.1$ \\
\hline $\mathrm{H} 6 \mathrm{a}$ & $\begin{array}{l}\text { Cultural distance between home and host countries moderates the relationship } \\
\text { between perceived psychological contract violation and (i) job satisfaction and (ii) } \\
\text { organizational commitment, such that the negative relationship diminishes when } \\
\text { the cultural distance between home and host countries is smaller than when it is } \\
\text { larger. }\end{array}$ & $\begin{array}{l}\text { The test results are } \\
\text { significant but in the } \\
\text { opposite direction. }\end{array}$ & $\begin{array}{l}\text { (i) } \beta=-0.14, \mathrm{p}<.01 \\
\text { (ii) } \beta=-0.15, \mathrm{p}<.05\end{array}$ \\
\hline $\mathrm{H} 6 \mathrm{~b}$ & $\begin{array}{l}\text { Cultural distance between home and host countries moderates the relationship } \\
\text { between perceived psychological contract violation and turnover intentions, such } \\
\text { that the positive relationship decreases when the cultural distance between home } \\
\text { and host countries is smaller than when it is larger. }\end{array}$ & $\begin{array}{l}\text { The test result is } \\
\text { significant but in the } \\
\text { opposite direction. }\end{array}$ & $\beta=0.2, \mathrm{p}<.01$ \\
\hline
\end{tabular}




\section{CHAPTER V: DISCUSSION}

This closing chapter summarizes key findings and explores how these findings contribute to the fundamental understanding of the psychological contract in the multi-layered context of expatriation. Also, the chapter points out some limitations of this dissertation followed by the possible directions for future research.

\section{Discussion}

In spite of a growing recognition of its importance in expatriate management, the psychological contract has not yet been sufficiently studied in the context of expatriation vis-à-vis the domestic context.

Considering that the expatriate employment relationship is deeply embedded in multiple contexts, the psychological contracts of expatriates are distinguished from those of domestic employees. Specifically, although the expatriate employment relationship is formed between the expatriate and the parent company of the MNE, it often remains, in effect, under the influence of the subsidiary's practices that are governed by the host country's contexts. As a consequence, both the parent company and the subsidiary may represent the employer's view of the psychological contract. Furthermore, the host country's cultures inevitably influence the psychological contract of expatriates.

The psychological contract is particularly important to expatriates owing to uncertainty entrenched in the expatriation context. In addition, there is little separation between their professional and personal lives during expatriation; as such, 
expatriates are likely to count on perceived promises alluded to in the psychological contract (Guzzo, Noonan, \& Elron, 1994; McNulty, 2014).

Nevertheless, as stated above, there has been a relative paucity of work on this subject. Accordingly, research exploring the expatriates' psychological contracts would vastly increase the current understanding of psychological contracts by broadening its application beyond the domestic employee-employer relationship. It also provides relevant insight into expatriate management.

In this vein, the primary purpose of this dissertation is two-fold. First, this dissertation attempted to empirically examine the effects of perceived psychological contract violation on expatriates' attitudes (i.e., job satisfaction, organizational commitment, and turnover intentions). Second, this dissertation aimed to investigate the moderating effects of individual, organizational, and national factors on the relationship between perceived psychological contract violation and expatriates' attitudes.

The findings of this dissertation ascertain that expatriates who perceive a violation of their psychological contract had significantly lower job satisfaction and commitment to the MNE, with higher levels of turnover intentions. These are consistent with findings of previous studies showing an association between perceived psychological contract violation and employees' attitudes in domestic settings (Zhao, Wayne, Glibkowski, \& Bravo, 2007).

In particular, the correlation between perceived psychological contract violation and job satisfaction was high $(\beta=-0.79, \mathrm{p}<.001)$, indicating that 
perceptions that the MNE has failed to fulfill its promises is related strongly to a decrease of job satisfaction of expatriates.

These results are in line with social exchange theory and equity theory that are regulated by the norm of reciprocity (Blau, 1964). The main thrust of both theories is that people act on the expectation of reciprocal returns, which are comparable to the cost or effort of that action. Therefore, for example, employees give their loyalty to the organization, because they expect their organization to reciprocate with comparable rewards.

These expectations of reciprocal and equitable exchanges provide a basis for the employment relationship and are essential for understanding psychological contracts (Blau, 1964; Emerson, 1976; Homans, 1961; Kelley \& Thibaut, 1978).

However, both reciprocity and equity are not always guaranteed in practice and are occasionally broken. In this regard, perceived inequity and lack of reciprocity lead to serious negative consequences in the employment relationship. More particularly, when employees perceive that the relationship with their organization is not reciprocal and thereby is inequitable, they use negative strategies, such as worsening attitudes, in their attempts to restore equity.

Similarly, the findings in the present dissertation indicate that when expatriates perceived their psychological contract was violated, they reacted to this violation by altering their attitudes to negative ones (i.e., a decrease in both job satisfaction and organizational commitment and an increase in turnover intentions). In this way, expatriates are able to correct the perceived imbalance in the expatriate employment relationship (Coyle-Shapiro \& Kessler, 2000). 
Furthermore, the findings indicate that several factors were related to expatriate reactions to perceived psychological contract violation. Specifically, the evidence shows that perceived psychological contract violation hardly mattered among expatriates who were high in cultural intelligence, whereas it was clearly related to unwanted expatriates' attitudes (i.e., decreased job satisfaction and organizational commitment, and increased turnover intentions) for expatriates who were low in cultural intelligence. This suggests that culturally intelligent expatriates are better aware of the significant impact of culture during expatriation; in turn, they are capable of responding adequately to perceived violations of their psychological contract.

Additionally, the correlation between perceived psychological contract violation and expatriates' attitudes were weaker for those with longer previous international work experience. This means that previous international work experience acts as a buffer for expatriates in their current international assignment. Particularly, the knowledge and skills acquired from previous international work experiences buffer expatriates from the challenges of perceived psychological contract violation and help them rebound more quickly and effectively from its deleterious effects.

The findings from this dissertation also reveal that extensive cross-cultural training appeared to attenuate the damaging effects of perceived psychological contract violation on expatriates' attitudes, particularly organizational commitment and turnover intentions. This is because intensive cross-cultural training helps expatriates establish a precise understanding of the international assignment and 
develop a realistic psychological contract with their MNE. As such, expatriates who received cross-cultural training to a large extent are likely to better anticipate and proactively prepare for any perceived psychological contract violations and thereby react less intensely to it.

In sum, individual factors, including expatriate's cultural intelligence and his or her previous international work experience, and organizational factors, particularly the extent of cross-cultural training, neutralize the negative impacts of perceived psychological contract violation on expatriates' attitudes.

Unexpectedly, perceived violation of the psychological contract was less predictive of a variety of negative outcomes, particularly decreased job satisfaction and organizational commitment, among expatriates who were assigned to a long-term international assignment compared to those with a short-term international assignment. This suggests that long-term expatriates tend to be less sensitive to the occurrence of psychological contract violations.

The analysis of cultural distance also reveals a result opposite to that expected. In particular, perceived psychological contract violations inflicted severe damages on expatriates' attitudes surprisingly when the cultural distance between home and host countries was smaller. In other words, the cultural distance between two countries contributes to expatriates' tolerance and hence alleviates the negative effects of perceived psychological contract violations on their attitudes.

There could be many underlying reasons for these unexpected results. One possible reason is that longer-tenured or more mature employees would be more likely to be assigned to long-term international assignments, as they typically 
demonstrate greater loyalty and commitment to their MNEs (Maurer, 2013). In this sense, numerous studies have argued that longer-tenured or older employees tend to be more resistant to perceived psychological contract violation (Bal, Kooij, \& De Jong, 2013; Rousseau \& McLean Parks, 1993).

Moreover, a culturally distant destination not just involves greater uncertainty, but also raises awareness of cultural differences that may lead to perceptions of psychological contract violation.

\section{Implications}

\section{Research implications}

This dissertation contributes to existing literature on the psychological contract in at least four important ways. First, whereas previous psychological contract research has focused predominantly on the domestic employment relationship, the present dissertation extends its applications to various employment relationships. In particular, this dissertation delves into how perceptions of a psychological contract violation affects attitudinal outcomes in the expatriation context.

Second, there has been a lack of effort to investigate contextual variables that might influence and shape perceptions of the psychological contract (Kickul, Lester, \& Belgio, 2004). By examining the role of individual, organizational, and national factors as moderators in the relationship between perceived psychological contract violation and expatriates' attitudes, this dissertation addresses the various contexts which have to be taken into account. 
Third, much of the previous research examining the effects of psychological contracts has been conducted in western settings (Kickul, Lester, \& Belgio, 2004; Lester, Turnley, Bloodgood, \& Bolino, 2002; Li, Wong, \& Kim, 2016; Peng, Wong, \& Song, 2016; Restubog, Bordia, \& Tang, 2006; Westwood, Sparrow, \& Leung, 2001). Although these studies have made important contributions to the literature on psychological contracts, it is not enough to understand the psychological contract in a variety of settings (Cassar \& Briner, 2009; Doktor, Tung, \& Von Glinow, 1991; Rousseau, 1995; Rousseau \& Schalk, 2000). In this sense, the current dissertation contributes to filling a research gap by using an international sample of Korean expatriates.

Last but not least, by using social exchange theory and equity theory as theoretical frameworks, this dissertation extends the applicability of both theories beyond the domestic employment relationship.

\section{Managerial implications}

The greater uncertainty involved in expatriation leads to a greater reliance on the psychological contract. Moreover, along with the blurred boundaries between work and private lives, expatriates expect MNEs to respond to their wide variety of needs. These facts together imply that MNEs have greater and exceedingly complex responsibilities to expatriates.

While the small sample size may limit the generalizability of findings, this dissertation provides several critical implications for expatriate management practices. Concretely, to some extent, MNEs should consider selecting candidates 
who achieve a score of moderate to high on cultural intelligence. This is because they are more likely to understand what might happen during expatriation and hence better deal with the perceived psychological contract violations than those with low scores on cultural intelligence.

For similar reasons, it is important and beneficial for MNEs to ensure that candidates possess sufficient experience of international assignments during the recruitment process. The accumulated knowledge and skills through previous international work experience fosters their psychological resilience toward perceived psychological contract violations.

Moreover, cross-cultural training is often the first point of interaction between the expatriate and the MNE. Thus, the initial impression during the cross-cultural training forms the foundation of the psychological contract. This suggests that MNEs need to be active not only in identifying individual characteristics, but also in developing and implementing adequate cross-cultural training programs for expatriates (Turnley \& Feldman, 1999).

More particularly, in a situation in which candidates are newcomers and thus lack working experience in the field of expatriation, it would be worthwhile for MNEs to provide both informative and consultative cross-cultural training programs that enhance a more in-depth understanding of the complex nature of the expatriation, develop mutual perceptions of the exchanges, and curtail the negative effects of perceived violation in the psychological contract (Puck, Kittler, \& Wright, 2008; Waxin \& Panaccio, 2005). 
It is clear that expatriates' attitudes affect their behaviors. The evidence shows that expatriates who have a higher propensity to resign may take further actions, such as actual turnover (Tekleab \& Taylor, 2003; Turnley \& Feldman, 1999). Such behaviors of expatriates eventually determine the MNE performance (Antal, 2000; Brewster, Bonache, Cerdin, \& Suutari, 2014; Edstroem \& Galbright, 1977; Harzing, 1995; Jokinen, Brewster, \& Suutari, 2008; Shaffer \& Harrison, 1998; Shay \& Baack, 2006; Takeuchi, Yun, \& Tesluk, 2002; Wang \& Takeuchi, 2007). Thus, expatriates' attitudes are the key predictor of the success of an international assignment by understanding and effectively managing their psychological contracts.

\section{Limitations and directions for future research}

Although this dissertation yields valuable information regarding the effects of perceived psychological contract violations and potential moderators (i.e., individual, organizational, and national-level variables) of expatriates' attitudes (i.e., job satisfaction, organizational commitment, and turnover intentions), there are several limitations that raise opportunities for future research.

Firstly, the reciprocal nature of the psychological contract implies that there are two perspectives to the psychological contract: the employee and the employer (Dabos \& Rousseau, 2004; Tekleab \& Taylor, 2003). Therefore, to fully understand the psychological contract, which consists of the perceptions of both parties to the employment relationship (Guest \& Conway, 2002), studies should explore the psychological contract from the perspectives of both the employee and the employer (Lester, Turnley, Bloodgood, \& Bolino, 2002; Tekleab \& Taylor, 2003). Indeed, 
Chen, Tsui, and Zhong (2008) examined reactions to psychological contract breaches from two separate perspectives, that is, the employee's reactions and the employer's reactions.

Nonetheless, most previous research has focused on the employee's perspective and paid scant attention to understanding the employer's view of the psychological contract (Conway \& Briner, 2005; Cullinane \& Dundon, 2006; Guest, 2004; Tekleab \& Taylor, 2003). In line with those previous studies, this dissertation studied the effects of perceived psychological contract violation from the expatriate's perspective.

However, there may be perceptual discrepancies in terms of psychological contract violations between the employee and the employer, because psychological contracts represent how people interpret promises (Rousseau \& Wade-Benzoin, 1995).

Accordingly, re-examining psychological contract violations with the perspective of both the expatriate and the MNE can greatly extend existing understanding of the psychological contracts of expatriates.

Secondly, this dissertation focused on psychological contract violations as perceived by the expatriate, rather than on perceived psychological contract fulfillment. Similarly, much is known about the effects of perceived psychological contract violations (Hartmann \& Rutherford, 2015; Lester, Turnley, Bloodgood, \& Bolino, 2002; Li, Wong, \& Kim, 2016; Turnley \& Feldman, 1998, 2000), while many questions remain unanswered regarding the consequences of perceived psychological contract fulfillment (Castaing, 2006; Conway, Guest, \& Trenberth, 2011; Coyle- 
Shapiro \& Kessler, 2000; De Ruiter, Lub, Jansma, \& Blomme, 2016; Robinson \& Morrison, 1995; Steve Chi \& Chen, 2007; Wu \& Chen, 2015).

Moreover, most studies have treated psychological contract fulfillment and psychological contract violation as two ends of one continuum and thus used interchangeably. However, recent studies have argued that they should be investigated as two separate constructs (Bal, De Lange, Jansen, \& Van Der Velde, 2008; Bal, Kooij, \& De Jong, 2013; Conway \& Briner, 2005; Smith \& Hitt, 2005). In particular, Smith and Hitt (2005) found empirical evidence that psychological contract violation and psychological fulfillment are distinct constructs, although they are somewhat correlated. Taken together, clearly, further research is needed on the psychological contract fulfillment (De Ruiter, Lub, Jansma, \& Blomme, 2016).

Thirdly, as mentioned above, the relatively small sample size $(\mathrm{N}=168)$ may limit the interpretable power of the current results. Moreover, most of the participants in the current sample came from Asian countries, particularly South Korea, and most were highly educated; thus, there might be systematic differences in response styles. For instance, people from different countries may have different tendencies to respond to questionnaires, regardless of their actual content (Baumgartner \& Steenkamp, 2001; Harzing, Brown, Koster, \& Zhao, 2012; Sarstedt, Bengart, Shaltoni, \& Lehmann, 2017).

Indeed, due to the cultural emphasis on the group over the individual, Korean people are often reluctant to express negative feelings about their organization (Choi \& Choi, 2001; Liu \& McClure, 2001). Therefore, future studies with a larger sample 
size and more variation in nationalities would be valuable in further refining and elaborating the current findings.

A fourth limitation is related to the use of self-report questionnaires for assessing the variables of interest. According to previous studies, the extensive reliance on self-report measures might raise concerns about common method variance, which describes the measurement error that is compounded by the tendency of survey participants to provide socially desirable responses and favorable selfpresentation (Chang, Van Witteloostuijn, \& Eden, 2010; Crowne \& Marlowe, 1960; Podsakoff, MacKenzie, Lee, \& Podsakoff, 2003). This, in turn, often results in the artificially inflated correlations among measured variables.

However, this dissertation attempted to reduce the possibility of common method variance by measuring the independent and dependent variables separately at different times albeit a short time (Podsakoff, MacKenzie, Lee, \& Podsakoff, 2003). Additionally, the effects of common method variance are mostly trivial when it comes to measuring interaction (Siemsen, Roth, \& Oliveira, 2010). As such, it is reasonable to assume here that common method bias only scarcely influenced the current findings.

Nevertheless, further research would benefit from adopting more objective measurements, in place of subjective self-reporting measures, to reduce the probability of common method variance and hence increase the robustness of the findings (Wall \& Wood, 2005).

A fifth direction for future research involves qualitative approaches. Even though quantitative methods are common in psychological research, qualitative 
research methods (i.e., case studies, ethnographic studies), either alone or as multi methods studies, may lead to a better understanding of subtle nuances that exist in psychological contracts (Shapiro, Von Glinow, \& Xiao, 2007).

Sixth, whereas attitudinal outcomes examined in this dissertation (i.e., job satisfaction, organizational commitment, and turnover intentions) are critical in expatriation, future studies can delve into other attitudinal variables as well as behavioral outcomes of perceived psychological contract violations (e.g., cultural adaptation, job performance, and actual turnover).

A final recommendation for future research would be to investigate the opposite moderating roles of both the length of the international assignment and the cultural distance. These unanticipated results may result from contextual attributes that have not previously been researched and thus deserve additional research investigation.

In line with this, it would be beneficial to explore the moderating role of other contextual factors (e.g., the parent company-subsidiary relationships and the host country's cultural attractiveness) on the relationship between perceived psychological contract violations and expatriate outcomes in order to develop a deep, precise understanding of psychological contracts in the expatriation context.

For example, unusually, two organizations - the parent company of the MNE and the foreign subsidiary - share the responsibility of delivering perceived promises in the expatriation context; yet, they may have different perspectives on that. In light of this, future studies could explore the influences of their different standpoints 
regarding psychological contracts on the relationship between perceived psychological contract violations and expatriate outcomes.

\section{Conclusion}

Grounded in social exchange theory and equity theory, the present dissertation attempts to answer questions pertaining to international human resource management when it comes to expatriation, such as 1) what impact does perceived psychological contract violation have on expatriates' attitudes? and 2) how do individual, organizational, and national factors influence the effects of perceived psychological contract violations on expatriates' attitudes?

Concretely, this dissertation aims to identify the relationship between perceived violation of psychological contracts and expatriates' attitudes as reflected in three dependent variables: job satisfaction, organizational commitment, and turnover intentions.

The dissertation findings reveal that perceived psychological contract violations have a negative influence on expatriates' job satisfaction and organizational commitment of expatriates, whereas it has a positive influence on their propensity to turn over.

Moreover, the present dissertation seeks to explore the moderating role of contextual factors on the relationship between perceived psychological contract violations and the three examined expatriates' attitudes.

Even though some were either marginally or partially significant, the findings

of this dissertation confirm the moderating effects of individual (e.g., cultural 
intelligence and previous international work experience) and organizational factors (e.g., the extent of cross-cultural training) on the existing relationship between perceived psychological contract violations and expatriates' attitudinal outcomes, including job satisfaction, organizational commitment, and turnover intentions. Additionally, despite the opposite direction, the findings show that both the length of the international assignment and the cultural distance moderate the effects of perceived psychological contract violations in the expatriation context.

In line with these findings, a number of studies have demonstrated that the relation between perceived psychological contract violations and work-related outcomes is moderated by contextual factors at three levels: the macro- (e.g., business and labor conditions), meso- (e.g., workplace environments), and micro-level factors (e.g., individual characteristics) (Pate, 2006; Scandura \& Sharif, 2014; Turnley \& Feldman, 1999).

As the economy becomes increasingly global and interconnected, so too do organizations' activities (Harrison \& Sin, 2005). In other words, albeit different in kind and degree, it has become imperative nowadays for most organizations to operate globally. Given the fact that a majority of MNEs are still heavily reliant on expatriates for critical functions abroad, expatriate management is crucial to MNEs in today’s global business environment.

In this context, this dissertation provides a timely and comprehensive picture of expatriate management by exploring the relation between perceived psychological contract violations and expatriates' attitudes, namely job satisfaction, organizational 
commitment, and turnover intentions, and by investigating the contextual moderators of this relationship at the individual, organizational, and national levels, respectively. 


\section{LIST OF REFERENCES}

Abe, H., \& Wiseman, R. L. (1983). A cross-cultural confirmation of the dimensions of intercultural effectiveness. International Journal of Intercultural Relations, 7(1), 53-67.

Adams, J. (1965). Inequity in social exchange. In L. Berkowitz (Ed.), Advances in Experimental Social Psychology (pp. 267-299). New York, N.Y.: Academic Press.

Adams, J. S. (1963). Towards an understanding of inequity. The Journal of Abnormal and Social Psychology, 67(5), 422-436.

Agho, A. O., Mueller, C. W., \& Price, J. L. (1993). Determinants of employee job satisfaction: An empirical test of a causal model. Human Relations, 46(8), 1007-1027.

Ainsworth, S., \& Purss, A. (2009). Same time, next year? Human resource management and seasonal workers. Personnel Review, 38(3), 217-235.

Akerlof, G. A., Rose, A. K., Yellen, J. L., Ball, L., \& Hall, R. E. (1988). Job switching and job satisfaction in the U.S. labor market. Brookings Papers on Economic Activity, 1988(2), 495-594.

Alderfer, C. P. (1969). An empirical test of a new theory of human needs. Organizational Behavior and Human Performance, 4(2), 142-175.

Aldossari, M., \& Robertson, M. (2016a). The role of wasta in repatriates' perceptions of a breach to the psychological contract: A Saudi Arabian case study. The International Journal of Human Resource Management, 27(16), 1854-1873.

Aldossari, M., \& Robertson, M. (2016b). Repatriation and the psychological contract: A Saudi Arabian comparative study. The International Journal of Human Resource Management, 1-28.

Allen, N. J., \& Meyer, J. P. (1993). Organizational commitment: Evidence of career stage effects?. Journal of Business Research, 26(1), 49-61.

Allen, N. J., \& Meyer, J. P. (1996). Affective, continuance, and normative commitment to the organization: An examination of construct validity. Journal of Vocational Behavior, 49(3), 252-276.

Allred, S. B., \& Ross-Davis, A. (2011). The drop-off and pick-up method: An approach to reduce nonresponse bias in natural resource surveys. Small-Scale Forestry, 10(3), 305318.

Andresen, M., \& Biemann, T. (2013). A taxonomy of internationally mobile managers. The International Journal of Human Resource Management, 24(3), 533-557. 
Angle, H. L., \& Perry, J. L. (1983). Organizational commitment: Individual and organizational influences. Work and Occupations, 10(2), 123-146.

Antal, A. B. (2000). Types of knowledge gained by expatriate managers. Journal of General Management, 26(2), 32-51.

Argyris, C. (1960). Understanding Organizational Behavior. Oxford, England: Dorsey.

Aryee, S., Luk, V., Leung, A., \& Lo, S. (1999). Role stressors, interrole conflict, and well-being: The moderating influence of spousal support and coping behaviors among employed parents in Hong Kong. Journal of Vocational Behavior, 54(2), 259-278.

Aselage, J., \& Eisenberger, R. (2003). Perceived organizational support and psychological contracts: A theoretical integration. Journal of Organizational Behavior, 24(5), 491-509.

Atkinson, C. (2007). Trust and the psychological contract. Employee Relations, 29(3), 227-246.

Avanzi, L., Fraccaroli, F., Sarchielli, G., Ullrich, J., \& van Dick, R. (2014). Staying or leaving: A combined social identity and social exchange approach to predicting employee turnover intentions. International Journal of Productivity and Performance Management, 63(3), 272-289.

Bal, P. M., De Lange, A. H., Jansen, P. G., \& Van Der Velde, M. E. (2008).

Psychological contract breach and job attitudes: A meta-analysis of age as a moderator. Journal of Vocational Behavior, 72(1), 143-158.

Bal, P. M., Kooij, D. T., \& De Jong, S. B. (2013). How do developmental and accommodative HRM enhance employee engagement and commitment? The role of psychological contract and SOC strategies. Journal of Management Studies, 50(4), 545572.

Barksdale, K., \& Werner, J. M. (2001). Managerial ratings of in-role behaviors, organizational citizenship behaviors, and overall performance: Testing different models of their relationship. Journal of Business Research, 51(2), 145-155.

Baruch, Y., \& Peiperl, M. (2003). An empirical assessment of Sonnenfeld's career systems typology. International Journal of Human Resource Management, 14(7), 12671283.

Baumgartner, H., \& Steenkamp, J. B. E. (2001). Response styles in marketing research: A cross-national investigation. Journal of Marketing Research, 38(2), 143-156. 
Becker, T. E. (2005). Potential problems in the statistical control of variables in organizational research: A qualitative analysis with recommendations. Organizational Research Methods, 8(3), 274-289.

Beechler, S., \& Woodward, I. C. (2009). The global "war for talent". Journal of International Management, 15(3), 273-285.

Bendix, S. (2010). Industrial Relations in South Africa. Cape Town, South Africa: Juta and Company Ltd.

Bennett, R., Aston, A., \& Colquhoun, T. (2000). Cross-cultural training: A critical step in ensuring the success of international assignments. Human Resource Management, 39(2, 3), 239-250.

Bhaskar-Shrinivas, P., Harrison, D. A., Shaffer, M. A., \& Luk, D. M. (2005). Input-based and time-based models of international adjustment: Meta-analytic evidence and theoretical extensions. Academy of Management Journal, 48(2), 257-281.

Birdseye, M. G., \& Hill, J. S. (1995). Individual, organizational/work and environmental influences on expatriate turnover tendencies: An empirical study. Journal of International Business Studies, 26(4), 787-813.

Black, J. S. (1988). Work role transitions: A study of American expatriate managers in Japan. Journal of International Business Studies, 19(2), 277-294.

Black, J. S., \& Gregersen, H. B. (1991). Antecedents to cross-cultural adjustment for expatriates in Pacific Rim assignments. Human Relations, 44(5), 497-515.

Black, J. S., \& Gregersen, H. B. (1999). The right way to manage expats. Harvard Business Review, 77(2), 52-59.

Black, J. S., \& Gregersen, H. B. (2007). The right way to manage expats. In M. Mendenhall, G. R. Oddoum, \& K. S. Gunter (Eds.), Reading and Cases in International Human Resource Management (pp. 119-128). New York, N.Y.: Routledge.

Black, J. S., Mendenhall, M., \& Oddou, G. (1991). Toward a comprehensive model of international adjustment: An integration of multiple theoretical perspectives. Academy of Management Review, 16(2), 291-317.

Black, J. S., \& Stephens, G. K. (1989). The influence of the spouse on American expatriate adjustment and intent to stay in Pacific Rim overseas assignments. Journal of Management, 15(4), 529-544.

Blau, P. M. (1964). Exchange and Power in Social Life. Piscataway, N.J.: Transaction Publishers. 
Bochner, S., Hutnik, N., \& Furnham, A. (1985). The friendship patterns of overseas and host students in an Oxford student residence. The Journal of Social Psychology, 125(6), 689-694.

Bochner, S., McLeod, B. M., \& Lin, A. (1977). Friendship patterns of overseas students: A functional model. International Journal of Psychology, 12(4), 277-294.

Bolino, M. C., Klotz, A. C., \& Turnley, W. H. (2016). The implications of turning down an international assignment: A psychological contracts perspective. The International Journal of Human Resource Management, 1-26.

Bonache, J., \& Brewster, C. (2001). Knowledge transfer and the management of expatriation. Thunderbird International Business Review, 43(1), 145-168.

Bonache, J., \& Zárraga-Oberty, C. (2008). Determinants of the success of international assignees as knowledge transferors: A theoretical framework. The International Journal of Human Resource Management, 19(1), 1-18.

Brayfield, A. H., \& Rothe, H. F. (1951). An index of job satisfaction. Journal of Applied Psychology, 35(5), 307-311.

Brein, M., \& David, K. H. (1971). Intercultural communication and the adjustment of the Sojourner. Psychological Bulletin, 76(3), 215-230.

Breitenmoser, A., \& Berg, N. (2017). What do they Expect, and what do we need to offer? A classification of repatriation strategies from the MNC perspective. In B. Bader, T. Schuster, \& A. K. Bader (Eds.), Expatriate Management (pp. 191-224). London, England: Palgrave Macmillan.

Brewster, C., Bonache, J. A., Cerdin, J. L. \& Suutari, V. (2014). Exploring expatriate outcomes. International Journal of Human Resource Management, 25(14), 1921-1937.

Briscoe, D. R., \& Schuler, R. S. (2004). International Human Resource Management: Policy and Practice for the Global Enterprise. London, England: Routledge.

Brislin, R. W. (1976). Translation: Applications and Research. New York, N.Y.: Gardner Press.

Brislin. R. W. (1981). Cross-cultural encounters: Face-to-Face Interaction. New York, N.Y.: Pergamon.

Brislin, R. W., Worthley, R., \& Macnab, B. (2006). Cultural intelligence: Understanding behaviors that serve people's goals. Group \& Organization Management, 31(1), 40-55.

Britt, J. (2002). Expatriates want more support from home. HR Magazine, 47(7), 21-22. 
Brookfield Global Relocation Services. (2015). Global Mobility Trends Survey. Retrieved December 15, 2017, from http://www.brookfieldgrs.com

Brookfield Global Relocation Services. (2016). Global Mobility Trends Survey. Retrieved December 15, 2017, from http://www.brookfieldgrs.com

Buchanan, B. (1974). Building organizational commitment: The socialization of managers in work organizations. Administrative Science Quarterly, 19(4), 533-546.

Burke, R. J., \& Greenglass, E. (1995). A longitudinal study of psychological burnout in teachers. Human Relations, 48(2), 187-202.

Byrne, Z. S. (2005). Fairness reduces the negative effects of organizational politics on turnover intentions, citizenship behavior and job performance. Journal of Business and Psychology, 20(2), 175-200.

Caligiuri, P. M. (1997). Assessing expatriate success: Beyond just. Being There. In D. M. Saunders, \& Z. Aycan (Eds.), New Approaches to Employment Management (pp. 117140). Greenwich, C.T.: JAI Press.

Caligiuri, P. M. (2000). The big five personality characteristics as predictors of expatriate's desire to terminate the assignment and supervisor- rated performance. Personnel Psychology, 53(1), 67-88.

Caligiuri, P. M., Hyland, M. M., Joshi, A., \& Bross, A. S. (1998). Testing a theoretical model for examining the relationship between family adjustment and expatriates' work adjustment. Journal of Applied Psychology, 83(4), 598-614.

Caligiuri, P. M., \& Lazarova, M. (2002). A model for the influence of social interaction and social support on female expatriates' cross-cultural adjustment. International Journal of Human Resource Management, 13(5), 761-772.

Caligiuri, P. M., \& Phillips, J. M. (2003). An application of self-assessment realistic job previews to expatriate assignments. International Journal of Human Resource Management, 14(7), 1102-1116.

Campbell, J. P., \& Pritchard, R. D. (1976). Motivation theoryin industrial and organizational psychology. In M. Dunnette (Ed.), Handbook of Industrial and Organizational Psychology (pp. 63-130). Chicago, I.L.: Rand McNally.

Carr, S. C., Inkson, K., \& Thorn, K. (2005). From global careers to talent flow: Reinterpreting 'brain drain'. Journal of World Business, 40(4), 386-398.

Carraher, S. M., Sullivan, S. E., \& Carraher, S. C. (2005). An examination of the stress experienced by entrepreneurial expatriate health care professionals working in Benin, 
Bolivia, Burkina Faso, Ethiopia, Ghana, Niger, Nigeria, Paraguay, South Africa and Zambia. International Journal of Entrepreneurship, 9, 45-66.

Carstensen, L. L., Isaacowitz, D. M., \& Charles, S. T. (1999). Taking time seriously: A theory of socioemotional selectivity. American Psychologist, 54(3), 165-181.

Casado, R., \& Caspersz, D. (2016). From 'opportunity' to 'insecurity': The psychological contract of highly skilled immigrants in Western Australia. Labour \& Industry, 26(3), 190-202.

Cassar, V., \& Briner, R. (2009). Contextualizing the features of the psychological contract: The case of Malta. Journal of Managerial Psychology, 24(7), 677-694.

Castaing, S. (2006). The effects of psychological contract fulfilment and public service motivation on organizational commitment in the French civil service. Public Policy and Administration, 21(1), 84-98.

Cavusgil, S. T., \& Knight, G. (2009). Born Global Firms: A New International Enterprise. New York, N.Y.: Business Expert Press.

Chadwick-Jones, J. K. (1976). Social Exchange Theory: Its Structure and Influence in Social Psychology. London, England: Academic Press.

Chang, S. J., Van Witteloostuijn, A., \& Eden, L. (2010). From the editors: Common method variance in international business research. Journal of International Business Studies, 41(2), 178-184.

Chang, Y. Y., Gong, Y., \& Peng, M. W. (2012). Expatriate knowledge transfer, subsidiary absorptive capacity, and subsidiary performance. Academy of Management Journal, 55(4), 927-948.

Chen, Y. R., Chen, X. P., \& Portnoy, R. (2009). To whom do positive norm and negative norm of reciprocity apply? Effects of inequitable offer, relationship, and relational-self orientation. Journal of Experimental Social Psychology, 45(1), 24-34.

Chen, Z. X., Tsui, A. S., \& Zhong, L. (2008). Reactions to psychological contract breach: A dual perspective. Journal of Organizational Behavior, 29(5), 527-548.

Chmiel, N., Fraccaroli, F., \& Sverke, M. (2017). An Introduction to Work and Organizational Psychology: An International Perspective. New York, N.Y.: John Wiley \& Sons.

Choi, S. C., \& Choi, S. H. (2001). Cheong: The socioemotional grammar of Koreans. International Journal of Group Tensions, 30(1), 69-80.

Church, A. T. (1982). Sojourner adjustment. Psychological Bulletin, 91(3), 540-572. 
Claus, L., Lungu, A. P., \& Bhattacharjee, S. (2011). The effects of individual, organizational and societal variables on the job performance of expatriate managers. International Journal of Management, 28(1), 249-271.

Collings, D. G., McDonnell, A., Gunnigle, P., \& Lavelle, J. (2010). Swimming against the tide: Outward staffing flows from multinational subsidiaries. Human Resource Management, 49(4), 575-598.

Collings, D. G., Scullion, H., \& Dowling, P. J. (2009). Global staffing: A review and thematic research agenda. The International Journal of Human Resource Management, 20(6), 1253-1272.

Collings, D. G., Scullion, H., \& Morley, M. J. (2007). Changing patterns of global staffing in the multinational enterprise: Challenges to the conventional expatriate assignment and emerging alternatives. Journal of World Business, 42(2), 198-213.

Conway, N., \& Briner, R. B. (2002). A daily diary study of affective responses to psychological contract breach and exceeded promises. Journal of Organizational Behavior, 23(3), 287-302.

Conway, N., \& Briner, R. B. (2005). Understanding Psychological Contracts at work: A Critical Evaluation of Theory and Research. Oxford, England: Oxford University Press.

Conway, N., Guest, D., \& Trenberth, L. (2011). Testing the differential effects of changes in psychological contract breach and fulfillment. Journal of Vocational Behavior, 79(1), 267-276.

Cook, K. S., \& Emerson, R. M. (1978). Power, equity and commitment in exchange networks. American Sociological Review, 43(5), 721-739.

Cook, K. S., \& Emerson, R. M. (1984). Exchange networks and the analysis of complex organizations. Research in the Sociology of Organizations, 3(4), 1-30.

Cook, V. (2013). Second Language Learning and Language Teaching. Abingdon, N.Y.: Routledge.

Copeland, L. (1985). Going International: How to Make Friends and Deal Effectively in the Global Marketplace. New York, N.Y.: Plume.

Costen, W. M., \& Salazar, J. (2011). The impact of training and development on employee job satisfaction, loyalty, and intent to stay in the lodging industry. Journal of Human Resources in Hospitality \& Tourism, 10(3), 273-284.

Cousins, K. C., Robey, D., \& Zigurs, I. (2007). Managing strategic contradictions in hybrid teams. European Journal of Information Systems, 16(4), 460-478. 
Coyle-Shapiro, J. A. M., \& Conway, N. (2005). Exchange relationships: Examining psychological contracts and perceived organizational support. Journal of Applied Psychology, 90(4), 774-781.

Coyle- Shapiro, J. A. M., \& Kessler, I. (2000). Consequences of the psychological contract for the employment relationship: A large scale survey. Journal of Management Studies, 37(7), 903-930.

Coyle-Shapiro, J. A. M., \& Kessler, I. (2002). Exploring reciprocity through the lens of the psychological contract: Employee and employer perspectives. European Journal of Work and Organizational Psychology, 11(1), 69-86.

Coyle-Shapiro, J. A. M., \& Parzefall, M. (2008). Psychological contracts. In Cooper, C. L., \& Barling, J. (Eds.), The SAGE Handbook of Organizational Behavior (pp. 17-34). London, England: Sage.

Cropanzano, R., \& Mitchell, M. S. (2005). Social exchange theory: An interdisciplinary review. Journal of Management, 31(6), 874-900.

Crowley-Henry, M. (2007). The protean career: Exemplified by first world foreign residents in Western Europe?. International Studies of Management \& Organization, 37(3), 44-64.

Crowne, D. P., \& Marlowe, D. (1960). A new scale of social desirability independent of psychopathology. Journal of Consulting Psychology, 24(4), 349-354.

Cui, G., \& Awa, N. E. (1992). Measuring intercultural effectiveness: An integrative approach. International Journal of Intercultural Relations, 16(3), 311-328.

Cui, G., \& Van Den Berg, S. (1991). Testing the construct validity of intercultural effectiveness. International Journal of Intercultural Relations, 15(2), 227-240.

Cullinane, N., \& Dundon, T. (2006). The psychological contract: A critical review. International Journal of Management Reviews, 8(2), 113-129.

Dabos, G. E., \& Rousseau, D. M. (2004). Mutuality and reciprocity in the psychological contracts of employees and employers. Journal of Applied Psychology, 89(1), 52-72.

Dawson, G. S., Karahanna, E., \& Buchholtz, A. (2013). A study of psychological contract breach spillover in multiple-agency relationships in consulting professional service firms. Organization Science, 25(1), 149-170.

De Cuyper, N., \& De Witte, H. (2006). The impact of job insecurity and contract type on attitudes, well- being and behavioural reports: A psychological contract perspective. Journal of Occupational and Organizational Psychology, 79(3), 395-409. 
De Cuyper, N., \& De Witte, H. (2007). Job insecurity in temporary versus permanent workers: Associations with attitudes, well-being, and behaviour. Work \& Stress, 21(1), 65-84.

De Hauw, S., \& De Vos, A. (2010). Millennials' career perspective and psychological contract expectations: does the recession lead to lowered expectations?. Journal of Business and Psychology, 25(2), 293-302.

De Jong, J., Schalk, R., \& De Cuyper, N. (2009). Balanced versus unbalanced psychological contracts in temporary and permanent employment: Associations with employee attitudes. Management and Organization Review, 5(3), 329-351.

Delios, A., \& Bjorkman, I. (2000). Expatriate staffing in foreign subsidiaries of Japanese multinational corporations in the PRC and the United States. International Journal of Human Resource Management, 11(2), 278-293.

De Ruiter, M., Lub, X., Jansma, E., \& Blomme, R. J. (2016). Psychological contract fulfillment and expatriate intrinsic career success: The mediating role of identification with the multinational corporation. The International Journal of Human Resource Management, 1-28.

Desatnick, R. L., \& Bennett, M. L. (1978). Human Resource Management in the Multinational Company. New York, N.Y.: Nichols Publishing Co.

Deshpande, S. P., \& Viswesvaran, C. (1992). Is cross-cultural training of expatriate managers effective: A meta analysis. International Journal of Intercultural Relations, $16(3), 295-310$.

Donaldson, B., \& O’Toole, T. (2007). Strategic Market Relationships: From Strategy to Implementation. London, England: John Wiley \& Sons.

Dow, D., \& Karunaratna, A. (2006). Developing a multidimensional instrument to measure psychic distance stimuli. Journal of International Business Studies, 37(5), 578602.

Dowling, P. J., \& Welch, D. E. (2004). International Human Resource Management: Managing People in an International Context. London, England: Thompson Learning.

Downes, M., \& Thomas, A. S. (2000). Knowledge transfer through expatriation: The Ucurve approach to overseas staffing. Journal of Managerial Issues, 12(2), 131-149.

Druker, J., \& Stanworth, C. (2004). Mutual expectations: A study of the three- way relationship between employment agencies, their client organisations and white- collar agency 'temps'. Industrial Relations Journal, 35(1), 58-75. 
Dunbar, E. (1992). Adjustment and satisfaction of expatriate U.S. personnel.

International Journal of Intercultural Relations, 16(1), 1-16.

Earley, P. C. (1987). Intercultural training for managers: A comparison of documentary and interpersonal methods. Academy of Management Journal, 30(4), 685-698.

Earley, P. C., \& Ang, S. (2003). Cultural Intelligence: Individual Interactions Across Cultures. Stanford, C.A.: Standard University Press.

Eckerd, S., Hill, J., Boyer, K. K., Donohue, K., \& Ward, P. T. (2013). The relative impact of attribute, severity, and timing of psychological contract breach on behavioral and attitudinal outcomes. Journal of Operations Management, 31(7), 567-578.

Edström, A., \& Galbraith, J. R. (1977). Transfer of managers as a coordination and control strategy in multinational organizations. Administrative Science Quarterly, 22(2), 248-263.

Eisenberger, R., Huntington, R., Hutchison, S., \& Sowa, D. (1986). Perceived organizational support. Journal of Applied Psychology, 71(3), 500-507.

Elangovan, A. R. (2001). Causal ordering of stress, satisfaction and commitment, and intention to quit: A structural equations analysis. Leadership \& Organization Development Journal, 22(4), 159-165.

Emerson, R. M. (1976). Social exchange theory. Annual Review of Sociology, 2(1), 335362.

Employee Benefit Plan Review. (2001). Survey of expatriates shows differing employeremployee perceptions. Employee Benefit Plan Review, 55(12), 40-41.

Evans, J., \& Mavondo, F. T. (2002). Psychic distance and organizational performance: An empirical examination of international retailing operations. Journal of International Business Studies, 33(3), 515-532.

Evans, P., Pucik, V., \& Barsoux, J. L. (2002). The Global Challenge. Boston, M.A.: McGraw-Hill.

Farndale, E., Pai, A., Sparrow, P., \& Scullion, H. (2014). Balancing individual and organizational goals in global talent management: A mutual-benefits perspective. Journal of World Business, 49(2), 204-214.

Festing, M., \& Schäfer, L. (2014). Generational challenges to talent management: A framework for talent retention based on the psychological-contract perspective. Journal of World Business, 49(2), 262-271. 
Festinger, L. (1962). A Theory of Cognitive Dissonance. Stanford, C.A.: Stanford University Press.

Finaccord. (2014). Global Expatriates. Retrieved December 15, 2017, from http://www.finaccord.com/press-release_2014_global-expatriates_-size-segmentationand-forecast-for-the-worldwide-market.htm

Fishbein, M., \& Ajzen, I. (1975). Belief, Attitude, Intention, and Behavior: An Introduction to Theory and Research. Reading, M.A.: Addison-Wesley.

Fiske, A. P. (1992). The four elementary forms of sociality: Framework for a unified theory of social relations. Psychological Review, 99(4), 689-723.

Florkowski, G. W., \& Fogel, D. S. (1999). Expatriate adjustment and commitment: The role of host-unit treatment. International Journal of Human Resource Management, 10(5), 783-807.

Forster, N. (1997). The persistent myth of high expatriate failure rates: A reappraisal. International Journal of Human Resource Management, 8(4), 414-433.

Forster, N. (2000). Expatriates and the impact of cross- cultural training. Human Resource Management Journal, 10(3), 63-78.

Freeman, R. B. (1980). The exit-voice tradeoff in the labor market: Unionism, job tenure, quits, and separations. The Quarterly Journal of Economics, 94(4), 643-673.

Froese, F. J. (2012). Motivation and adjustment of self-initiated expatriates: The case of expatriate academics in South Korea. The International Journal of Human Resource Management, 23(6), 1095-1112.

Froese, F. J., Kim, K., \& Eng, A. (2016). Language, cultural intelligence, and inpatriate turnover intentions: Leveraging values in multinational corporations through inpatriates. Management International Review, 56(2), 283-301.

Gail Lewis, K. (1997). Breakdown-a psychological contract for expatriates. European Business Review, 97(6), 279-293.

Gakovic, A., \& Tetrick, L. E. (2003). Psychological contract breach as a source of strain for employees. Journal of Business and Psychology, 18(2), 235-246.

Gedro, J. (2010). The lavender ceiling atop the global closet: Human resource development and lesbian expatriates. Human Resource Development Review, 9(4), 385404.

Geurts, S. A., Schaufeli, W. B., \& Rutte, C. G. (1999). Absenteeism, turnover intention and inequity in the employment relationship. Work \& Stress, 13(3), 253-267. 
Gibson, R. O. (1966). Toward a conceptualization of absence behavior of personnel in organization. Administrative Science Quarterly, 11(1), 107-133.

GMAC. (2004). Global Relocation Services. Retrieved December 15, 2017, from https://www.google.com/url?sa=t\&rct=j\&q=\&esrc=s\&source=web\&cd=1\&ved=0ahUKE wiIjs2Cv87ZAhWIwFMKHdYYB5wQFggnMAA\&url=http\%3A\%2F\%2Fwww.nftc.org $\% 2$ Fdefault $\% 2$ Fhr\%2FGRTS\%252020034.pdf\&usg=AOvVaw0jmsgLmKU_m83vTTFjtypP

Goby, V. P., Ahmed, Z. U., Annavarjula, M., Ibrahim, D. N., \& Osman-Gani, A. (2002). Determinants of expatriate success: An empirical study of Singaporean expatriates in the peoples Republic of China. Journal of Transnational Management Development, 7(4), 73-88.

Gong, Y. (2003). Subsidiary staffing in multinational enterprises: Agency, resources, and performance. Academy of Management Journal, 46(6), 728-739.

Gouldner, A. W. (1960). The norm of reciprocity: A preliminary statement. American Sociological Review, 25(2), 161-178.

Grant, A. M., \& Shin, J. (2012). Work motivation: Directing, energizing, and maintaining effort (and research). In R. M. Ryan (Ed.), The Oxford Handbook of Human Motivation (pp. 505-519). New York, N.Y.: Oxford University Press.

Greenberg, J. (1990). Employee theft as a reaction to underpayment inequity: The hidden cost of pay cuts. Journal of Applied Psychology, 75(5), 561-568.

Gregersen, H. B., \& Black, J. S. (1990). A multifaceted approach to expatriate retention in international assignments. Group \& Organization Studies, 15(4), 461-485.

Guerrero, S., \& Herrbach, O. (2008). The affective underpinnings of psychological contract fulfilment. Journal of Managerial Psychology, 23(1), 4-17.

Guest, D. E. (1998). Is the psychological contract worth taking seriously?. Journal of Organizational Behavior, 19(S1), 649-664.

Guest, D. E. (2004). The psychology of the employment relationship: An analysis based on the psychological contract. Applied Psychology, 53(4), 541-555.

Guest, D. E., \& Clinton, M. (2005). Contracting in the U.K.: Current research evidence on the impact of flexible employment an the nature of psychological contracts. In N. De Cuyper, K. Isaksson, \& H. De Witte (Eds.), Employment Contract and Well-Being Among European Workers (pp. 201-224). Hampshire, England: Ashgate. 
Guest, D. E., \& Conway, N. (1998). Fairness at Work and the Psychological Contract. London, England: Institute of Personal and Development.

Guest, D. E., \& Conway, N. (2002). Communicating the psychological contract: An employer perspective. Human Resource Management Journal, 12(2), 22-38.

Guest, D. E., Isaksson, K., \& De Witte, H. (2010). Employment Contracts, Psychological Contracts, and Worker Well-Being: An International Study. Oxford, England: Oxford University Press.

Guest, D. E., Mackenzie Davey, K., \& Patch, A. (2003). The Psychological Contracts, Attitudes and Behaviour of Workers on Temporary and Permanent Contracts. London, England: King's College.

Guzzo, R. A., Nelson, G. L., \& Noonan, K. A. (1992). Commitment and employer involvement in employees' nonwork lives. In S. Zedeck (Ed), Work, Families, and Organizations (pp. 236-271). San Francisco, C.A.: Jossey-Bass.

Guzzo, R. A., \& Noonan, K. A. (1994). Human resource practices as communications and the psychological contract. Human Resource Management, 33(3), 447-462.

Guzzo, R. A., Noonan, K. A., \& Elron, E. (1994). Expatriate managers and the psychological contract. Journal of Applied Psychology, 79(4), 617-626.

Haggard, D. L. (2012). Mentoring and psychological contract breach. Journal of Business and Psychology, 27(2), 161-175.

Hall, D. T., \& Moss, J. E. (1998). The new protean career contract: Helping organizations and employees adapt. Organizational Dynamics, 26(3), 22-37.

Harris P. R., \& Moran R. T. (1987). Managing Cultural Differences: High Performance strategies for Todays Global Manager. Houston, T.X.: Gulf Publishing Co.

Harrison, D. A., \& Sin, H. (2005). What is diversity and how should it be measured. In A. M. Konrad, P. Prasad, \& J. K. Pringle (Eds.), Handbook of Workplace Diversity (pp. 191216). London, England: Sage.

Hartmann, N. N., \& Rutherford, B. N. (2015). Psychological contract breach's antecedents and outcomes in salespeople: The roles of psychological climate, job attitudes, and turnover intention. Industrial Marketing Management, 51, 158-170.

Harzing, A. W. (1995). The persistent myth of high expatriate failure rates. International Journal of Human Resource Management, 6(2), 457-474.

Harzing, A. W. (2001). Of bears, bumble-bees, and spiders: The role of expatriates in controlling foreign subsidiaries. Journal of World Business, 36(4), 366-379. 
Harzing, A. W., Brown, M., Köster, K., \& Zhao, S. (2012). Response style differences in cross-national research. Management International Review, 52(3), 341-363.

Harzing, A. W., \& Christensen, C. (2004). Expatriate failure: time to abandon the concept?. Career Development International, 9(7), 616-626.

Harzing, A. W., Pudelko, M., \& Sebastian Reiche, B. (2016). The bridging role of expatriates and inpatriates in knowledge transfer in multinational corporations. Human Resource Management, 55(4), 679-695.

Heberlein, T. A., \& Baumgartner, R. (1978). Factors affecting response rates to mailed questionnaires: A quantitative analysis of the published literature. American Sociological Review, 43(4), 447-462.

Hechanova, R., Beehr, T. A., \& Christiansen, N. D. (2003). Antecedents and consequences of employees' adjustment to overseas assignment: a meta- analytic review. Applied Psychology, 52(2), 213-236.

Hekman, D. R., Bigley, G. A., Steensma, H. K., \& Hereford, J. F. (2009). Combined effects of organizational and professional identification on the reciprocity dynamic for professional employees. Academy of Management Journal, 52(3), 506-526.

Hendrix, W. H., Robbins, T., Miller, J., \& Summers, T. P. (1998). Effects of procedural and distributive justice on factors predictive of turnover. Journal of Social Behavior and Personality, 13(4), 611-632.

Herriot, P. (1992). The Career Management Challenge: Balancing Individual and Organisational Needs. London, England: Sage.

Herriot, P. (1995). Psychological contracts. In N. Nicholson (Ed.), Encyclopaedic Dictionary of Organisational Behaviour. Oxford, England: Basil Blackwell.

Herriot, P., Manning, W. E., \& Kidd, J. M. (1997). The content of the psychological contract. British Journal of Management, 8(2), 151-162.

Hertel, G., Geister, S., \& Konradt, U. (2005). Managing virtual teams: A review of current empirical research. Human Resource Management Review, 15(1), 69-95.

Herzberg, F. (2005). Motivation-hygiene theory. In J. B. Miner (Ed.), Organizational Behavior I: Essential Theories of Motivation and Leadership (pp. 61-74). New York, N.Y. : M. E. Sharpe.

Hess, N., \& Jepsen, D. M. (2009). Career stage and generational differences in psychological contracts. Career Development International, 14(3), 261-283. 
Hewstone, M. , Stroebe, W., Codol, J. P., \& Stephenson, G. (1988). Introduction to Social Psychology: A European Perspective. Oxford, England: Basil Blackwell.

Hiltrop, J. M. (1996). Managing the changing psychological contract. Employee Relations, 18(1), 36-49.

Hippler, T. (2009). Why do they go? Empirical evidence of employees' motives for seeking or accepting relocation. The International Journal of Human Resource Management, 20(6), 1381-1401.

Ho, Z. J. Y. (2012). What makes hotel expatriates remain in their overseas assignments: A grounded theory study. The Qualitative Report, 17(26), 1-22.

Hofstede, G. (1984). Cultural dimensions in management and planning. Asia Pacific Journal of Management, 1(2), 81-99.

Holmes, W., \& Piker, F. K. (1980). Expatriate failure: Prevention rather than cure. Personnel Management, 12, 30-32.

Hom, P. W., Griffeth, R. W., \& Sellaro, C. L. (1984). The validity of Mobley's (1977) model of employee turnover. Organizational Behavior and Human Performance, 34(2), 141-174.

Homans, G. C. (1958). Social behavior as exchange. American Journal of Sociology, 63(6), 597-606.

Homans, G. C. (1961). Social Behavior: Its Elementary Forms. New York, N.Y.: Harcourt, Brace \& World.

Hrebiniak, L. G., \& Alutto, J. A. (1972). Personal and role-related factors in the development of organizational commitment. Administrative Science Quarterly, 17(4), 555-573.

Hulin, C. L. (1968). Effects of changes in job-satisfaction levels on employee turnover. Journal of Applied Psychology, 52(2), 122-126.

Inkson, K., Arthur, M. B., Pringle, J., \& Barry, S. (1997). Expatriate assignment versus overseas experience: Contrasting models of international human resource development. Journal of World Business, 32(4), 351-368.

Jafri, H. (2014). Influence of personality on perception of psychological contract breach. Psychological Thought, 7(2), 168-178.

Janelli, R. L., \& Yim, D. (1993). Making capitalism: The social and cultural construction of a South Korean conglomerate. Stanford, CA: Stanford University Press. 
Johanson, J., \& Vahlne, J. E. (1977). The internationalization process of the firm: A model of knowledge development and increasing foreign market commitments. Journal of International Business Studies, 8(1), 23-32.

Johnson, J. P., Lenartowicz, T., \& Apud, S. (2006). Cross-cultural competence in international business: Toward a definition and a model. Journal of International Business Studies, 37(4), 525-543.

Jokinen, T., Brewster, C., \& Suutari, V. (2008). Career capital during international work experiences: Contrasting self-initiated expatriate experiences and assigned expatriation. The International Journal of Human Resource Management, 19(6), 979-998.

Jones, D. C., \& Vaughan, K. (1990). Close friendships among senior adults. Psychology and Aging, 5(3), 451-457.

José Chambel, M., \& Sobral, F. (2011). Training is an investment with return in temporary workers: A social exchange perspective. Career Development International, 16(2), 161-177.

Joshua-Gojer, A. E. (2012). Cross-cultural training and success versus failure of expatriates. Learning and Performance Quarterly, 1(2), 47-62.

Kahler, T. (1975). Drivers: The key to the process of scripts. Transactional Analysis Journal, 5(3), 280-284.

Kanfer, R. (1990). Motivation theory and industrial and organizational psychology. In. M. D. Dunnette, \& L. Hough (Eds.), Handbook of Industrial and Organizational Psychology (pp. 75-130). Palo Alto, C.A.: Consulting Psychologists Press.

Kanter, R. M. (1968). Commitment and social organization: A study of commitment mechanisms in utopian communities. American Sociological Review, 33(4), 499-517.

Kelley, H. H., \& Thibaut, J. W. (1978). Interpersonal Relations: A Theory of Interdependence. New York, N.Y.: Wiley.

Kesen, M. (2016). Linking organizational identification with individual creativity: Organizational citizenship behavior as a mediator. Journal of Yaşar University, 11(41), $56-66$.

Kessler, I., \& Undy, R. (1996). The New Employment Relationship: Examining the Psychological Contract. London, England: Institute of Personnel and Development.

Kickul, J., \& Lester, S. W. (2001). Broken promises: Equity sensitivity as a moderator between psychological contract breach and employee attitudes and behavior. Journal of Business and Psychology, 16(2), 191-217. 
Kickul, J., Lester, S. W., \& Belgio, E. (2004). Attitudinal and behavioral outcomes of psychological contract breach a cross cultural comparison of the United States and Hong Kong Chinese. International Journal of Cross Cultural Management, 4(2), 229-252.

Kickul, J., Lester, S. W., \& Finkl, J. (2002). Promise breaking during radical organizational change: do justice interventions make a difference?. Journal of Organizational Behavior, 23(4), 469-488.

Kim, K., \& Slocum, J. W. (2008). Individual differences and expatriate assignment effectiveness: The case of U.S.-based Korean expatriates. Journal of World Business, 43(1), 109-126.

Kim, K., Halliday, C. S., Zhao, Y., Wang, C., \& Von Glinow, M. A. (2018). Rewarding self- initiated expatriates: A skills- based approach. Thunderbird International Business Review, 60(1), 89-104.

Kim, K., Kirkman, B., Chen, G. (2008). Cultural intelligence and international assignment effectiveness: A conceptual model and preliminary findings. In S. Ang, \& L. Van Dyne (Eds.), Handbook of Cultural Intelligence: Theory Measurement, and applications (pp. 71-90). Armonk, N.Y.: M. E. Sharpe.

Kim, K., \& Von Glinow, M. A. (2017a). Contextual determinants in disclosing one's stigmatized identity during expatriation: The case of lesbian and gay self-initiated expatriates. Journal of Global Mobility, 5(3), 317-338.

Kim, K., \& Von Glinow, M. A. (2017b). Managing non-traditional human capital in international assignments: A qualitative analysis of the talent and innovation gaps. In S. K. Kundu, \& S. Munjal (Eds.), Human Capital and Innovation (pp. 91-129). London, England: Palgrave Macmillan.

Kirkman, B. L., Lowe, K. B., \& Gibson, C. B. (2006). A quarter century of culture's consequences: A review of empirical research incorporating Hofstede's cultural values framework. Journal of International Business Studies, 37(3), 285-320.

Knight, G. (1996). Born global. Wiley International Encyclopedia of Marketing.

Ko, H. C., \& Yang, M. L. (2011). The effects of cross-cultural training on expatriate assignments. Intercultural Communication Studies, 20(1), 158-174.

Kogut, B., \& Singh, H. (1988). The effect of national culture on the choice of entry mode. Journal of International Business Studies, 19(3), 411-432.

Kollock, P. (1994). The emergence of exchange structures: An experimental study of uncertainty, commitment, and trust. American Journal of sociology, 100(2), 313-345. 
Konopaske, R., \& Werner, S. (2002). Equity in non-North American contexts: Adapting equity theory to the new global business environment. Human Resource Management Review, 12(3), 405-418.

Kotter, J. P. (1973). The psychological contract: Managing the joining-up process. California Management Review, 15(3), 91-99.

KPMG. (2016). Global Assignment Policies and Practices Survey. Retrieved December 15,2017 , from https://www.google.com/url?sa=t\&rct=j\&q=\&esrc=s\&source=web\&cd=1\&ved=0ahUKE wiwpY-h4MbZAhVl6IMKHV-

ODB4QFggnMAA\&url=https $\% 3 \mathrm{~A} \% 2 \mathrm{~F} \% 2 \mathrm{Fassets} . \mathrm{kpmg}$.com $\% 2 \mathrm{Fcontent} \% 2 \mathrm{Fdam} \% 2 \mathrm{Fk}$ pmg\%2Fxx\%2Fpdf\%2F2016\%2F10\%2Fglobal-assignment-policies-and-practicessurvey-2016.pdf\&usg=AOvVaw0vaPYShHrlfMBHW2X_QmNW

Kraimer, M. L., \& Wayne, S. J. (2004). An examination of perceived organizational support as a multidimensional construct in the context of an expatriate assignment. Journal of Management, 30(2), 209-237.

Lam, T., Lo, A., \& Chan, J. (2002). New employees' turnover intentions and organizational commitment in the Hong Kong hotel industry. Journal of Hospitality \& Tourism Research, 26(3), 217-234.

Lambe, C. J., Wittmann, C. M., \& Spekman, R. E. (2001). Social exchange theory and research on business-to-business relational exchange. Journal of Business-to-Business Marketing, 8(3), 1-36.

Lambert, E. G., Hogan, N. L., \& Barton, S. M. (2001). The impact of job satisfaction on turnover intent: A test of a structural measurement model using a national sample of workers. The Social Science Journal, 38(2), 233-250.

Lavelle, J. J., Rupp, D. E., \& Brockner, J. (2007). Taking a multifoci approach to the study of justice, social exchange, and citizenship behavior: The target similarity model. Journal of management, 33(6), 841-866.

Lawler, E. J., \& Yoon, J. (1996). Commitment in exchange relations: Test of a theory of relational cohesion. American Sociological Review, 61(1), 89-108.

Lazarova, M., \& Caligiuri, P. (2001). Retaining repatriates: The role of organizational support practices. Journal of World business, 36(4), 389-401.

Lester, S. W., Turnley, W. H., Bloodgood, J. M., \& Bolino, M. C. (2002). Not seeing eye to eye: Differences in supervisor and subordinate perceptions of and attributions for psychological contract breach. Journal of Organizational Behavior, 23(1), 39-56. 
Leung, K., Bhagat, R. S., Buchan, N. R., Erez, M., \& Gibson, C. B. (2005). Culture and international business: Recent advances and their implications for future research. Journal of International Business Studies, 36(4), 357-378.

Levinson, H., Price, C. R., Munden, K. J., Mandl, H. J., \& Solley, C. M. (1962). Men, Management, and Mental Health. Cambridge, M.A.: Harvard University Press.

Lévy-Garboua, L., Montmarquette, C., \& Simonnet, V. (2007). Job satisfaction and quits. Labour Economics, 14(2), 251-268.

Li, J. J., Wong, I. A., \& Kim, W. G. (2016). Effects of psychological contract breach on attitudes and performance: The moderating role of competitive climate. International Journal of Hospitality Management, 55, 1-10.

Liao- Troth, M. A. (2001). Attitude differences between paid workers and volunteers. Nonprofit Management and Leadership, 11(4), 423-442.

Linde, B. (2015). The Value of Wellness in the Workplace: A Perspective of the Employee-Organisation Relationship in the South African Labour Market. London, England: Springer.

Liu, R. R., \& McClure, P. (2001). Recognizing cross-cultural differences in consumer complaint behavior and intentions: an empirical examination. Journal of Consumer Marketing, 18(1), 54-75.

Lo, S., \& Aryee, S. (2003). Psychological contract breach in a Chinese context: An integrative approach. Journal of Management Studies, 40(4), 1005-1020.

Locke, E. A. (1976). The nature and causes of job satisfaction. In M. D. Dunnette (Ed.), Handbook of Industrial and Organizational Psychology (pp. 1297-1343). Chicago, I.L.: Rand McNally.

Locke, E. A. (1984). Job satisfaction. In M. Gruneberg, \& T. Wall (Eds.), Social Psychology and Organizational Behaviour (pp. 93-117). Chichester, England: Wiley.

Locke, E. A., \& Latham, G. P. (1990). A Theory of Goal Setting \& Task Performance. Englewood Cliffs, N.J.: Prentice-Hall.

Loewenstein, G. F., Thompson, L., \& Bazerman, M. H. (1989). Social utility and decision making in interpersonal contexts. Journal of Personality and Social Psychology, 57(3), 426-441.

Lub, X., Bal, P. M., Blomme, R. J., \& Schalk, R. (2016). One job, one deal... or not: Do generations respond differently to psychological contract fulfillment?. The International Journal of Human Resource Management, 27(6), 653-680. 
Lub, X., Nije Bijvank, M., Matthijs Bal, P., Blomme, R., \& Schalk, R. (2012). Different or alike? Exploring the psychological contract and commitment of different generations of hospitality workers. International Journal of Contemporary Hospitality Management, 24(4), 553-573.

Luthans, F. (1989). Organizational Behavior. New York, N.Y.: McGraw-Hill.

Luthans, F., Avolio, B. J., Avey, J. B., \& Norman, S. M. (2007). Positive psychological capital: Measurement and relationship with performance and satisfaction. Personnel Psychology, 60(3), 541-572.

Luthans, F., Avolio, B. J., Walumbwa, F. O., \& Li, W. (2005). The psychological capital of Chinese workers: Exploring the relationship with performance. Management and Organization Review, 1(2), 249-271.

Malhotra, A., Majchrzak, A., \& Rosen, B. (2007). Leading virtual teams. The Academy of Management Perspectives, 21(1), 60-70.

March, J. G., \& Simon, H. A. (1958). Organizations. New York, N.Y.: Wiley.

Marks, A. (2001). Developing a multiple foci conceptualization of the psychological contract. Employee Relations, 23(5), 454-469.

Maslow, A. H. (1946). A theory of human motivation. Psychological Review, 50(4), 370396.

Mathieu, J. E., Tannenbaum, S. I., \& Salas, E. (1992). Influences of individual and situational characteristics on measures of training effectiveness. Academy of Management Journal, 35(4), 828-847.

Mathieu, J. E., \& Zajac, D. M. (1990). A review and meta-analysis of the antecedents, correlates, and consequences of organizational commitment. Psychological Bulletin, 108(2), 171-194.

Maude, B. (2011). Managing Cross-Cultural Communication: Principles and Practice. New York, N.Y.: Palgrave Macmillan.

Maurer, R. (2013). International Assignments Expected to Increase in 2013. Retrieved December 15, 2017, from https://www.shrm.org/resourcesandtools/hr-topics/global$\mathrm{hr} /$ pages/international-assignments-increase-2013.aspx

Mayerhofer, H., Hartmann, L. C., Michelitsch-Riedl, G., \& Kollinger, I. (2004). Flexpatriate assignments: A neglected issue in global staffing. The International Journal of Human Resource Management, 15(8), 1371-1389. 
Mayrhofer, W., Sparrow, P., \& Zimmermann, A. (2008). Modern forms of international working. In M. Dickmann, C. Brewster, \& P. R. Sparrow (Eds.), International Human Resource Management: Contemporary Issues in Europe (pp. 219-239). London, England: Routledge.

Maznevski, M. L., \& Chudoba, K. M. (2000). Bridging space over time: Global virtual team dynamics and effectiveness. Organization Science, 11(5), 473-492.

Maznevski, M., Davidson, S. C., \& Jonsen, K. (2006). Global virtual team dynamics and effectiveness. In G. K. Stahl, \& I. Björkman (Eds.), Handbook of Research in International Human Resource Management (pp. 364-384). Northampton, M.A.: Edward Elgar.

McClelland, D. C. (1989). Motivational factors in health and disease. American Psychologist, 44(4), 675-683.

McCulloch, B. J. (1990). The relationship of intergenerational reciprocity of aid to the morale of older parents: Equity and exchange theory comparisons. Journal of Gerontology, 45(4), S150-S155.

McGinley, J. (2008). Expatriate adjustment within a social context: Examination of a sample in Russia. Journal of Social, Evolutionary, and Cultural Psychology, 2(2), 56-68.

McGregor, D. (1957). The human side of enterprise. The Management Review, 46(11), 22-28.

McLean Parks, J., Kidder, D. L., \& Gallagher, D. G. (1998). Fitting square pegs into round holes: Mapping the domain of contingent work arrangements onto the psychological contract. Journal of Organizational Behavior, 19(S1), 697-730.

McNulty, Y. M. (2013). Are self-initiated expatriates born or made? Exploring the relationship between SIE orientation and individual ROI. In V. Vaiman, \& A. Haslberger (Eds.), Managing Talent of Self-Enitiated expatriates: A Neglected Source of Global Talent (pp. 30-58). London, England: Palgrave Macmillan.

McNulty, Y. M. (2014). Re-Focusing Expatriate Employment Relationships Using Psychological Contracts. Retrieved December 15, 2017, from https://www.google.com/url?sa=t\&rct=j\&q=\&esrc=s\&source=web\&cd=1\&ved=0ahUKE wib0ZeUxcbZAhURxVkKHU18AR8QFggnMAA\&url=http\%3A\%2F\%2Fexpatresearch. com\%2Findex.php \%2Fdownload_file\%2Fview\%2F152\%2F179\%2F\&usg=AOvVaw1wf Q_0yoFleGguhmx4h9aX

McNulty, Y. M., \& Selmer, J. (2017). Research Handbook of Expatriates. Cheltenham, England: Edward Elgar. 
Mendenhall, M. E. (2005). Mergers and Acquisitions: Managing Culture and Human Resources. Stanford, C.A.: Stanford University Press.

Mendenhall, M. E., \& Oddou, G. (1985). The dimensions of expatriate acculturation: A review. Academy of Management Review, 10(1), 39-47.

Mercer. (2014). Short-Term Assignments and Commuters. Retrieved December 15, 2017 , from

https://www.google.com/url?sa=t\&rct=j\&q=\&esrc=s\&source=web\&cd=2\&ved=0ahUKE wib0v-

54sbZAhVp6IMKHbfbAUAQFggtMAE\&url=https\%3A\%2F\%2Fwww.imercer.com\%2F uploads \%2FGM\%2Fwebcasts\%2F2014\%2FShort-term-Assignments-Commuters-

EMEA-Mercer-Webcast-1403.pdf\&usg=AOvVaw0AmqCCIkiuwIAKHr6VDSa6

Mercer. (2015). Mobility and Diversity: Underused Resources to Mitigate Talent Shortages. Retrieved December 15, 2017, from

www.google.co.kr/url?sa=t\&rct=j\&q=\&esrc=s\&source=web\&cd=1\&ved=0ahUKEwiw5 Z_CyobRAhUHpJQKHZ-

PAj0QFggYMAA\&url=https $\% 3 \mathrm{~A} \% 2 \mathrm{~F} \% 2 \mathrm{Fwww}$.imercer.com $\% 2$ Fuploads $\% 2$ FEurope $\%$ 2FHTML\%2Flanding_pages\%2Fexpat-conference-post-

event $\% 2$ Fpresentations $\% 2 F M o b i l i t y-a n d-$

Diversity.pdf\&usg=AFQjCNEBS9GGXIyzQX8Pz61R6zDP_VnRbA\&bvm=bv.1420598 68, d.dGo\&cad=rja

Messick, D. M., \& Sentis, K. P. (1979). Fairness and preference. Journal of Experimental Social Psychology, 15(4), 418-434.

Meyer, J. P., Paunonen, S. V., Gellatly, I. R., Goffin, R. D., \& Jackson, D. N. (1989). Organizational commitment and job performance: It's the nature of the commitment that counts. Journal of applied Psychology, 74(1), 152-156.

Meyskens, M., Von Glinow, M. A., Werther, Jr, W. B., \& Clarke, L. (2009). The paradox of international talent: Alternative forms of international assignments. The International Journal of Human Resource Management, 20(6), 1439-1450.

Millward, L. J., \& Brewerton, P. M. (1999). Contractors and their psychological contracts. British Journal of Management, 10(3), 253-274.

Mobley, W. H. (1977). Intermediate linkages in the relationship between job satisfaction and employee turnover. Journal of Applied Psychology, 62(2), 237-240.

Mobley, W. H., Griffeth, R. W., Hand, H. H., \& Meglino, B. M. (1979). Review and conceptual analysis of the employee turnover process. Psychological Bulletin, 86(3), 493522. 
Montes, S. D., \& Zweig, D. (2009). Do promises matter? An exploration of the role of promises in psychological contract breach. Journal of Applied Psychology, 94(5), 12431260.

Morf, M., Arnold, A., \& Staffelbach, B. (2014). The double psychological contracts of temporary agency workers. Employee Relations, 36(6), 708-726.

Morrison, E. W., \& Robinson, S. L. (1997). When employees feel betrayed: A model of how psychological contract violation develops. Academy of Management Review, 22(1), 226-256.

Mowday, R. T., Porter, L. W., \& Steers, R. M. (1982). Employee-Organization Linkages: The Psychology of Employee Commitment, Absenteeism, and Turnover. New York, N.Y.: Academic Press.

Naumann, E. (1992). A conceptual model of expatriate turnover. Journal of International Business Studies, 23(3), 499-531.

Nelson, D. L., \& Quick, J. C. (2006). Organizational Behavior: Foundations, Realities \& Challenges. Mason, O.H.: South-Western/Thompson.

Ng, T. W., \& Feldman, D. C. (2009). Age, work experience, and the psychological contract. Journal of Organizational Behavior, 30(8), 1053-1075.

Ng, T. W., \& Sorensen, K. L. (2008). Toward a further understanding of the relationships between perceptions of support and work attitudes: A meta-analysis. Group \& Organization Management, 33(3), 243-268.

Nicholson, N., \& Imaizumi, A. (1993). The adjustment of Japanese expatriates to living and working in Britain. British Journal of Management, 4(2), 119-134.

Niehoff, B. P., Moorman, R. H., Blakely, G., \& Fuller, J. (2001). The influence of empowerment and job enrichment on employee loyalty in a downsizing environment. Group \& Organization Management, 26(1), 93-113.

Nikolaou, I., Tomprou, M., \& Vakola, M. (2007). Individuals' inducements and the role of personality: Implications for psychological contracts. Journal of Managerial Psychology, 22(7), 649-663.

Oviatt, B. M., \& McDougall, P. P. (1994). Toward a theory of international new ventures. Journal of International Business Studies, 25(1), 45-64.

Parente, R., Baack, D., \& Almeida, V. (2008). Psychic distance and directional equivalence: A theoretical framework. In S. Tallman (Ed.), A New Generation in International Strategic Management (pp. 308-325). Cheltenham, England: Edward Elgar. 
Parker, B., \& McEvoy, G. M. (1993). Initial examination of a model of intercultural adjustment. International Journal of Intercultural Relations, 17(3), 355-379.

Parks, J. M., \& Kidder, D. L. (1994). Till death us do part: Changing work relationships in the 1990s. Journal of Organizational Behavior, 15(1), 111-136.

Pate, J. (2006). The changing contours of the psychological contract: Unpacking context and circumstances of breach. Journal of European Industrial Training, 30(1), 32-47.

Pate, J., \& Malone, C. (2000). Post-“psychological contract" violation: The durability and transferability of employee perceptions: The case of TimTec. Journal of European Industrial Training, 24(2/3/4), 158-166.

Pate, J., Martin, G., \& McGoldrick, J. (2003). The impact of psychological contract violation on employee attitudes and behaviour. Employee Relations, 25(6), 557-573.

Pate, J., \& Scullion, H. (2009). The changing nature of the traditional expatriate psychological contract. Employee Relations, 32(1), 56-73.

Pate, J., \& Scullion, H. (2016). The flexpatriate psychological contract: A literature review and future research agenda. The International Journal of Human Resource Management, 1-24.

Paul, R. J., Niehoff, B. P., \& Turnley, W. H. (2000). Empowerment, expectations, and the psychological contract: Managing the dilemmas and gaining the advantages. The Journal of Socio-Economics, 29(5), 471-485.

Peel, S., \& Inkson, K. (2004). Contracting and careers: Choosing between self and organizational employment. Career Development International, 9(6), 542-558.

Peltokorpi, V. (2008). Cross-cultural adjustment of expatriates in Japan. The International Journal of Human Resource Management, 19(9), 1588-1606.

Peng, K. Z., Wong, C. S., \& Song, J. L. (2016). How do Chinese employees react to psychological contract violation?. Journal of World Business, 51(5), 815-825.

Peng, M. W. (2013). Global Business. Mason, O.H.: South-Western Cengage Learning.

Perera, H. K., Chew, Y. T., \& Nielsen, I. (2016a). A qualitative study of expatriates' perceptions of and process of responses to psychological contract breach. The International Journal of Human Resource Management, 13, 1-31.

Perera, H. K., Chew, Y. T., \& Nielsen, I. (2016b). A psychological contract perspective of expatriate failure. Human Resource Management, 56(3), 479-499. 
Perkins, S. J., \& Daste, R. (2007). Pluralistic tensions in expatriating managers. Journal of European Industrial Training, 31(7), 550-569.

Perugini, M., Gallucci, M., Presaghi, F., \& Ercolani, A. P. (2003). The personal norm of reciprocity. European Journal of Personality, 17(4), 251-283.

Podsakoff, N. P., LePine, J. A., \& LePine, M. A. (2007). Differential challenge stressorhindrance stressor relationships with job attitudes, turnover intentions, turnover, and withdrawal behavior: A meta-analysis. Journal of Applied Psychology, 92(2), 438-454.

Podsakoff, P. M., MacKenzie, S. B., Lee, J. Y., \& Podsakoff, N. P. (2003). Common method biases in behavioral research: A critical review of the literature and recommended remedies. Journal of Applied Psychology, 88(5), 879-903.

Porter, L. W., \& Lawler, E. E. (1968). Managerial Attitudes and Performance. Homewood, I.L.: Irwin-Dorsey.

Porter, L. W., \& Steers, R. M. (1973). Organizational, work, and personal factors in employee turnover and absenteeism. Psychological Bulletin, 80(2), 151-176.

Puck, J. F., Kittler, M. G., \& Wright, C. (2008). Does it really work? Re-assessing the impact of pre-departure cross-cultural training on expatriate adjustment. The International Journal of Human Resource Management, 19(12), 2182-2197.

PWC. (2015). Moving People With Purpose: Modern Mobility Survey. Retrieved December 15, 2017, from http://download.pwc.com/ie/pubs/2015-pwc-ireland-gemmoving-people-with-purpose.pdf

Raja, U., Johns, G., \& Ntalianis, F. (2004). The impact of personality on psychological contracts. Academy of Management Journal, 47(3), 350-367.

Reiche, B. S. (2009). To quit or not to quit: Organizational determinants of voluntary turnover in MNC subsidiaries in Singapore. The International Journal of Human Resource Management, 20(6), 1362-1380.

Reiche, B. S., Harzing, A. W., \& Kraimer, M. L. (2009). The role of international assignees' social capital in creating inter-unit intellectual capital: A cross-level model. Journal of International Business Studies, 40(3), 509-526.

Reiche, R. (2014). Expats in Emerging Markets: Revising Previous Trends?. Retrieved December 15, 2017, from http://blog.iese.edu/expatriatus/2014/07/16/expats-inemerging-markets-revision-of-old-arguments/

Reimann, M., \& Guzy, J. (2017). Psychological contract breach and employee health: The relevance of unmet obligations for mental and physical health. Revista de Psicología del Trabajo y de las Organizaciones, 33(1), 1-11. 
Rennie, M. W. (1993). Global competitiveness: Born global. The McKinsey Quarterly, 4, 45-53.

Restubog, S. L., Bordia, P., \& Bordia, S. (2009). The interactive effects of procedural justice and equity sensitivity in predicting responses to psychological contract breach: An interactionist perspective. Journal of Business and Psychology, 24(2), 165-178.

Restubog, S. L., Bordia, P., \& Tang, R. L. (2006). Effects of psychological contract breach on performance of IT employees: The mediating role of affective commitment. Journal of Occupational and Organizational Psychology, 79(2), 299-306.

Reynolds, C. (1997). Expatriate compensation in historical perspective. Journal of World Business, 32(2), 118-132.

Rhoades, L., \& Eisenberger, R. (2002). Perceived organizational support: A review of the literature. Journal of Applied Psychology, 87(4), 698-714.

Richard, O. C., McMillan-Capehart, A., Bhuian, S. N., \& Taylor, E. C. (2009). Antecedents and consequences of psychological contracts: Does organizational culture really matter?. Journal of Business Research, 62(8), 818-825.

Riusala, K., \& Suutari, V. (2004). International knowledge transfers through expatriates. Thunderbird International Business Review, 46(6), 743-770.

Robbins, S. P., Millett, B., \& Waters-Marsh, T. (2004). Organisational Behaviour: Leading and Managing in Australia and New Zealand. Frenchs Forest, Australia: Pearson Education.

Robinson, S. L. (1996). Trust and breach of the psychological contract. Administrative Science Quarterly, 4(1), 574-599.

Robinson, S. L., Kraatz, M. S., \& Rousseau, D. M. (1994). Changing obligations and the psychological contract: A longitudinal study. Academy of Management Journal, 37(1), 137-152.

Robinson, S. L., \& Morrison, E. W. (1995). Psychological contracts and OCB: The effect of unfulfilled obligations on civic virtue behavior. Journal of Organizational Behavior, 16(3), 289-298.

Robinson, S. L., \& Morrison, E. W. (2000). The development of psychological contract breach and violation: A longitudinal study. Journal of Organizational Behavior, 21(5), 525-546.

Robinson, S. L., \& Rousseau, D. M. (1994). Violating the psychological contract: Not the exception but the norm. Journal of Organizational Behavior, 15(3), 245-259. 
Roehl, W. S., \& Swerdlow, S. (1999). Training and its impact on organizational commitment among lodging employees. Journal of Hospitality \& Tourism Research, 23(2), 176-194.

Rossi, P. H., Wright, J. D., \& Anderson, A. B. (2013). Handbook of Survey Research. San Diego, C.A.: Academic Press.

Rousseau, D. M. (1989). Psychological and implied contracts in organizations. Employee Responsibilities and Rights Journal, 2(2), 121-139.

Rousseau, D. M. (1990). New hire perceptions of their own and their employer's obligations: A study of psychological contracts. Journal of Organizational Behavior, 11(5), 389-400.

Rousseau, D. M. (1995). Psychological Contracts in Organizations: Understanding Written and Unwritten Agreements. Thousand Oaks, C.A.: Sage.

Rousseau, D. M. (2001). Schema, promise and mutuality: The building blocks of the psychological contract. Journal of Occupational and Organizational Psychology, 74(4), 511-541.

Rousseau, D. M., \& Greller, M. M. (1994). Human resource practices: Administrative contract makers. Human Resource Management, 33(3), 385-401.

Rousseau, D. M., \& McLean Parks, J. (1993). The contracts of individuals and organizations. In L. L. Cummings, \& B. M. Staw (Eds.), Research in Organizational Behavior, (pp. 1-43). Greenwich, C.T.: JAI Press.

Rousseau, D. M., \& Schalk, R. (2000). Psychological Contracts in Employment: CrossNational Perspectives. Thousand Oaks, C.A.: Sage.

Rousseau, D. M., \& Tijoriwala, S. A. (1998). Assessing psychological contracts: Issues, alternatives and measures. Journal of Organizational Behavior, 19(7), 679-695.

Rousseau, D. M., \& Wade-Benzoni, K. A. (1995). Changing individual-organization attachments: A two-way street. In A. Howard (Ed.), The Changing Nature of Work (pp. 290-322). San Francisco, C.A.: Jossey-Bass.

Rynes, S. L., Colbert, A. E., \& Brown, K. G. (2002). HR professionals' beliefs about effective human resource practices: Correspondence between research and practice. Human Resource Management, 41(2), 149-174.

Saari, L. M., \& Judge, T. A. (2004). Employee attitudes and job satisfaction. Human Resource Management, 43(4), 395-407. 
Sarstedt, M., Bengart, P., Shaltoni, A. M., \& Lehmann, S. (2017). The use of sampling methods in advertising research: A gap between theory and practice. International Journal of Advertising, 1-14.

Schalk, R. (2004). Changes in the employment relationship across time. In J. A. M. Coyle-Shapiro, L. M. Shore, M. S. Taylor, \& L. E. Tetrick (Eds.), The Employment Relationship: Examining Psychological and Contextual Perspectives (pp. 284-311). Oxford, N.Y.: Oxford University Press.

Schein, E. H. (1978). Career Dynamics: Matching Individual and Organizational Needs. Reading, M.A.: Addison-Wesley.

Schein, E. H. (1988). Organizational Psychology. Englewood Cliffs, N.J.: Prentice-Hall.

Schein, E. H. (1996). Career anchors revisited: Implications for career development in the 21 st century. The Academy of Management Executive, 10(4), 80-88.

Schuler, R. S., Budhwar, P. S., \& Florkowski, G. W. (2002). International human resource management: Review and critique. International Journal of Management Reviews, 4(1), 41-70.

Schuler, R. S., Jackson, S. E., \& Tarique, I. (2011). Global talent management and global talent challenges: Strategic opportunities for IHRM. Journal of World Business, 46(4), 506-516.

Schuler, R. S., Tarique, I., \& Jackson, S. E. (2004). Managing human resources in crossborder alliances. In C. L. Cooper, \& S. Finkelstein (Eds.), Advances in Mergers and Acquisitions (pp. 103-129). Amsterdam, Netherlands: JAI Press.

Scullion, H., \& Collings, D. G. (2006). Global Staffing. London, England: Routledge.

Searle, W., \& Ward, C. (1990). The prediction of psychological and sociocultural adjustment during cross-cultural transitions. International Journal of Intercultural Relations, 14(4), 449-464.

Seeck, H., \& Parzefall, M. R. (2010). From HRM to psychological contracting-the case of Finnish mobile content producing companies. The International Journal of Human Resource Management, 21(15), 2677-2693.

Selmer, J. (2001). The preference for predeparture or postarrival cross-cultural training: An exploratory approach. Journal of Managerial Psychology, 16(1), 50-58.

Selmer, J. (2002). Practice makes perfect? International experience and expatriate adjustment. Management International Review, 42(1), 71-87. 
Selmer, J. (2004). Psychological barriers to adjustment of Western business expatriates in China: Newcomers vs long stayers. The International Journal of Human Resource Management, 15(4-5), 794-813.

Selmer, J., \& Lauring, J. (2010). Self- initiated academic expatriates: Inherent demographics and reasons to expatriate. European Management Review, 7(3), 169-179.

Shaffer, M. A., \& Harrison, D. A. (1998). Expatriates' psychological withdrawal from international assignments: Work, nonwork, and family influences. Personnel Psychology, 51(1), 87-118.

Shaffer, M. A., Harrison, D. A., \& Gilley, K. M. (1999). Dimensions, determinants, and differences in the expatriate adjustment process. Journal of International Business Studies, 30(3), 557-581.

Shapiro, D. L., Von Glinow, M. A., \& Xiao, Z. (2007). Toward polycontextually sensitive research methods. Management and Organization Review, 3(1), 129-152.

Sharif, M. M., \& Scandura, T. A. (2014). Do perceptions of ethical conduct matter during organizational change? Ethical leadership and employee involvement. Journal of Business Ethics, 124(2), 185-196.

Shaw, J. D., Delery, J. E., Jenkins, G. D., \& Gupta, N. (1998). An organization-level analysis of voluntary and involuntary turnover. Academy of Management Journal, 41(5), 511-525.

Shay, J. P., \& Baack, S. (2006). An empirical investigation of the relationships between modes and degree of expatriate adjustment and multiple measures of performance. International Journal of Cross Cultural Management, 6(3), 275-294.

Sheldon, M. E. (1971). Investments and involvements as mechanisms producing commitment to the organization. Administrative Science Quarterly, 16(2), 143-150.

Shen, J., \& Edwards, V. (2004). Recruitment and selection in Chinese MNEs. The International Journal of Human Resource Management, 15(4-5), 814-835.

Shenkar, O. (2001). Cultural distance revisited: Towards a more rigorous conceptualization and measurement of cultural differences. Journal of International Business Studies, 32(3), 519-535.

Shin, J., Taylor, M. S., \& Seo, M. G. (2012). Resources for change: The relationships of organizational inducements and psychological resilience to employees' attitudes and behaviors toward organizational change. Academy of Management Journal, 55(3), 727748. 
Shore, L. M., \& Barksdale, K. (1998). Examining degree of balance and level of obligation in the employment relationship: A social exchange approach. Journal of Organizational Behavior, 19(1), 731-744.

Shore, L. M., \& Coyle- Shapiro, J. A. M. (2003). New developments in the employeeorganization relationship. Journal of Organizational Behavior, 24(5), 443-450.

Shore, L. M., \& Tetrick, L. E. (1994). The psychological contract as an explanatory framework in the employment relationship. Journal of Organizational Behavior, 1, 91109.

SHRM. (2016). Human Capital Benchmarking Report. Retrieved December 15, 2017, from https://www.google.com/url?sa=t\&rct=j\&q=\&esrc=s\&source=web\&cd=1\&ved=0ahUKE wj13LbqnsjZAhVFmlkKHUHAkIQFggnMAA\&url=https\%3A\%2F\%2Fwww.shrm.org\%2Fhr-today\%2Ftrends-andforecasting\%2Fresearch-and-surveys $\% 2$ FDocuments $\% 2$ F2016-Human-CapitalReport.pdf\&usg=AOvVaw3qKKiAz6ZdbmNiiqdIfJGT

Siemsen, E., Roth, A., \& Oliveira, P. (2010). Common method bias in regression models with linear, quadratic, and interaction effects. Organizational Research Methods, 13(3), 456-476.

Silverthorne, C. (2004). The impact of organizational culture and person-organization fit on organizational commitment and job satisfaction in Taiwan. Leadership \& Organization Development Journal, 25(7), 592-599.

Sims, R. R. (1994). Human resource management's role in clarifying the new psychological contract. Human Resource Management, 33(3), 373-382.

Skromme Granrose, C., \& Baccili, P. A. (2006). Do psychological contracts include boundaryless or protean careers?. Career Development International, 11(2), 163-182.

Smith, K. G., \& Hitt, M. A. (2005). Great Minds in Management: The Process of Theory Development. Oxford, England: Oxford University Press.

Smithson, J., \& Lewis, S. (2000). Is job insecurity changing the psychological contract?. Personnel Review, 29(6), 680-702.

Sorenson, O., \& Waguespack, D. M. (2006). Social structure and exchange: Selfconfirming dynamics in Hollywood. Administrative Science Quarterly, 51(4), 560-589.

Sousa, C. M., \& Bradley, F. (2006). Cultural distance and psychic distance: Two peas in a pod?. Journal of International Marketing, 14(1), 49-70. 
Sparrow, P. R. (1996). Transitions in the psychological contract: Some evidence from the banking sector. Human Resource Management Journal, 6(4), 75-92.

Sparrow, P. R., \& Cooper, C. L. (1998). New organizational forms: The strategic relevance of future psychological contract scenarios. Canadian Journal of Administrative Science, 15(4), 356-371.

Sparrow, P. R., \& Cooper, C. L. (2003). The New Employment Relationship. Oxford, England: Butterworth-Heinemann.

Stahl, G. K. (2001). Using assessment centers as tools for global leadership development: An exploratory study. In M. E. Mendenhall, T. M. Kühlmann, \& G. K. Stahl (Eds.), Developing Global Business Leaders: Policies, Processes, and Innovations (pp. 197-210). Westport, C.T.: Quorum.

Stahl, G. K., Björkman, I., Farndale, E., Morris, S.S., Paauwe, J., Stiles, P., Trevor, J., \& Wright, P. (2012). Six principles of effective global talent management. Sloan Management Review, 53(2), 25-42.

Stahl, G. K., Miller, E. L., \& Tung, R. L. (2002). Toward the boundaryless career: A closer look at the expatriate career concept and the perceived implications of an international assignment. Journal of World Business, 37(3), 216-227.

Starr, T. L., \& Currie, G. (2009). 'Out of sight but still in the picture': Short-term international assignments and the influential role of family. The International Journal of Human Resource Management, 20(6), 1421-1438.

Staw, B. M., \& Ross, J. (1985). Stability in the midst of change: A dispositional approach to job attitudes. Journal of Applied Psychology, 70(3), 469-480.

Steel, R. P., \& Ovalle, N. K. (1984). A review and meta-analysis of research on the relationship between behavioral intentions and employee turnover. Journal of Applied Psychology, 69(4), 673-686.

Steensma, H., Van Breukelen, W., \& Sturm, M. (2004). Studying employee turnover by splitting up the usual comparison group. Journal of Individual Employment Rights, 11(3), 211-227.

Steers, R. M., \& Porter, L. W. (1991). Work and motivation: Some concluding observations. In R. M. Steers, \& L. W. Porter (Eds.), Motivation and Work Behavior (pp. 573-582). New York, N.Y.: McGraw-Hill.

Steers, R. M., Mowday, R. T., \& Shapiro, D. L. (2004). Introduction to special topic forum: The future of work motivation theory. The Academy of Management Review, 29(3), 379-387. 
Steve Chi, S. C., \& Chen, S. C. (2007). Perceived psychological contract fulfillment and job attitudes among repatriates: An empirical study in Taiwan. International Journal of Manpower, 28(6), 474-488.

Strubler, D., Park, S. H., \& Agarwal, A. (2011). Revisiting Black, Mendenhall, and Oddou (1991)'s framework for international adjustment model: A prescriptive approach. Journal of International Business Research, 10(2), 103-120.

Suazo, M. M. (2009). The mediating role of psychological contract violation on the relations between psychological contract breach and work-related attitudes and behaviors. Journal of Managerial Psychology, 24(2), 136-160.

Sutton, G., \& Griffin, M. A. (2004). Integrating expectations, experiences, and psychological contract violations: A longitudinal study of new professionals. Journal of Occupational and Organizational Psychology, 77(4), 493-514.

Suutari, V., \& Brewster, C. (2000). Making their own way: International experience through self-initiated foreign assignments. Journal of World Business, 35(4), 417-436.

Suutari, V., Tornikoski, C., \& Mäkelä, L. (2012). Career decision making of global careerists. The International Journal of Human Resource Management, 23(16), 34553478.

Tahvanainen, M., Welch, D., \& Worm, V. (2005). Implications of short-term international assignments. European Management Journal, 23(6), 663-673.

Takeuchi, R., Yun, S., \& Tesluk, P. E. (2002). An examination of crossover and spillover effects of spousal and expatriate cross-cultural adjustment on expatriate outcomes. Journal of Applied Psychology, 87(4), 655-666.

Tallman, R. R., \& Bruning, N. S. (2008). Relating employees' psychological contracts to their personality. Journal of Managerial Psychology, 23(6), 688-712.

Tanure, B., Barcellos, E. P., \& Fleury, M. T. L. (2009). Psychic distance and the challenges of expatriation from Brazil. The International Journal of Human Resource Management, 20(5), 1039-1055.

Taylor, M. S., \& Tekleab, A. G. (2004). Taking stock of psychological contract research: Assessing progress, addressing troublesome issues, and setting research priorities. In J. A. M. Coyle-Shapiro, L. M. Shore, M. S., Taylor, \& L. E. Tetrick (Eds.), The Employment Relationship. Examining Psychological and Contextual Perspectives (pp. 253-283). Oxford, England: Oxford University Press.

Taylor, S., Napier, N. K., \& Mayrhofer, W. (2002). Women in global business: Introduction. International Journal of Human Resource Management, 13(5), 739-742. 
Tekleab, A. G., \& Taylor, M. S. (2003). Aren't there two parties in an employment relationship? Antecedents and consequences of organization-employee agreement on contract obligations and violations. Journal of Organizational Behavior, 24(5), 585-608.

Tekleab, A. G., Takeuchi, R., \& Taylor, M. S. (2005). Extending the chain of relationships among organizational justice, social exchange, and employee reactions: The role of contract violations. Academy of Management Journal, 48(1), 146-157.

Templer, K. J., Tay, C., \& Chandrasekar, N. A. (2006). Motivational cultural intelligence, realistic job preview, realistic living conditions preview, and cross-cultural adjustment. Group \& Organization Management, 31(1), 154-173.

Tett, R. P., \& Meyer, J. P. (1993). Job satisfaction, organizational commitment, turnover intention, and turnover: Path analyses based on meta- analytic findings. Personnel Psychology, 46(2), 259-293.

Tharenou, P. (2013). Self-initiated expatriates: An alternative to company-assigned expatriates?. Journal of Global Mobility, 1(3), 336-356.

Tharenou, P., \& Caulfield, N. (2010). Will I stay or will I go? Explaining repatriation by self-initiated expatriates. Academy of Management Journal, 53(5), 1009-1028.

The Economist. (2017). Adidas's High-Tech Factory Brings Production Back to Germany. Retrieved December 15, 2017, from https://www.economist.com/news/business/21714394-making-trainers-robots-and-3dprinters-adidass-high-tech-factory-brings-production-back

Thibaut, J. W., \& Kelley, H. H. (1959). The Social Psychology of Groups. Oxford, England: John Wiley \& Sons.

Thomas, D. C., Au, K., \& Ravlin, E. C. (2003). Cultural variation and the psychological contract. Journal of Organizational Behavior, 24(5), 451-471.

Thomas, D. C., Liao, Y., Aycan, Z., Cerdin, J. L., Pekerti, A. A., Ravlin, E. C., Stahl, G. K., Lazarova, M. B., Fock, H., Arli, D., Moeller, M., Okimoto, T., \& Van der Vijver, F. (2015). Cultural intelligence: A theory-based, short form measure. Journal of International Business Studies, 46(9), 1099-1118.

Toh, S. M., \& DeNisi, A. S. (2007). Host country nationals as socializing agents: A social identity approach. Journal of Organizational Behavior, 28(3), 281-301.

Torbiörn, I. (1988). Culture barriers as a social psychological construct: An empirical validation. In Y. Y. Kim, \& W. B. Gudykunst (Eds.), Cross-Cultural Adaptation: Current Approaches (pp. 168-190). Newbury Park, C.A.: Sage. 
Torbiörn, I. (1994). Operative and strategic use of expatriates in new organizations and market structures. International Studies of Management \& Organization, 24(3), 5-17.

Tornikoski, C. (2011). Fostering expatriate affective commitment: A total reward perspective. Cross-Cultural Management: An International Journal, 18(2), 214-235.

Tsang, E. W. (1999). The knowledge transfer and learning aspects of international HRM: An empirical study of Singapore MNCs. International Business Review, 8(5-6), 591-609.

Tugade, M. M., \& Fredrickson, B. L. (2004). Resilient individuals use positive emotions to bounce back from negative emotional experiences. Journal of Personality and Social Psychology, 86(2), 320-333.

Tung, R. L. (1981). Selection and training of personnel for overseas assignments. Columbia Journal of World Business, 16(1), 68-78.

Tung, R. L. (1988). The New Expatriates: Managing Human Resources Abroad. Cambridge, M.A.: Ballinger.

Tung, R. L. (1998). American expatriates abroad: From neophytes to cosmopolitans. Journal of World Business, 33(2), 125-144.

Tungli, Z., \& Peiperl, M. (2009). Expatriate practices in German, Japanese, U.K., and U.S. multinational companies: A comparative survey of changes. Human Resource Management, 48(1), 153-171.

Turnley, W. H., Bolino, M. C., Lester, S. W., \& Bloodgood, J. M. (2003). The impact of psychological contract fulfillment on the performance of in-role and organizational citizenship behaviors. Journal of Management, 29(2), 187-206.

Turnley, W. H., \& Feldman, D. C. (1998). Psychological contract violations during corporate restructuring. Human Resource Management, 37(1), 71-83.

Turnley, W. H., \& Feldman, D. C. (1999). The impact of psychological contract violations on exit, voice, loyalty, and neglect. Human Relations, 52(7), 895-922.

Turnley, W. H., \& Feldman, D. C. (2000). Re-examining the effects of psychological Note contract violations: Unmet expectations and job dissatisfaction as mediators. Journal of Organizational Behavior, 21(1), 25-42.

United Nations Conference on Trade and Development. (2016). World Investment Report 2016. Retrieved December 15, 2017, from https://www.google.com/url?sa=t\&rct=j\&q=\&esrc=s\&source=web\&cd=1\&ved=0ahUKE wi0joyU487ZAhUJjlkKHQ9VCUEQFggnMAA\&url=http\%3A\%2F\%2Functad.org\%2Fe n\%2FPublicationsLibrary\%2Fwir2016_en.pdf\&usg=AOvVaw1ppiwX34km1cnZ-yYXfo- 
Vance, C. M., Paik, Y., \& White, J. A. (2006). Tracking bias against the selection of female expatriates: Implications and opportunities for business education. Thunderbird International Business Review, 48(6), 823-842.

Van Der Vaart, L., Linde, B., \& Cockeran, M. (2013). The state of the psychological contract and employees' intention to leave: The mediating role of employee well-being. South African Journal of Psychology, 43(3), 356-369.

Van Dierendonck, D., Schaufeli, W. B., \& Buunk, B. P. (1998). The evaluation of an individual burnout intervention program: The role of inequity and social support. Journal of Applied Psychology, 83(3), 392-407.

Vroom, V. H. (1964). Work and motivation. Oxford, England: Wiley.

Waiganjo, E. W. (2012). Effect of human resource management practices on psychological contract in organizations. International Journal of Business and Social Science, 3(19), 117-122.

Wall, T. D., \& Wood, S. J. (2005). The romance of human resource management and business performance, and the case for big science. Human Relations, 58(4), 429-462.

Wang, M., \& Takeuchi, R. (2007). The role of goal orientation during expatriation: A cross-sectional and longitudinal investigation. Journal of Applied Psychology, 92(5), $1437-1445$.

Waxin, M. F., \& Panaccio, A. (2005). Cross-cultural training to facilitate expatriate adjustment: It works!. Personnel Review, 34(1), 51-67.

Weick, K. E. (1979). Cognitive processes in organizations. Research in Organizational Behavior, 1(1), 41-74.

Weissman, D., \& Furnham, A. (1987). The expectations and experiences of a sojourning temporary resident abroad: A preliminary study. Human Relations, 40(5), 313-326.

Welch, D. E. (2003). Globalisation of staff movements: Beyond cultural adjustment. Management International Review, 43(2), 149-169.

Welch, D. E., Welch, L. S., \& Worm, V. (2007). The international business traveller: A neglected but strategic human resource. The International Journal of Human Resource Management, 18(2), 173-183.

Welch, D. E., \& Worm, V. (2006). International business travellers: A challenge for IHRM. In G. Stahl, \& I. Björkman (Eds.), Handbook of Research in International Human Resource Management (pp. 283-301). Cheltenham, England: Edward Elgar. 
Welch, D. E., Worm, V., \& Fenwick, M. (2003). Are virtual international assignments feasible? Management International Review, 43(1), 95-114.

Westwood, R., Sparrow, P., \& Leung, A. (2001). Challenges to the psychological contract in Hong Kong. International Journal of Human Resource Management, 12(4), 621-651.

Wu, C. M., \& Chen, T. J. (2015). Psychological contract fulfillment in the hotel workplace: Empowering leadership, knowledge exchange, and service performance. International Journal of Hospitality Management, 48, 27-38.

Yan, A., Zhu, G., \& Hall, D. T. (2002). International assignments for career building: A model of agency relationships and psychological contracts. Academy of Management Review, 27(3), 373-391.

Youssef, C. M., \& Luthans, F. (2007). Positive organizational behavior in the workplace: The impact of hope, optimism, and resilience. Journal of Management, 33(5), 774-800.

Zakaria, N. (2000). The effects of cross-cultural training on the acculturation process of the global workforce. International Journal of Manpower, 21(6), 492-510.

Zhao, H. A. O., Wayne, S. J., Glibkowski, B. C., \& Bravo, J. (2007). The impact of psychological contract breach on work- related outcomes: A meta- analysis. Personnel Psychology, 60(3), 647-680.

Zhao, J., \& Chen, L. (2008). Individualism, collectivism, selected personality traits, and psychological contract in employment: A comparative study. Management Research News, 31(4), 289-304. 


\section{APPENDICES}

Appendix 1.

\section{Questionnaire 1}

\section{Part A: Psychological Contract Violation}

1. Indicate the degree of importance of each aspect of expatriation (1=Not important; $10=$ Extremely important).

\begin{tabular}{|c|l|l|l|l|l|l|l|l|l|l|l|}
\hline \multicolumn{2}{|l|}{} & 1 & 2 & 3 & 4 & 5 & 6 & 7 & 8 & 9 & 10 \\
\hline $\mathrm{a}$ & Salary & & & & & & & & & & \\
\hline $\mathrm{b}$ & Pay raises & & & & & & & & & & \\
\hline $\mathrm{c}$ & Bonuses & & & & & & & & & & \\
\hline $\mathrm{d}$ & Training & & & & & & & & & \\
\hline e & Advancement opportunities within an organization & & & & & & & & & & \\
\hline f & Career development within an organization & & & & & & & & & & \\
\hline g & Overall benefits & & & & & & & & & & \\
\hline h & Retirement benefits & & & & & & & & & & \\
\hline i & Health care benefits & & & & & & & & & & \\
\hline j & Decision-making input & & & & & & & & & & \\
\hline k & Job responsibility & & & & & & & & & & \\
\hline l Job challenge & & & & & & & & & & \\
\hline $\mathrm{m}$ & Feedback on job performance & & & & & & & & & & \\
\hline $\mathrm{n}$ & Supervisory support & & & & & & & & & & \\
\hline $\mathrm{o}$ & Organizational support & & & & & & & & & & \\
\hline $\mathrm{p}$ & Job security & & & & & & & & & & \\
\hline
\end{tabular}

2. Indicate how the amount of each aspect of expatriation you had actually received compared to the amount that the organization had committed to provide you ($2=$ Received much less than promised; $-1=$ Received less than promised; $0=$ Received as promised; $+1=$ Received more than promised; $+2=$ Received much more than promised).

\begin{tabular}{|c|l|l|l|l|l|l|}
\hline \multicolumn{2}{|l|}{-2} & -1 & 0 & 1 & 2 \\
\hline a & Salary & & & & & \\
\hline b & Pay raises & & & & & \\
\hline c & Bonuses & & & & & \\
\hline d & Training & & & & & \\
\hline e & Advancement opportunities within an organization & & & & & \\
\hline f & Career development within an organization & & & & \\
\hline g & Overall benefits & & & & & \\
\hline h & Retirement benefits & & & & & \\
\hline i & Health care benefits & & & & \\
\hline
\end{tabular}




\begin{tabular}{|c|l|c|c|c|c|c|}
\hline $\mathrm{j}$ & Decision-making input & & & & & \\
\hline $\mathrm{k}$ & Job responsibility & & & & \\
\hline $\mathrm{l}$ & Job challenge & & & & & \\
\hline $\mathrm{m}$ & Feedback on job performance & & & & & \\
\hline $\mathrm{n}$ & Supervisory support & & & & \\
\hline $\mathrm{o}$ & Organizational support & & & & & \\
\hline $\mathrm{p}$ & Job security & & & & \\
\hline
\end{tabular}

3. Indicate how well, overall, your employer has fulfilled the obligations that were promised to you ( $1=$ Very poorly fulfilled; $2=$ Poorly fulfilled; $3=$ Neutral; $4=$ Well fulfilled; 5= Very well fulfilled).

4. Has or had your employer ever failed to meet the obligation(s) that were promised to you?

a. Yes

b. No

\section{Part B: Cultural Intelligence}

1. Below are 10 statements about one's experience when interacting with people from other cultures. Please indicate to what extent each of the following statements describes you (1=Not at all; $2=$ A little; $3=$ Somewhat; $4=A$ lot; 5=Extremely well).

\begin{tabular}{|c|c|c|c|c|c|c|}
\hline & & 1 & 2 & 3 & 4 & 5 \\
\hline \multicolumn{7}{|c|}{ A. Cultural Knowledge } \\
\hline $\mathrm{a}$ & $\begin{array}{l}\text { I know the ways in which cultures around the world are } \\
\text { different. }\end{array}$ & & & & & \\
\hline $\mathrm{b}$ & $\begin{array}{l}\text { I can give examples of cultural differences from my } \\
\text { personal experience, reading, and so on. }\end{array}$ & & & & & \\
\hline \multicolumn{7}{|c|}{ B. Cultural Skills } \\
\hline $\mathrm{a}$ & I enjoy talking with people from different cultures. & & & & & \\
\hline $\mathrm{b}$ & $\begin{array}{l}\text { I have the ability to accurately understand the feelings of } \\
\text { people from other cultures. }\end{array}$ & & & & & \\
\hline $\mathrm{c}$ & $\begin{array}{l}\text { I sometimes try to understand people from another culture } \\
\text { by imagining how something looks from their perspective. }\end{array}$ & & & & & \\
\hline $\mathrm{d}$ & $\begin{array}{l}\text { I can change my behavior to suit different cultural } \\
\text { situations and people. }\end{array}$ & & & & & \\
\hline $\mathrm{e}$ & $\begin{array}{l}\text { I accept delays without becoming upset when in different } \\
\text { cultural situations and with culturally different people. }\end{array}$ & & & & & \\
\hline \multicolumn{7}{|c|}{ C. Cultural Metacognition } \\
\hline $\mathrm{a}$ & $\begin{array}{l}\text { I am aware of the cultural knowledge I use when } \\
\text { interacting with someone from another culture. }\end{array}$ & & & & & \\
\hline $\mathrm{b}$ & $\begin{array}{l}\text { I think a lot about the influence that culture has on my } \\
\text { behavior and that of others who are culturally different. }\end{array}$ & & & & & \\
\hline $\mathrm{c}$ & $\begin{array}{l}\text { I am aware that I need to plan my course of action when in } \\
\text { different cultural situations and with culturally different }\end{array}$ & & & & & \\
\hline
\end{tabular}


people.

\section{Part C: Personal Profile}

Please check the appropriate box.

1. What is your gender?
a) Male
b) Female

2. What is your age range?
a) Under 20 years old
b) 20 - 30 years old
c) $31-40$ years old
d) $41-50$ years old
e) 51-60 years old
f) 61 years old or more

3. What is the highest degree or level of school you have completed? If currently enrolled, highest degree received.
a) High school graduate (e.g., High school diploma or the equivalent)
b) Bachelor's degree (e.g., BA, AB, BS)
c) Master's degree (e.g., MA, MS, MEng, MEd, MSW, MBA)
d) Doctorate degree (e.g., $\mathrm{PhD}, \mathrm{EdD}$ )
e) Professional degree (e.g., MD, DDS, DVM, LLB, JD)

4-1. What is your marital status?
a) Single, never married
b) Married
c) Unmarried, but cohabiting partner
d) Divorced, widowed, or separated

(If you selected "b. Married" or "c. Unmarried, but cohabiting partner" above, and if you are accompanied by your spouse or partner on your current international assignment)

4-2. How satisfied is your spouse or partner with the overall life in the host country?
a) Very dissatisfied
b) Dissatisfied
c) Neither satisfied nor dissatisfied
d) Satisfied
e) Very satisfied

5. What is your nationality?
a) American
b) Korean
c) Other 
6. What is your native language?
a) English
b) Korean
c) Other

7. Where is your company headquarter located?
a) America
b) Korea
c) Other

8. Please specify the country in which you are currently working. Country

9. How well do you speak and understand the host country language?
a) Not at all
b) Some understanding
c) Fair
d) Reasonably fluent
e) Fluent

10. Please indicate how similar or different the culture of the current host country is from your home country culture.
a) Very different
b) Different
c) Neither similar nor different
d) Similar
e) Very similar

11-1. Have you received any cross- cultural training in your current international assignment? (e.g., language training and intercultural training)
a) Yes, I have
b) No, I have not

\section{(If you selected "a. Yes, I have" above)}

11-2. When was the cross-cultural training carried out?
a) Before the international assignment begins
b) During the international assignment
c) Both before and during the international assignment

\section{(If you selected "a. Yes, I have" to Question 11-1)}

11-3. Please indicate the extent to which cultural training is provided.
a) To a very little extent
b) To a little extent
c) To some extent
d) To a great extent
e) To a very great extent 
12. Which of the following job titles best describes your current position?
a) Intern
b) Entry level employee
c) Manager/Supervisor
d) Executive

13. How long have you been working in the current company?
a) Less than 1 year
b) $1-3$ years
c) $4-7$ years
d) $8-15$ years
e) More than 15 years

14. Please specify duration of your current international assignment in years.
a) Less than 1 year
b) $1-2$ years
c) $3-5$ years
d) More than 5 years

15. What is the total number of years of experience you had working in a foreign country prior to the current assignment?
a) No experience
b) Less than 1 year
c) $1-2$ years
d) $3-5$ years
e) More than 5 years

16. Which of the following best describes your company's primary industry?
a) Accounting/business/finance service
b) Communication/education service
c) Food/daily products
d) Game
e) General industrial machines and equipments
f) Retail/whole sale
g) Other 
Appendix 2.

Questionnaire 2 (Time 2)

\section{Part D: Trust}

1. Please indicate the degree of your agreement or disagreement with each statement (1=Strongly disagree; $2=$ Disagree; $3=$ Neither agree nor disagree; $4=$ Agree; $5=$ Strongly agree).

\begin{tabular}{|c|c|c|c|c|c|c|}
\hline & & 1 & 2 & 3 & 4 & 5 \\
\hline $\mathrm{a}$ & I am sure I fully trust my employer. & & & & & \\
\hline $\mathrm{b}$ & My employer is open and upfront with me. & & & & & \\
\hline $\mathrm{c}$ & I believe my employer has high integrity. & & & & & \\
\hline $\mathrm{d}$ & $\begin{array}{l}\text { In general, I believe my employer's motives and intentions } \\
\text { are good. }\end{array}$ & & & & & \\
\hline $\mathrm{e}$ & My employer is always honest and truthful. & & & & & \\
\hline $\mathrm{f}$ & I think my employer treats me fairly. & & & & & \\
\hline $\mathrm{g}$ & $\begin{array}{l}\text { I can expect my employer to treat me in a consistent and } \\
\text { predictable fashion. }\end{array}$ & & & & & \\
\hline
\end{tabular}

\section{Part E: Job Satisfaction}

1. Please indicate the degree of your agreement or disagreement with each statement ( $1=$ Strongly disagree; $2=$ Disagree; $3=$ Neither agree not disagreed; $4=$ Agree; $5=$ Strongly agree).

\begin{tabular}{|c|l|l|l|l|l|l|}
\hline \multicolumn{2}{|l|}{} & 1 & 2 & 3 & 4 & 5 \\
\hline a & I am seldom bored with my international assignment. & & & & & \\
\hline b & $\begin{array}{l}\text { I feel fairly well satisfied with my present international } \\
\text { assignment. }\end{array}$ & & & & \\
\hline c & I am satisfied with my job for the time being. & & & & & \\
\hline d & $\begin{array}{l}\text { Most days I am enthusiastic about my international } \\
\text { assignment. }\end{array}$ & & & \\
\hline e & $\begin{array}{l}\text { I like my international assignment better than the average } \\
\text { Worker does. }\end{array}$ & & & & \\
\hline f & I find real enjoyment in my international assignment. & & & & & \\
\hline
\end{tabular}




\section{Part F: Organizational Commitment}

1. Please indicate the degree of your agreement or disagreement with each statement $(1=$ Strongly disagree; $2=$ Disagree; $3=$ Neither agree nor disagree; $4=$ Agree; $5=$ Strongly agree).

\begin{tabular}{|c|l|l|l|l|l|l|}
\hline \multicolumn{2}{|l|}{} & 1 & 2 & 3 & 4 & 5 \\
\hline a & $\begin{array}{l}\text { I would be very happy to spend the rest of my career with } \\
\text { this organization. }\end{array}$ & & & & \\
\hline b & $\begin{array}{l}\text { I enjoy discussing about my organization with people } \\
\text { outside it. }\end{array}$ & & & & \\
\hline c & I really feel as if this organization's problems are my own. & & & & & \\
\hline d & $\begin{array}{l}\text { I do not think that I could easily become as attached to } \\
\text { another organization as I am to this one. }\end{array}$ & & & & \\
\hline e & I feel like 'part of the family' at my organization. & & & & \\
\hline f & I feel ‘emotionally attached' to this organization. & & & & \\
\hline g & $\begin{array}{l}\text { This organization has a great deal of personal meaning for } \\
\text { me. }\end{array}$ & & & & \\
\hline h & I feel a 'strong' sense of belonging to my organization. & & & & & \\
\hline
\end{tabular}

\section{Part G: Desire to Terminate the Assignment}

1. Please indicate the extent of your desire to terminate the assignment ( $1=$ Definitely no; $2=$ No; $3=$ Neither yes nor no; $4=$ Yes; $5=$ Definitely yes).

\begin{tabular}{|c|l|l|l|l|l|l|}
\hline \multicolumn{2}{|c|}{} & 1 & 2 & 3 & 4 & 5 \\
\hline a & $\begin{array}{l}\text { Would you like to terminate this expatriate assignment } \\
\text { early? }\end{array}$ & & & & & \\
\hline b & Do you hope that you will be asked to return home early? & & & & & \\
\hline c & $\begin{array}{l}\text { If this assignment had no impact on your career, would you } \\
\text { terminate the assignment now? }\end{array}$ & & & & \\
\hline d & $\begin{array}{l}\text { Would you have rejected this expatriate assignment if you } \\
\text { knew what you were getting yourself into? }\end{array}$ & & & & \\
\hline
\end{tabular}

\section{Part H: Expatriate Performance}

1. Please indicate your performance $(1=$ Unsatisfactory or poor; $2=$ Not very good or below average; $3=$ Moderate or average; $4=$ Very good or above average; $5=$ Exceptional or outstanding).

\begin{tabular}{|c|c|c|c|c|c|c|}
\hline \multirow{2}{*}{\multicolumn{7}{|c|}{ A. Contextual/Managerial Performance }} \\
\hline & & & & & & \\
\hline $\mathrm{a}$ & $\begin{array}{l}\text { Your ability to foster organizational commitment in the } \\
\text { foreign subsidiary }\end{array}$ & & & & & \\
\hline $\mathrm{b}$ & Your effectiveness at representing the XXX company to & & & & & \\
\hline
\end{tabular}




\begin{tabular}{|c|l|l|l|l|l|l|}
\hline & host national customers and community & & & & \\
\hline $\mathrm{c}$ & $\begin{array}{l}\text { Your effectiveness at maintaining good working } \\
\text { relationships with host nationals }\end{array}$ & & & & \\
\hline $\mathrm{d}$ & $\begin{array}{l}\text { Your effectiveness at supervising and developing host } \\
\text { national subordinates }\end{array}$ & & & & \\
\hline & $\begin{array}{l}\text { B. Expatriate-specific Performance } \\
\text { a }\end{array}$ & $\begin{array}{l}\text { Your effectiveness at training your expatriate or host } \\
\text { national replacement }\end{array}$ & & & \\
\hline b & $\begin{array}{l}\text { Your effectiveness at transferring information across } \\
\text { strategic units (e.g., from the host country to headquarters) }\end{array}$ & & & & \\
\hline $\mathrm{c}$ & $\begin{array}{l}\text { Your interpersonal relationships with host nationals, in } \\
\text { general }\end{array}$ & & & & \\
\hline d & Your ability to speak the host national language & & & \\
\hline
\end{tabular}

\section{Part I: Personality}

1. Please indicate the extent to which you agree or disagree with that statement. You should rate the extent to which the pair of traits applies to you, even if one characteristic applies more strongly than the other $(1=$ Strongly disagree; $2=$ Disagree; $3=$ Somewhat disagree; $4=$ Neither agree not disagree; $5=$ Somewhat agree; $6=$ Agree; $7=$ Strongly agree).

\begin{tabular}{|c|l|l|l|l|l|l|l|l|}
\hline \multicolumn{2}{|l|}{} & 1 & 2 & 3 & 4 & 5 & 6 & 7 \\
\hline \multicolumn{2}{|l|}{ I see myself as: } & & & & & & & \\
\hline a & Extraverted, enthusiastic. & & & & & & & \\
\hline b & Critical, quarrelsome. & & & & & & & \\
\hline c & Dependable, self-disciplined. & & & & & & & \\
\hline d & Anxious, easily upset. & & & & & & & \\
\hline e & Open to new experiences, complex. & & & & & & & \\
\hline f & Reserved, quiet. & & & & & & & \\
\hline g & Sympathetic, warm. & & & & & & & \\
\hline h & Disorganized, careless. & & & & & & & \\
\hline i & Calm, emotionally stable. & & & & & & & \\
\hline j & Conventional, uncreative. &
\end{tabular}


VITA

\section{KOWOON KIM}

2006-2011

B.S., International Trade

Dongguk University

Seoul, South Korea

2009-2010

Exchange Program

University of Utah

Saltlake, Utah

2012-2014

M.S., International Management Studies

University of Texas at Dallas

Dallas, Texas

2014-2018

Doctor of Business Administration (DBA) Candidate

Florida International University

Miami, Florida

\section{PUBLICATIONS AND PRESENTATIONS}

Kim, K., \& Von Glinow, M. A. (2017). Managing non-traditional human capital in international assignments: A qualitative analysis of the talent and innovation gaps. In S. K. Kundu, \& S. Munjal (Eds.), Human Capital and Innovation (pp. 91-129). London, England: Palgrave Macmillan.

Kim, K., \& Von Glinow, M. A. (2017). Contextual Determinants in Disclosing One's Stigmatized Identity During Expatriation: The Case of Lesbian and Gay Self-Initiated Expatriates. Journal of Global Mobility, 5(3), 317-338.

Kim, K., Halliday, C. S., Zhao, Y., Wang, C., \& Von Glinow, M. A. (2018). Rewarding Self- Initiated Expatriates: A Skills- Based Approach. Thunderbird International

Business Review, 60(1), 89-104. 